\title{
Metodika adaptace malých a středních podniků v sektoru služeb na implementaci principů, postupů, metod a nástrojů Společnosti 4.0
}

Lilia Dvoráková • Jiř̌́ Vacek • Marie Černá • Pavlína Hejduková Jana Hinke • Petra Taušl Procházková • Lucie Vallišová Jakub Horák • Zdeněk Caha • Veronika Machová

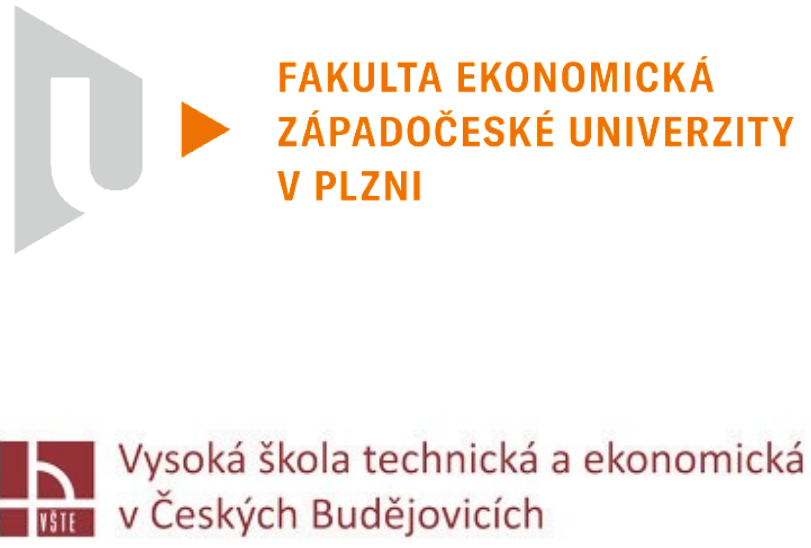

červen 2020 


\section{Autorský kolektiv}

prof. Ing. Lilia Dvořáková, CSc.

doc. Ing. Jiří Vacek, Ph.D.

Ing. Marie Černá, Ph.D.

Ing. Pavlína Hejduková, Ph.D,

Doc. Ing. Jana Hinke, Ph.D.

Doc. Ing. Petra Taušl Procházková, Ph.D.

Ing. Lucie Vallišová, Ph.D.

PaedDr. Mgr. Zdeněk Caha, Ph.D., MBA, MSc.

Ing. Jakub Horák

Ing. Veronika Machová, MBA vedoucí autorského kolektivu, kapitoly A, B, D, F, H, I, J

subkapitoly B.1, B.2, B.4, C.1, C.2, kapitola $\mathrm{K}$

subkapitoly B.2, C.2, kapitoly E, G subkapitoly B.4, C.3

subkapitoly C.4, C.5, kapitola $\mathrm{K}$ subkapitoly B.1, C.3 subkapitoly B.2, C.2, kapitoly E, G subkapitoly B.3, C.6 subkapitoly B.3, C.6 subkapitoly B.3, C.6

\section{Recenzenti}

Doc. Ing. Pavel Kopeček, CSc., Ing. Monika Březinová, Ph.D.

\section{Jazyková a typografická korektura}

Mgr. Milada Peštová

Vydala Západočeská univerzita v Plzni, Fakulta ekonomická, a Vysoká škola technická a ekonomická v Českých Budějovicích

https://azis.zcu.cz

Počet stran: 85

První vydání, Plzeň 2020

(C) Lilia Dvořáková, Jiří Vacek, Marie Černá, Pavlína Hejduková, Jana Hinke, Petra Taušl Procházková, Lucie Vallišová, Zdeněk Caha, Jakub Horák, Veronika Machová, 2020

ISBN 978-80-261-0953-2

DOI https://doi.org/10.24132/ZCU.2020.09532

$\mathbf{T} \quad \mathbf{A}$ C $\mathbf{R}$

Tato publikace byla vytvořena se státní podporou Technologické agentury ČR v rámci Programu ÉTA 


\section{OBSAH}

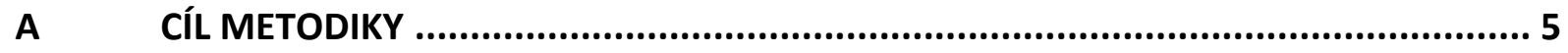

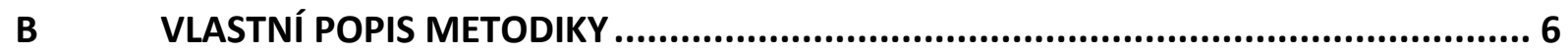

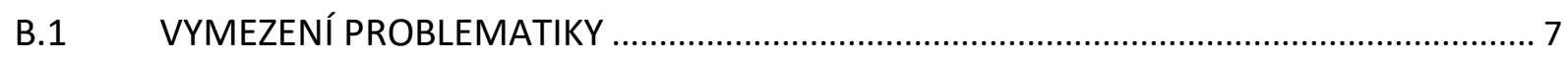

B.1.1 Studie 1 - Identifikace, analýza a hodnocení principů, postupů, metod a nástrojů pro adaptaci sektoru služeb na technické, ekonomické, sociální a environmentální podmínky Společnosti 4.0 .

B.1.2 Studie 2 - Katalog změn znalostních a dovednostních kvalifikačních požadavků na zaměstnanecké pozice v souvislosti s nástupem a rozvojem Společnosti 4.0

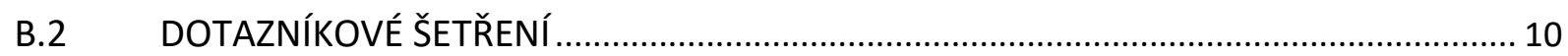

B.2.1 Výběr vzorku podniků pro dotazníkové šetření ......................................................... 10

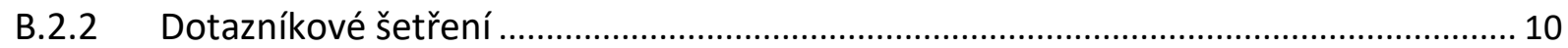

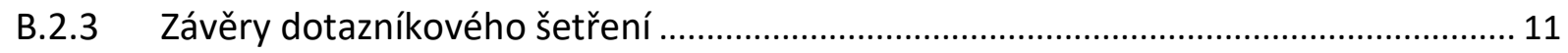

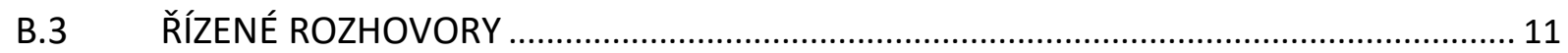

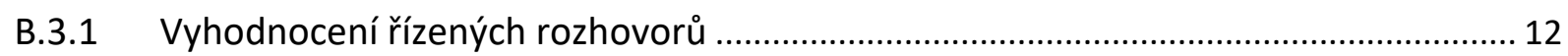

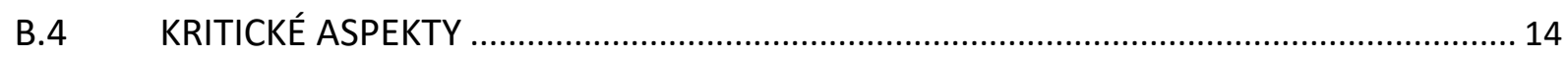

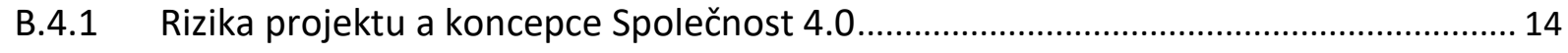

B.4.2 Příležitosti zavádění a využívání principů Společnosti 4.0........................................... 16

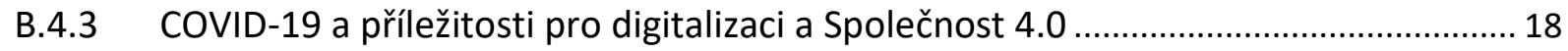

C KATALOG OPATŘENÍ PRO ADAPTACI MALÝCH A STŘEDNÍCH PODNIKŮ V SEKTORU SLUŽEB NA PODMIINKY SPOLEČNOSTI 4.0 ......................... 20

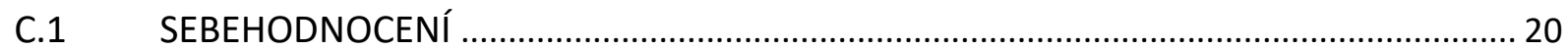

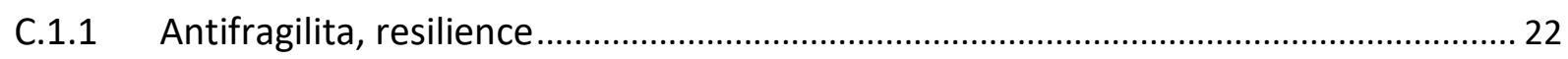

C.1.2 Adaptace firmy na podmínky Společnosti 4.0 .......................................................... 24

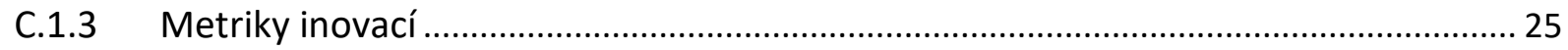

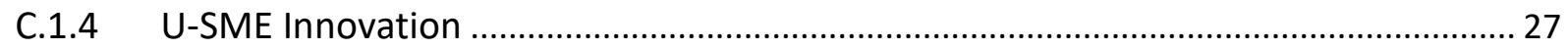

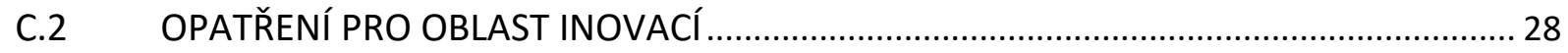

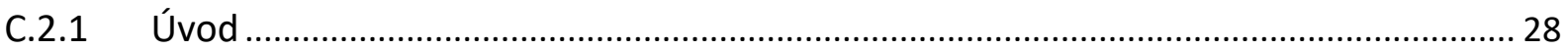

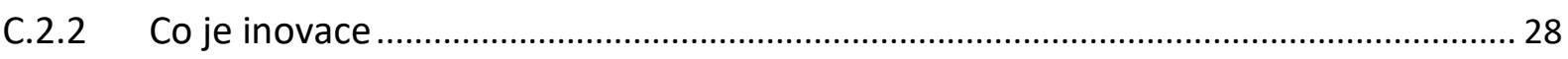

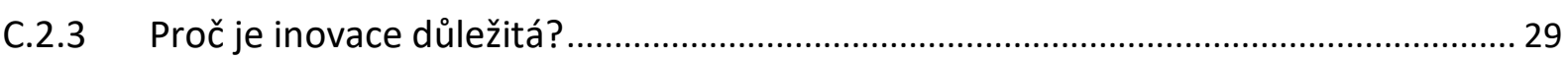

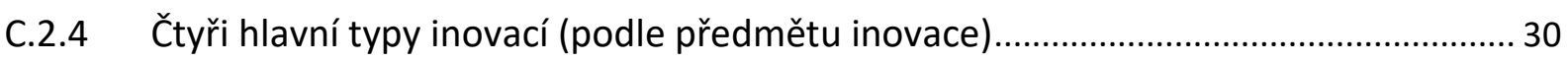

C.2.5 Př́růstková, radikální a přelomová inovace ................................................................ 30

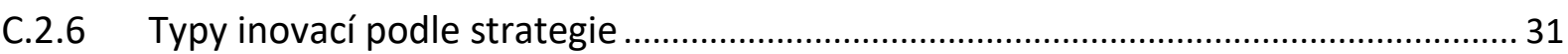




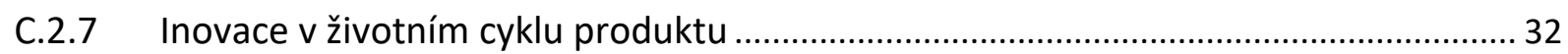

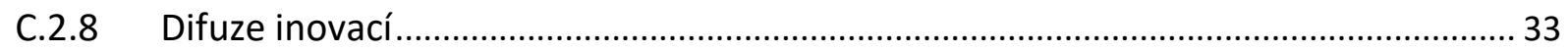

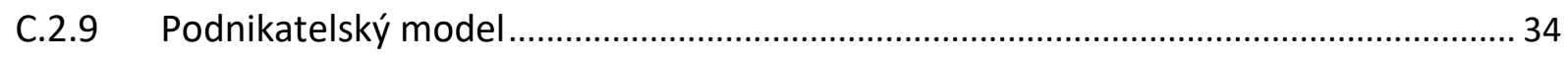

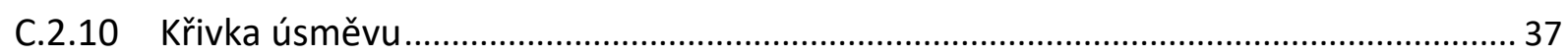

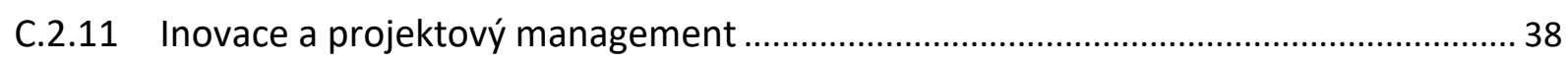

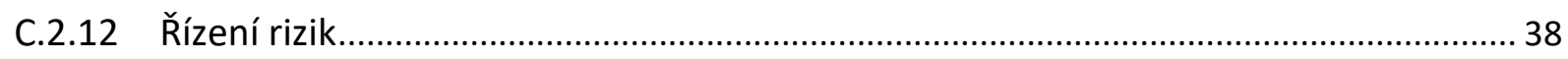

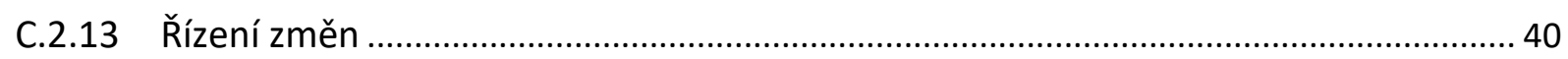

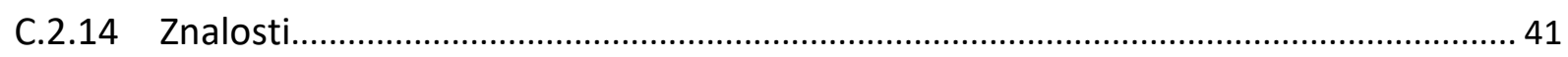

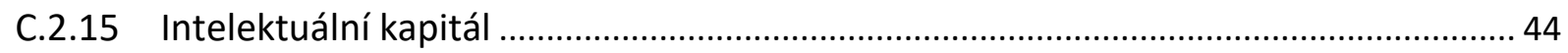

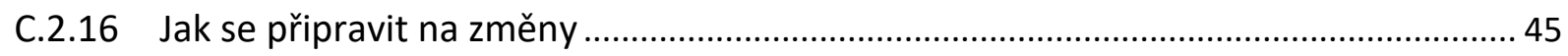

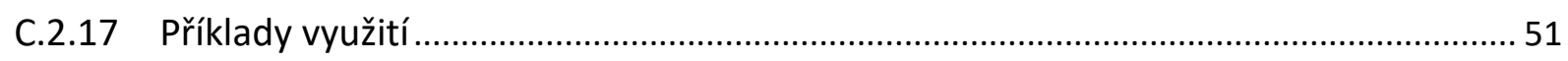

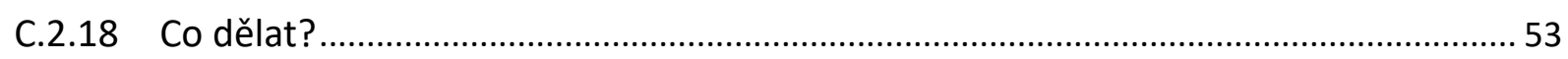

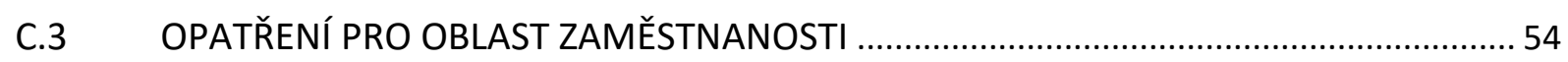

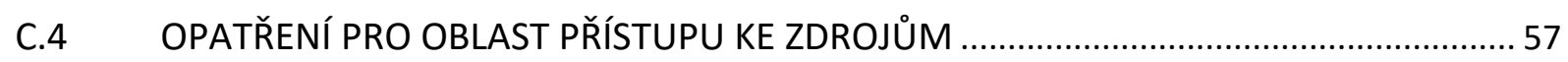

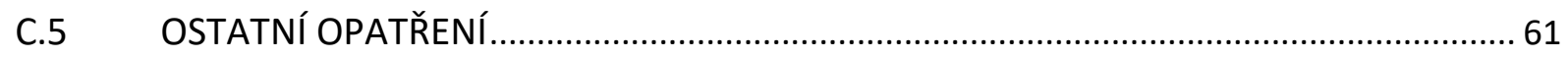

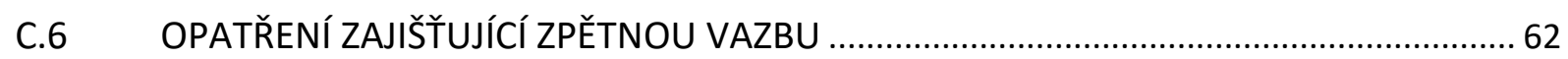

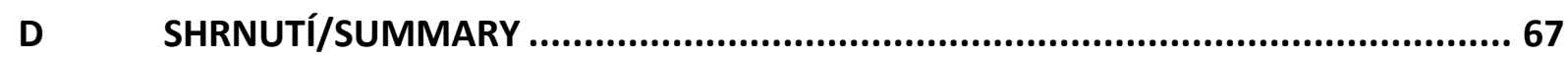

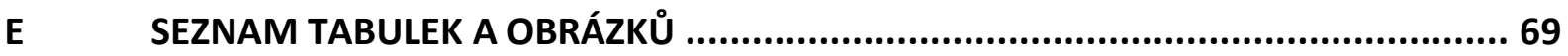

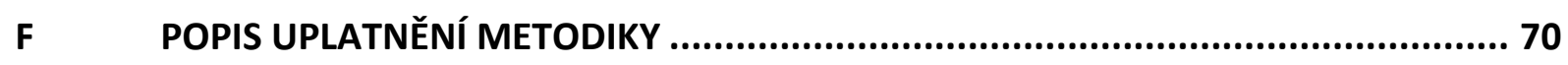

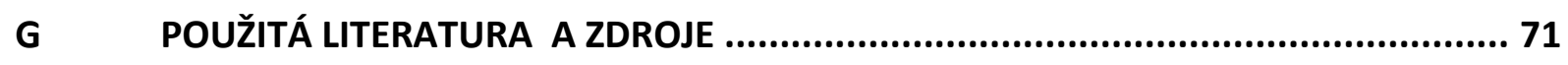

H SEZNAM AKTIVIT PŘEDCHÁZEJÍCÍCH METODICE ............................................. 77

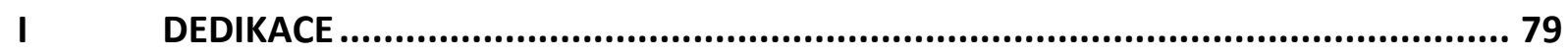

J PROHLÁŠENÍ PŘEDKLADATELE METODIKY ................................................ 80

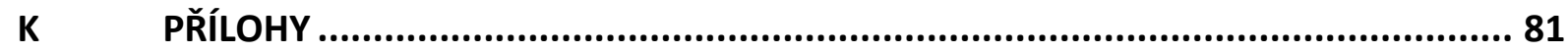




\section{A CÍl METODIKY}

Cílem zpracované metodiky je návrh postupu, resp. relevantních kroků pro adaptaci malých a středních podniků v oblasti služeb na disruptivní změny přinášející koncepce Průmyslu 4.0 a Společnosti 4.0 do podnikových procesů a do celé společnosti. Navržený postup a kroky mají umožnit realizovat a podpořit efektivní a včasnou adaptaci malých (včetně mikro) a středních podniků $v$ sektoru služeb na změny v podnikatelském prostředí s cílem zajistit udržitelný růst, nové konkurenční výhody, předcházení a eliminaci hrozeb a rizik vyplývajících z nepochopení nutnosti transformace současných a budoucích podnikových procesů.

Metodika adaptace malých a středních podniků v sektoru služeb na implementaci principů, postupů, metod a nástrojů Společnosti 4.0 (dále jen Metodika) vznikla za finanční podpory Technologické agentury ČR, programu Éta, jako plánovaný výstup projektu č. TL02000136 „Adaptace sektoru znalostně náročných služeb na podmínky Společnosti 4.0“ (https://azis.zcu.cz, 2019-2021).

Potřeba vytvořit komplexní postup adaptace malých a středních podniků v sektoru služeb na technické, ekonomické, sociální a environmentální podmínky Společnosti 4.0 vychází z poptávky a požadavků podnikové praxe, které byly mapovány před zahájením projektu a $v$ průběhu jeho realizace. Konkrétní požadavky na obsah Metodiky byly osobně diskutovány a identifikovány při řizených rozhovorech s vlastníky a manažery malých a středních podniků v sektoru služeb se specifickým zaměřením na malé a střední podniky $v$ sektoru znalostně náročných služeb. Významnou informační podporu a zpětnou vazbu při tvorbě Metodiky poskytli zástupci šesti externích aplikačních garantů - Krajská hospodářská komora v Plzeňském kraji; Úřad práce ČR, krajská pobočka v Plzni; Úřad práce ČR, krajská pobočka v Českých Budějovicích; Jihočeská hospodářská komora; Krajský úřad Jihočeského kraje; Jihočeská společnost pro rozvoj lidských zdrojů, o.p.s.

Metodika vychází z předchozích výstupů projektu v roce 2019 a 2020; studie 1 „Identifikace, analýza a hodnocení principů, postupů, metod a nástrojů pro adaptaci sektoru služeb na technické, ekonomické, sociální a environmentální podmínky Společnosti 4.0“ (Vacek a kol., 2019), dále studie 2 „Katalog změn znalostních a dovednostních kvalifikačních požadavků na zaměstnanecké pozice v souvislosti s nástupem a rozvojem Společnosti 4.0“ (Taušl Procházková a kol., 2019) a podnětů, připomínek a zpětných vazeb z realizovaného workshopu č. 1 a Zprávy z workshopu č. 1 „Adaptace sektoru znalostně náročných služeb na podmínky Společnosti 4.0 (Taušl Procházková, 2020).

Jsme si vědomi rychlého rozvoje a změn v řetězci Průmysl 4.0 - Práce 4.0 - Vzdělání 4.0 - Společnost 4.0 $\checkmark$ národním a celosvětovém kontextu a diskontinuálních podmínek v podnikové praxi. Multioborový autorský tým Metodiky složený z akademických pracovníků Fakulty ekonomické Západočeské univerzity v Plzni a Vysoké školy technické a ekonomické vČeských Budějovicích uvítá další připomínky, návrhy a doporučení k Metodice, která byla zpracována v roce 2020. Pro tento účel, prosím, využijte e-mailovou adresu: Idvorako@kfu.zcu.cz.

Za autorský tým Metodiky

Lilia Dvořáková

hlavní řešitel projektu TA ČR 


\section{B VLASTNÍ POPIS METODIKY}

Metodika v částech B, B.1, B.2, B.3, B.4 navrhuje postup vedoucí k identifikaci, analýze a hodnocení potenciálu, př́ležitostí a rizik, která souvisejí s automatizací, robotizací, elektronizací, digitalizací podnikových procesů $v$ malých a středních podnicích (dále jen MSP), se změnami požadavků na pracovní sílu včetně změn obsahu celoživotního vzdělávání a se změnami organizace a forem práce. Dále metodika navrhuje v částech C, C.1, C.2, C.3, C.4, C.5, C.6 opatření pro oblast inovací, opatření pro oblast zaměstnanosti a opatření pro oblast př́stupu ke zdrojům včetně opatření zajišt́ujících zpětnou vazbu.

V rámci výzkumu vedoucího $\mathrm{k}$ tvorbě Metodiky byly využity kvalitativní a kvantitativní metody výzkumu kombinující metody desk research a empirické získávání dat (dotazníkové šetření a řízené rozhovory). Komparativní metody byly využity při porovnání řešené problematiky $v$ českém a zahraničním prostředí. $V$ této části výzkumu byla využita sekundární agregovaná data (mezinárodní a české přehledy) a primární data externích aplikačních garantů projektu zabývajících se prací s malými a středními podniky v sektoru služeb.

$\checkmark$ rámci přípravy a realizace empirického šetření byla využita spolupráce s externími aplikačními garanty projektu, databáze Albertina společnosti Bisnode a databáze Technologické agentury ČR o podpořených projektech zaměřených do oblasti Průmyslu 4.0 a Společnosti 4.0. Empirická šetření byla zaměřena zejména na zjištování postojů malých a středních podniků $k$ inovacím souvisejícím s nástupem technologických, ekonomických a sociálních změn vyvolaných Průmyslem 4.0 a Společností 4.0, dále na zjištění současného stavu a strategie $v$ této oblasti $v$ prostředí MSP v sektoru služeb a na bariéry a limity rozvoje MSP v sektoru služeb. Dotazníkového šetření se zúčastnilo 141 respondentů a do ř́zených rozhovorů se zapojilo 20 zástupců podniků ze sektoru služeb.

$\checkmark$ rámci analýzy klíčových národních a evropských dokumentů, vztahujících se ke strategii a postupu realizace koncepce Průmyslu 4.0 a Společnosti 4.0, se řešitelský tým projektu zaměřil zejména na Akční plán pro Společnost 4.0 (Úřad vlády ČR, 2017a), Aliance Společnost 4.0 (Úřad vlády ČR, 2017b), Akční plán pro digitální vzdělávání EU (Evropská komise, 2018) a Strategie Evropa 2020 a ČR (Vláda ČR, 2010).

\section{Vymezení základních pojmů}

Průmysl 4.0 - Společnost 4.0: digitalizace, robotizace a automatizace většiny současných lidských činností pro zajištění větší rychlosti a efektivity tvorby presnějších, spolehlivějších a levnějších produktů a služeb, pro efektivnější využití materiálů a pro ekolologičtější výrobní a nevýrobní procesy ve všech odvětvích národního hospodářství, v domácnostech a v lidském životě.

Znalostně intenzivní služby: služby s velkou intenzitou využívání znalostí. Rozvíjejí se rychleji než jiné sektory ekonomiky, roste jejich podíl na tvorbě hodnot a zaměstnanosti. Roste jejich význam jako zdroje znalostí a kanálů pro jejich difuzi. Jejich výkonnost ovlivňuje výkonnost jejich klientů a tím i dynamiku celé ekonomiky. Primárně nevytvářejí výrobky a zboží, ale přispívají ke zvýšení jejich hodnoty. Informační hodnota služeb je často vyšší než samotného produktu. Znalostně intenzivní podnikové služby (KIBS - Knowledge Intensive Business Services) jsou často považovány za charakteristický znak znalostní ekonomiky. Do tohoto sektoru patří firmy, které pomáhají jiným vypořádat se s problémy, pro jejichž řešení jsou potřebné externí zdroje znalostí. V klasifikaci NACE jim odpovídají sekce J - informační a komunikační aktivity, a $\mathrm{M}$ - profesionální, vědecké a technické aktivity. 
Aktivní politika zaměstnanosti (APZ): souhrn opatření směřujících $k$ zajištění maximálně možné úrovně zaměstnanosti. Aktivní politiku zaměstnanosti zabezpečuje Ministerstvo práce a sociálních věcí ČR a Úřad práce ČR a jeho pobočky; podle situace na trhu práce spolupracují při její realizaci s dalšími subjekty. Mezi nástroje APZ patří např́iklad rekvalifikace, investiční pobídky, příspěvek na zapracování a mnohé jiné.

Business Angel: investor, jenž využívá vlastní kapitál k financování či spolufinancování malých a středních podniků s perspektivou růstu za účelem zhodnocení svých vkladů.

Digitalizace: proces zavádění digitálních technologií a jejich využívání $v$ nejrůznějších oblastech výroby i života společnosti. Zefektivňuje a zlepšuje fungování procesů a služeb.

Digitální gramotnost: soubor digitálních kompetencí (vědomostí, dovedností, postojů, hodnot), které jedinec potřebuje $\mathrm{k}$ bezpečnému, sebejistému, kritickému a tvořivému využívání digitálních technologií při práci, při učení, ve volném čase i při svém zapojení do společenského života.

Dotace: peněžitá úhrada poskytnutá orgánem státní správy nebo územním samosprávným celkem k předem známému účelu, který je ve veřejném zájmu.

Dovednost: učením a praxí získaná dispozice ke správnému, kvalitnímu, rychlému a úspornému vykonávání určité činnosti vhodnou metodou.

Rekvalifikace: změna nebo rozšíření stávající kvalifikace a to včetně jejího udržování nebo obnovování.

Startup: nově založená společnost, která na základě inovativního přístupu vyvíjí (místně či časově) unikátní produkt či službu.

Rizikový (venture) kapitál: kapitál investovaný do rozvoje podniku na základě kvalitního podnikatelského plánu. Investor od vstupu do podniku očekává především rychlý růst jeho hodnoty.

Trh práce: označuje pomysIný prostor, kde dochází ke střetu nabídky pracovních sil, tedy lidí, jejich schopností, předpokladů, dovedností a kvalifikace a poptávky ze strany zaměstnavatelů.

\section{B.1 VYMEZENÍ PROBLEMATIKY}

V první fázi projektu se řešitelský tým zabýval analýzou současného stavu vycházející z literární rešerše (desk research - studie 1 a 2) a terénního výzkumu (field research - dotazníkové šetření a strukturované rozhovory). Výsledky a výstupy této fáze jsou stručně popsány v následujících částech této kapitoly.

\section{B.1.1 Studie 1 - Identifikace, analýza a hodnocení principů, postupů, metod a nástrojů pro adaptaci sektoru služeb na technické, ekonomické, sociální a environmentální podmínky Společnosti 4.0}

Tato studie je jedním z výchozích podkladů pro vypracování metodiky adaptace znalostně intenzivních služeb. Vychází především z "výzkumu od stolu“. Jejím cílem byla identifikace relevantních zdrojů informací a znalostí a shrnutí získaných poznatků ve formě podkladu k diskusi $s$ aplikačními garanty a vybranými podniky, identifikovanými v dotazníkovém šetření (viz subkap. B.2). Jednotlivé kapitoly této studie se soustřed'ují na vybrané aspekty:

\section{Výchozí stav, trendy}

Současný stav a trendy $v$ sektoru služeb, z toho speciálně znalostně intenzivních: podíl na ekonomice a zaměstnanosti, vazby na regionální, národní a evropské rozvojové strategie. 


\section{Klasifikace znalostně intenzivních služeb}

Vycházíme zde z taxonomie $\mathrm{OECD}$ a dalších literárních zdrojů. Kapitolu uzavírá popis souvislostí znalostních služeb a inovací s krátkým úvodem do konceptu otevřených inovací.

\section{Cesta od Průmyslu 4.0 ke Společnosti 4.0 a Společnosti $\mathbf{5 . 0}$}

Tato kapitola se soustředí na širší rámec čtvrté průmyslové revoluce - řetězec, který může začínat Průmyslem 4.0, ale musí přes pojetí Práce 4.0 , Vzdělávání 4.0 vyústit v rámcové, systémové pojetí Společnosti 4.0 s výhledem na další etapu - Společnost 5.0.

\section{Znalostně intenzivní služby jako podpora kvality života}

Ekonomické ukazatele dokážou hodnotit pouze jednu část kvality života, velkou roli v hodnocení kvality života mají subjektivní postoje jednotlivců. Znalostně intenzivní služby mohou podpořit zvýšení kvality života $v$ souvislosti $s$ novými trendy ve zdravotnictví, sociálních službách, zaměstnanosti a dalších oblastech.

\section{Principy, postupy, metody a nástroje pro adaptaci sektoru služeb}

Nastupující technologie mohou výrazně podpořit podnikání v sektoru služeb. Kombinací těchto technologií vznikají aplikace, které jsou schopnější než pouhý součet schopností jejich částí, vznikají synergické efekty a emergentní jevy. Vytvářejí nejen nové příležitosti, ale i rizika, rozvoj umělé inteligence vyvolává nové etické a právní otázky.

\section{Případové studie, príklady dobré praxe}

Vybrané př́padové studie by mohly být inspirací pro české MSP v sektoru znalostních služeb.

Řada firem pro své jádrové činnosti (specifikaci, návrh, vývoj a implementaci nových produktů) využívá svých vnitřních kapacit, ale vyhledává externí služby v oblasti strategie, financí a právních služeb. Spolupráce s externími poskytovateli služeb může přinést do firmy nový pohled a užitečné podněty zvenčí. Takto získané zkušenosti pak může firma využít $k$ dalšímu rozvoji svých vlastních kompetencí, svého růstu a konkurenceschopnosti. Podněty k inovacím často přicházejí od uživatelů.

Velkou přidanou hodnotu mohou vytvářet služby poskytované po dodání projektového produktu (údržba, upgrady apod.), v úvahu přichází i vzdálená preventivní diagnostika a údržba.

Pozornost je třeba věnovat měnícím se způsobům zaměstnání (gig ekonomika), nové přiležitosti vznikají v tzv. cirkulární ekonomice, která se stává jedním z prioritních témat EU. Přináší př́ležitost materiálové soběstačnosti, vytváří nová pracovní místa a otevírá prostor pro investice do udržitelných inovací.

\section{B.1.2 Studie 2 - Katalog změn znalostních a dovednostních kvalifikačních požadavků na zaměstnanecké pozice v souvislosti s nástupem a rozvojem Společnosti 4.0}

Studie 2 se zabývá problematikou změn týkajících se znalostních a dovednostních kvalifikačních požadavků na zaměstnanecké pozice ve Společnosti 4.0. Cílem studie bylo reflektovat změny, které nastaly a nastávají $v$ oblasti znalostních a dovednostních kvalifikačních požadavků kladené na zaměstnanecké pozice, a to právě v souvislosti s rozvojem Společnosti 4.0. Studie byla zpracována především formou literární rešerše relevantních zdrojů a dále byla upravena na základě zpětné vazby od externích aplikačních garantů/expertů pohybujících se v diskutované problematice. Závěry vycházející z této studie Ize považovat za stavební kámen pro další empirickou práci na výzkumném tématu. 
Text studie je sestaven logicky v návazných krocích, a to v následujícím sledu:

\section{Současný stav trhu práce}

V této kapitole jsou představeny informace týkající se stavu a struktury zaměstnanosti, vzdělanostní a kvalifikační úrovně pracovní síly, nezaměstnanosti a politiky zaměstnanosti v České republice. Dále je nastíněno srovnání současného stavu trhu práce na úrovni Evropské unie, Plzeňského a Jihočeského kraje.

\section{Dopady technologických změn na poptávku po pracovní síle}

Kapitola diskutuje segment ohrožených pracovních pozic, skupin obyvatelů a sektorů. Uvádí též do problematiky tvorby nových pracovních pozic a měnícího se charakteru pracovních míst.

\section{Požadované znalosti, dovednosti a kvalifikace v souvislosti s nástupem a rozvojem Společnosti 4.0}

Společnost 4.0 razantním způsobem mění požadavky na znalosti, dovednosti a kvalifikaci zaměstnanců. Jaké požadavky vznikají a jak naložit se zaměstnanci, jejichž pracovní místa byla nahrazena, uvádí kapitola 3.

\section{Nutnost dalšího vzdělávání a rekvalifikací v souvislosti s nástupem a rozvojem Společnosti 4.0}

Silnou roli v oblasti Společnosti 4.0 hraje digitální gramotnost, především té se věnuje čtvrtá kapitola, která se zaměřuje na tematiku dalšího vzdělávání a rekvalifikací. Nejprve je diskutována problematika digitální gramotnosti obecně, následně je vztažena k národní strategii pro digitální gramotnost a je posouzen současný stav $v$ této oblasti.

5. Identifikace ohrožených pozic v sektoru znalostně náročných služeb v souvislosti s nástupem a rozvojem Společnosti 4.0

Závěrečná kapitola, v návaznosti na předchozí kapitoly, otevírá prostor pro identifikaci ohrožených pozic v sektoru znalostně náročných služeb v souvislosti s rozvojem Společnosti 4.0. Byla nastavena vlastní kritéria pro výběr vzorku podniků, které se identifikují se sektorem znalostně náročných služeb a následně byly tyto sektory navrženy.

Shrnutí stěžejních změn, které byly prostřednictvím studie 2 identifikovány, nastiňuje následující text:

- Dojde $\mathrm{k}$ propouštění nízkokvalifikovaných dělníků ve výrobě. Zde se předpokládá nahrazení těchto pracovních pozic autonomními stroji. Lidský faktor se bude nahrazovat roboty, počítači apod.

- Nejvíce ohrožené pozice budou rutinní činnosti, které spočívají v pravidelných a opakujících se aktivitách a pracovních postupech. Do velké míry dojde i k odstranění fyzicky náročné práce.

- Pro Českou republiku se odhaduje, že během 20 let dojde $z$ důvodu informatizace, kybernetizace a digitalizace $\mathrm{k}$ silnému ohrožení $10 \%$ pracovních míst a u $35 \%$ pracovních míst dojde $\mathrm{k}$ podstatným změnám ve vykonávaných činnostech.

- Vznik nových pracovních př́ležitostí, které si v současné době lze i těžko představit.

- Vznik nových oborů a současně zánik konkrétních profesí a oborů.

- Předpokládá se rozšiření zaměstnanosti ve službách. Dále se očekává vysoký nárůst zaměstnanců v oboru informační technologie. A dále nárůst poptávky po pracovní síle více technicky vzdělané a schopné pracovat s novými technologiemi a umělou inteligencí (například profese systémových architektů, designerů, testovacích pracovníků). Stejně tak se budou více rozvíjet specializované profese pro sběr, uchování, přesnost dat, propojení strojního inženýrství se znalostní elektronikou, kybernetikou a informatikou.

- Ceněny budou zejména pracovní síly s mezioborovými vlastnostmi, se strategickým či inovativním myšlením, nadprůměrným vzděláním, technickým vzděláním a měkkými dovednostmi. Zároveň 
se zvýší požadavky na kombinaci dovedností jako - spolupráce, kreativita, kritické myšlení, schopnost řešit problémy, analytické myšlení.

- Očekává se větší flexibilita práce. S tím souvisí i vznik nových forem zaměstnávání (například sdílení zaměstnanců, sdílení pracovního místa, dočasné řízení, příležitostná práce, mobilní práce založená na informačních a komunikačních technologiích atd.).

- Organizace se budou přizpůsobovat novou strukturou a využitím nových sdělovacích prostředků.

- S novými technologiemi by měl být umožněn širší vstup subjektů (i malých), které se budou moci podnikatelsky realizovat, i bez ohledu na lokální aspekt.

- Změny vytvářejí tlak na změnu vzdělávacího systému dle budoucích potřeb pracovního trhu.

- Vzdělání se nebude již jako doposud přizpůsobovat jednomu povolání, nýbrž důraz bude kladen na komplexnost, mezioborovost, kreativitu a flexibilitu.

- Je proto nutná reforma celého školství včetně nastavení nového přístupu společnosti ke konceptu digitálního vzdělávání. Ten by měl zahrnovat nové moderní osnovy výuky s důrazem na matematiku a ICT, nové interdisciplinární studijní programy zaměřené na Průmysl 4.0 na pomezí oborů strojírenských, elektrotechnických a informatických, rozvoj digitální gramotnosti napříč populací s ohledem na oblast služeb (důraz na ohrožené osoby na trhu práce) a digitalizaci ve veřejné správě.

\section{B.2 DOTAZNÍKOVÉ ŠETŘENÍ}

\section{B.2.1 Výběr vzorku podniků pro dotazníkové šetření}

Vzhledem k sídlu projektových týmů se výzkum soustředil na dva regiony - Plzeňský a Jihočeský kraj. Potenciální respondenti byli identifikováni filtrováním z databáze Albertina - Bisnode podle následujících kritérií:

- Sídlo firmy - Plzeňský a Jihočeský kraj.

- Velikost firmy - malé a střední podniky podle definice EU.

- Odvětví - převažující NACE sekce J - informační a komunikační aktivity a M - profesionální, vědecké a technické aktivity.

Výsledkem hledání byla souhrnná zpráva a excelovská tabulka obsahující základní informace o firmách včetně kontaktů (e-mail, telefonní čísla) a www stránek. Tato data byla použita ke kontaktování potenciálních respondentů.

Bylo identifikováno 622 firem v Plzeňském kraji a 853 v Jihočeském kraji, z nich bylo 296 firem v odvětví NACE sekce J a 1179 firem v sekci M. Většina firem v tomto vzorku jsou mikro- a malé podniky.

\section{B.2.2 Dotazníkové šetření}

Dotazník, připravený v aplikaci Google Forms, byl rozeslán vybraným firmám. Dotazníkové šetření probíhalo od 5. 6. do 15. 11. 2019.

Dotazník je dostupný na adrese https://forms.gle/FWoeQSuhrw2X8Mh6A.

Návratnost nebyla velká (cca $10 \%$ ) - do poloviny listopadu bylo získáno 141 odpovědí. Nízká návratnost mohla být způsobena přetížeností firem mnoha dotazníkovými šetřeními, ke zvýšení návratnosti přispěly osobní kontakty členů projektového týmu s firmami. 
Výsledky této fáze projektu byly zpracovány ve formě příspěvku „Knowledge Intensive Services in Pilsen and South Bohemia regions", odeslaného k publikaci v odborném časopisu, a v prezentaci na workshopu č. 1 „Adaptace sektoru znalostně náročných služeb na podmínky Společnosti 4.0" (Vacek, 2020).

\section{B.2.3 Závěry dotazníkového šetření}

- Více než $60 \%$ respondentů pracuje $v$ organizaci déle než 5 let, přibližně $2 / 3$ z nich pracují v manažerských pozicích.

- Největší podíl respondentů působí v opravárenství a službách (NACE 95), následují ostatní profesionální, vědecké a technické aktivity, reklama a marketing, právní a účetní služby a IT.

- Většina respondentů získává znalosti z vnějších zdrojů, tj. jsou více uživateli než tvůrci znalostí. Pracují v modelu otevřených inovací, ochrana duševního vlastnictví je většinou (asi ve $3 / 4$ firem) neformální (obchodní tajemství) nebo automatická (copyright). Formální ochrana průmyslového vlastnictví (patenty, užitné vzory atd.) není často používána.

- Většina firem využívá svých současných znalostí nyní nebo očekává jejich využití během 1-5 let.

- Nejvyšší přidaná hodnota ve firmách je vytvářena v zákaznických službách, nejmenší v řízení rizik. Př́stup k rizikům by se měl zlepšit, riziko může negativně ovlivnit fungování firmy.

- Užití existujících kompetencí výrazně převyšuje nad hledáním nových způsobů podnikání. Takový přístup může negativně ovlivnit konkurenceschopnost firmy.

- Prosazování tvorby nových znalostí a hledání nových způsobů podnikání může být podpořeno rozvojem kompetencí. Většina firem používá a podporuje učení se prací, následuje celoživotní vzdělávání. Trochu překvapivé je to, že nikdo nepoužíá rotace pracovních pozic (to může vyplývat z velikosti firmy - v malých firmách často není kde rotovat). Více než polovina respondentů dává přednost průběžnému zdokonalování.

- $\quad V$ rychle se měnícím prostředí firmy jsou - a budou - stále více vystaveny změnám. $V$ našem vzorku manažeři vyjadřují v 75 \% podporu změn, méně optimističtí jsou respondenti na nižších pozicích (jen 50 \% odpovídá, že jejich management podporuje změny). Převažující počet firem (cca 75 \%) odpovědělo, že dostatečně podporuje zavádění nových nástrojů a technologií.

Pokud jde o manažerské kompetence, jako nejdůležitější byly vyhodnoceny ty, které se vztahují k měkkým dovednostem (soft skills); Ize předpokládat, že $v$ budoucnosti převládne leadership (dělat věci správné) nad tradičním managementem (dělat věci správně). Překvapující je nízké hodnocení významu rozhodování za nejistoty - to může být v řadě případů slabou stránkou firmy.

\section{B.3 ŘíZENÉ ROZHOVORY}

Hlavním cílem řízených rozhovorů v rámci projektu Adaptace sektoru znalostně náročných služeb na podmínky Společnosti 4.0 bylo získat dodatečné informace o využívání znalostí $v$ daném podniku a analyzovat adaptaci společností na rozvoj nových technologií tzv. Průmyslu 4.0, resp. Společnosti 4.0. Dále jsme chtěli rozšíritit, potvrdit a dopInit poznatky získané v rámci dotazníkového šetření.

Bylo osloveno několik desítek podniků z Plzeňského a Jihočeského kraje. Řada z nich ale bohužel odmítla na výzkumu participovat, a to z důvodů vysoké pracovní zátěže.

Řízené rozhovory probíhaly $v$ druhé polovině roku 2019 a prováděli je zaškolení zaměstnanci obou účastníků projektu, tj. Západočeské univerzity v Plzni a Vysoké školy technické a ekonomické v Českých Budějovicích. Celkem bylo respondentům položeno 11 hlavních a 24 doplňujících otázek, 
které sloužily $\mathrm{k}$ detailnějšímu zjištění názoru respondentů. Doplňující otázky byly součástí hlavních otázek 1 až 9. Osloveni byli manažeři/vlastníci firem.

Rozhovory byly záměrně koncipovány ve strukturované podobě, kdy byla respondentovi položena otázka s určitým zaměřením a na ni poté respondent reagoval. $V$ prípadě, že respondent odpověděl konkrétně, byla mu navíc položena i otázka doplňující. Důvod pro volbu strukturovaných rozhovorů byl ten, že díky této metodě můžeme zjistit přesnější a komplexnější odpověd' respondenta na konkrétní otázku a máme následně možnost odpovědi více respondentů porovnat a vyhodnotit.

Otázky 1-9 se týkaly následujících témat:

- Připravenosti firmy na technologické změny a prognózy ve vztahu Společnosti a Průmyslu 4.0, a to po stránce připravenosti koncepční a podnikové strategie.

- Způsobu a rychlosti adaptace firmy na změny v souvislosti se Společností a Průmyslem 4.0.

- Kritických faktorů firmy v souvislosti její úspěšnou adaptací na podmínky Společnosti a Průmyslu 4.0.

- Vhodnosti a možností využití veřejné podpory a dotací pro adaptaci firmy na podmínky Společnosti a Průmyslu 4.0.

- Vnímání konkurenčního boje v odvětví jako motivačního faktoru k rychlejší adaptaci a k inovacím v souvislosti se Společností a Průmyslem 4.0.

- Spolupráce firmy se zákazníky/klienty/dodavateli jakožto motivačními činiteli $k$ adaptaci a inovacím v souvislosti se Společností a Průmyslem 4.0.

- Zkušeností firmy s outsourcingem znalostně náročných služeb.

- Názoru na počet a dostatek vyškolených zaměstnanců ve firmě v souvislosti se Společností a Průmyslem 4.0.

- Možností automatizovat či poloautomatizovat některé procesy ve firmě.

Otázka 10 byla otázkou otevřenou a jejím cílem bylo zmapovat vlastní postřehy firmy k problematice Adaptace sektoru znalostně náročných služeb na podmínky Společnosti 4.0.

Otázka 11 se týkala námětů firmy k řešené problematice ve vztahu k projektovému týmu a možností i ochoty participovat na řešení projektu.

Získaný vzorek firem činil 16 MSP. Je potřeba mít stále na mysli, že malé a střední podniky jsou středem zájmu tohoto projektu. Pro připomenutí uvádíme, že základním kritériem pro posouzení velikosti podniku je počet zaměstnanců, velikost ročního obratu a bilanční suma roční rozvahy (velikost aktiv). S rozhovorem souhlasili také zástupci čtyř velkých firem. Pro srovnání stavu připravenosti uvádíme jejich odpovědi v závěru této kapitoly.

\section{B.3.1 Vyhodnocení rízených rozhovorů}

Realizované řízené rozhovory přinesly především následující zajímavé poznatky:

a) Co se týká připravenosti firem na technologické změny a prognózy ve vztahu Společnosti a Průmyslu 4.0, uvedlo $62 \%$ oslovených, že jsou na tyto změny připraveny. Problémem ovšem je, že až $68 \%$ z nich nemá připraven relevantní strategický ani koncepční dokument. Nicméně zavádění změn v oblasti digitalizace a automatizace považují za důležité.

b) Více než polovina z oslovených firem (56 \%) zavádí požadované technologie kontinuálně, poprípadě dle potřeby. 
c) Přes 60 \% oslovených firem uvádí, že v rychlejší adaptaci na podmínky Společnosti 4.0 jim brání především nedostatečně kvalifikovaný personál a finanční prostředky k pořízení potřebného vybavení. Z hlediska dalších faktorů omezujících rychlost adaptace firmy uvádí nedostatek časových možností. V současných procesech firmy využívají nejvíce softwarové vybavení (vzdálený přistup, cloudová úložiště) a upgrade tohoto vybavení. 50 \% podniků si neuvědomuje žádné kritické faktory, které by jim bránily v úspěšné adaptaci v kontextu Společnosti 4.0. Určitý problém však spatřují $v$ konzervativnosti plnění pracovních úkolů a vnitřním pocitu nepotřebnosti adaptace na nové společenské koncepty. Necelých $40 \%$ respondentů sdílí myšlenku, že vedoucí pracovníci nemají potřebné znalosti k realizaci postupů a nástrojů Společnosti 4.0. Zbývající část respondentů považuje kvalifikaci vedoucích pracovníků $v$ této oblasti za dostatečnou.

d) Motivaci pro implementaci požadavků Společnosti a Průmyslu 4.0 spatřují vedoucí pracovníci $\checkmark$ možnostech konzultací $v$ rámci různých odborných seminářŭ, školeních či konferencích. Oslovené firmy také zdůrazňují, že důvodem pro prosazování změn není pouze finanční odměna, ale také zvýšení rychlosti fungování podniku a z toho vyplývající časová úspora.

e) Ohledně využití veřejné podpory nepanuje mezi oslovenými firmami jednota v názorech. $43 \%$ firem uvádí, že je vhodné a důležité využívat podpory ve formě dotací, stejný počet oslovených tuto možnost odmítá. I přesto, že respondenti sledují nabídky získání finančních prostředků prostřednictvím veřejné podpory, tuto možnost zpravidla nevyužívají. Důvodem, který uvádí, je administrativní složitost při prípravě podkladů, nedostatečné personální kapacity, problematický výklad zadávací dokumentace a také stanovení minimálních částek pro pořízení nového IT vybavení.

f) Konkurenční boj je vnímán 30 \% dotazovaných jako silný, avšak je zároveň chápán jako přirozená součást fungování tržní ekonomiky a zdroj informací, které mohou být využity při adaptaci podnikového prostředí na Společnost a Průmysl 4.0. V rámci vnímání konkurenčního boje, jakožto motivačního nástroje, potvrzuje 56 \% respondentů, že ho vidí jako nástroj zdravé soutěže, který podněcuje k neustálému zlepšování a docílení vyšší kvality nabízeného produktu a služeb.

g) Všechny oslovené firmy se vyjádřily ke spolupráci v rámci svých obchodních vztahů velmi pozitivně. Spolupráce funguje partnerským způsobem a je vnímána jako př́nosná a velmi významná, a to nejen ve vztahu s obchodními partnery, ale i koncovými zákazníky. Je tomu tak zejména v oblasti přizpůsobení produktů a služeb konkrétním skupinám zákazníků. Dochází tak průběžně $k$ tvorbě dodavatelsko-odběratelských řetězců, $v$ rámci kterých je nezbytné vytvářet a udržovat pozitivní vazby s obchodními partnery. Toto považuje za důležité $81 \%$ dotázaných firem. Spolupráce je vyhledávána také z důvodu výzkumu a implementace nových technologií do podnikového prostředí. Spolupráce firem se zákazníky/klienty/dodavateli je tedy výrazným motivačním činitelem $\mathrm{k}$ adaptaci a inovacím v souvislosti se Společností a Průmyslem 4.0.

h) Použití outsourcingu potvrzuje celá polovina dotázaných firem. Jako hlavní důvod uvádí náročnost pro vlastní zaměstnance, získání pomoci v oblasti, kterou firmy samy neznají, finanční náročnost a časové důvody $\mathrm{k}$ dosažení požadovaného výsledku. Outsourcují se především IT služby, účetnictví, právo, popř. externí audity. Pozitivně hodnotí outsourcing $81 \%$ oslovených firem a necelých 70 \% ho plánuje využivat i nadále, a to zejména ve specifických oblastech, jež hrají v podniku roli podpůrných procesů.

i) Naléhavou potřebu disponovat vyškolenými pracovníky v rámci konceptu Společnosti 4.0 si uvědomuje 50 \% dotázaných firem a nedostatek těchto pracovníků vnímají jako kritický. Jako další limitující faktor firmy uvádí všeobecně ochotu pracovat. 83 \% respondentů se snaží získat nové a kvalitní pracovníky tím, že nabízí vyšší mzdy, dále možnosti osobního růstu a různé nefinanční benefity. $V$ prípadě prijijetí absolventů škol bývají firmy často zklamány jejich 
nedostatečnou odbornou úrovní. Potřebu investovat do dalšího vzdělání svých zaměstnanců cítí jako důležitou $75 \%$ dotázaných firem, a sice prostřednictvím seminářů, manažerských kurzů atp.

j) Automatizace procesů závisí na zaměření jednotlivých podniků. V rámci zkoumaného vzorku $75 \%$ dotázaných uvádí, že žádné takové vhodné procesy nemají, nicméně $56 \%$ z dotázaných o automatizaci přemýšlí. Na druhé straně podniky uvádějí, že rutinní procesy již vesměs zautomatizované mají. Jedná se především o účetní procesy. Více než polovina firem se neobává ohrožení pracovních pozic s př́ípadnou vyšší automatizací. Část dotázaných se v souvislosti se zahájením fáze automatizace vybraných procesů obává o ztrátu zaměstnání, a to hlavně $z$ důvodu nadbytečnosti. $V$ př́padě, že by $k$ tomu mělo dojít, jsou firmy připraveny procesy automatizovat postupně $a \mathrm{v}$ rámci sociálně odpovědného podnikání ve vztahu k zaměstnancům.

k) Mezi podniky existuje shoda v tom, že implementace konceptu Společnosti 4.0 do procesů firem je nutná. Doporučují např. uživání cloudových řešení. Nicméně si uvědomují, že budou stále existovat profese, které budou i nadále nuceny využívat lidskou sílu a individuální príistup.

I) Podniky vnímají podporu ze strany výzkumného týmu jako pozitivní a vítají ji. Primárně byl projeven zájem o sdílení zkušeností formou workshopů či seminářu. Očekává se i poradenská činnost ze strany projektového týmu, školení a zpř́stupnění všech zpracovaných výstupů projektu „Adaptace sektoru znalostně náročných služeb na podmínky Společnosti 4.0" na veřejně přistupných webových stránkách projektu (https://azis.zcu.cz).

Pro srovnání byla realizována i malá výzkumná sonda ve čtyřech velkých firmách orientujících se na poskytování znalostně náročných služeb. U těchto firem je markantní, že jsou, ve srovnání s MSP, lépe připraveny na technologické změny v rámci adaptace na Společnost a Průmysl 4.0. a adaptace je součástí jejich podnikové strategie. Využívání moderních technologií je zásadní pro dosažení jimi stanovených cílů. Pro tyto firmy je důležitá rovněž rychlost při zavádění jednotlivých inovací, a to nejen z pohledu konkurenčního prostředí. I u velkých firem je rychlost adaptace na Společnost a Průmysl 4.0 závislá na finančních možnostech a přístupu firmy jako takové. Většinou firmy přestupují na nové technologie až ve chvíli, kdy se to vyplatí, a činí tak postupně. Firmy popisují jako kritické pro zavádění nových technologií několik faktorů, mezi které patří především konkurence, rychlost zavádění změn a kvalita zaměstnanců. Kvalitní zaměstnance si velké firmy proto snaží udržet prostřednictvím celé škály benefitů. K aplikaci nových technologií využívají velké firmy častěji možnosti veřejné podpory, ale i ony shledávají administrativní zátěž jako limitující. Stejně jako MSP vnímají také velké firmy jako důležitý faktor úspěchu kvalitní spolupráci se zákazníky či dodavateli. Velké firmy často využívají, stejně jako MSP, outsourcing, a to především v oblasti IT, externích auditů a projektové činnosti.

\section{B.4 KRITICKÉ ASPEKTY}

Kritické aspekty Ize definovat jako události, které mohou projekt či zavádění koncepce ovlivnit. Kritické aspekty hodnotíme podle pravděpodobnosti nastání a jejich dopadu, pokud dané události nastanou. Dopad neočekávané události může být negativní, poté hovoříme o riziku, ale i pozitivní, pak mluvíme o príležitosti.

\section{B.4.1 Rizika projektu a koncepce Společnost 4.0}

Termín riziko budeme dále používat pro události s negativním dopadem. Prvním krokem řízení rizik je jejich identifikace, tj. vytvoření seznamu potenciálních rizik. Po identifikaci rizik je třeba odhadnout jejich pravděpodobnost a dopad. Na základě pravděpodobnosti a dopadu rizik je pak stanovena jejich závažnost a navržen způsob jejich ošetření, a to jednak preventivní - možnost 
snižení pravděpodobnosti a/nebo dopadu ve stádiu plánování, a jednak následné - jakou akci provést, pokud k riziku došlo a chceme minimalizovat jeho dopad.

Rizika, která byla identifikována $v$ návrhu projektu Adaptace sektoru znalostně náročných služeb na podmínky Společnosti 4.0, jsou shrnuta v Tab. 1.

Tab. 1: Rizika projektu

\begin{tabular}{|c|c|c|c|c|}
\hline ID & Identifikované riziko & Pravděpodobnost & Dopad & Závažnost \\
\hline R1 & $\begin{array}{l}\text { Personální } \\
\text { (fluktuace důležitých pracovníků) }\end{array}$ & Nízká & Malý & 4 \\
\hline R2 & $\begin{array}{l}\text { Organizační } \\
\text { (řízení a management řešitelů a dalších účastníků) }\end{array}$ & Velmi nízká & Velmi malý & 1 \\
\hline R3 & $\begin{array}{l}\text { Finanční } \\
\text { (ztráta platební schopnosti dalších účastníků) }\end{array}$ & Velmi nízká & Velmi malý & 1 \\
\hline R4 & Ztráta schopnosti uplatnění výsledku & Nízká & Malý & 4 \\
\hline R5 & $\begin{array}{l}\text { Změna projektu } \\
\text { (na základě zkoumání v průběhu řešení) }\end{array}$ & Velmi nízká & Velmi malý & 1 \\
\hline R6 & $\begin{array}{l}\text { Stav a vývoj hospodářského cyklu a s tím související } \\
\text { možnost malých a středních podniků v sektoru } \\
\text { služeb investovat do technologických komponent } \\
\text { Průmyslu } 4.0 \text { - Společnosti } 4.0 \text {. }\end{array}$ & Střední & Větší & 12 \\
\hline R7 & $\begin{array}{l}\text { Finanční možnost malých a středních podniků } \\
\text { v sektoru služeb investovat do zvyšování úrovně } \\
\text { znalostního potenciálu pracovního kapitálu } \\
\text { a zvyšování kvalifikace pracovní síly. }\end{array}$ & Střední & Větší & 12 \\
\hline
\end{tabular}

Zdroj: vlastní zpracování dle Zadávací dokumentace projektu TAČR TL02000136, 2020

Pravděpodobnosti a dopady rizik uvedené v Tab. 1 vychází z expertního odhadu.

\section{Analýza rizik}

R1: Riziko personální bylo identifikováno jako riziko s nízkou pravděpodobností a malým dopadem, nebot členové řešitelského týmu jsou převážně zaměstnanci hlavního a dalšího řešitele s pracovními smlouvami na dobu neurčitou s plným pracovním úvazkem.

R2: Riziko řízení a managementu př́ijemce a dalšího účastníka projektu bylo identifikováno jako riziko $s$ velmi nízkou pravděpodobností a velmi malým dopadem, nebot' členové řešitelského týmu mají zkušenosti s organizací, koordinací a řízením projektů.

R3: Finanční riziko bylo identifikováno jako riziko s velmi nízkou pravděpodobností a velmi malým dopadem vzhledem $\mathrm{k}$ dlouhodobé finanční situaci účastníků projektu.

R4: Riziko ztráty schopnosti uplatnění výsledku bylo identifikováno jako riziko s nízkou pravděpodobností a malým dopadem (uplatnění výsledků projektu $v$ praxi je podpořeno a potvrzeno externími aplikačními garanty a analýzou potřeb podnikové praxe).

R5: Riziko změny projektu bylo identifikováno jako riziko $s$ velmi nízkou pravděpodobností a velmi malým dopadem (předchozí rešerše problematiky Průmysl 4.0 - Společnost 4.0, předchozí analýza potřeb podnikové praxe, předchozí spolupráce, diskuse a konzultace $s$ externími aplikačními garanty). 
R6: Riziko vývoje hospodářského cyklu, a s tím související možnost malých a středních podniků investovat do technologických komponent Průmyslu 4.0 - Společnosti 4.0, bylo identifikováno jako riziko se střední pravděpodobností a větším dopadem.

R7: Riziko nedostatečné finanční možnosti MSP v sektoru služeb investovat do zvyšování úrovně znalostního potenciálu pracovního kapitálu a zvyšování kvalifikace pracovní síly bylo vyhodnoceno stejně jako riziko R6 se střední pravděpodobností a větším dopadem.

Rizika R1, R2, R3 a R5 jsou interní rizika spojená s řízením projektu, jsou pod kontrolou řešitelského týmu. Z pohledu rizik dosažení, uplatnitelnosti a udržitelnosti výstupů projektu jsou důležitá rizika R4, R6 a R7.

Riziko R4 bude ovlivněno kvalitou výsledného produktu projektu, to je předkládané metodiky. Jeho pravděpodobnost i dopad lze zmírnit důsledným zaměřením návrhu postupů adaptace na koncového uživatele, to je management a personál MSP: je třeba brát $v$ úvahu časové vytížení a personální kapacity cílové skupiny, postupy musí být formulovány stručně $s$ tím, že v případě zájmu mohou být aktualizovány a doplňovány jak v průběhu testování metodiky, tak po skončení projektu, čímž by bylo možné podpořit udržitelnost jeho výsledků. Důležitou roli bude hrát testovací fáze projektu a zahrnutí zpětných vazeb získaných od externích aplikačních garantů projektu i koncových uživatelů - MSP.

Nejzávažnější rizika R6 a R7 nemůže projektový tým ani cílová skupina (MSP) výrazně ovlivnit a vzhledem $k$ nastalé situaci (pandemie COVID-19) je zřejmé, že jejich závažnost přinejmenším $v$ době trvání projektu výrazně vzroste. Na druhou stranu se stane tím důležitějším adaptace MSP v sektoru služeb vyvolaná nejen konceptem Společnost 4.0, ale výrazně ovlivněná zotavováním ekonomiky $z$ důsledků způsobených karanténními opatřeními (těmito aspekty se podrobněji zabýváme $v$ subkap. B.4.3). Lze předpokládat, že mnohé organizace budou vystaveny velkým tlakům na změny a ty z nich, které dokážou využít príležitostí nabízených současnou situací (práce z domova, digitalizace, změna produktu a služeb vedoucí třeba i ke změně oboru podnikání), mohou získat konkurenční výhodu. Podniky, které se nedokáží flexibilně adaptovat, se dostanou do krize a mnohé z nich mohou zaniknout. Lze předpokládat, že podniky z cílové skupiny projektu - znalostně intenzivní služby - jsou ve srovnání s jinými obory ve výhodě, práce se znalostmi je pro ně podstatou jejich činnosti a mnohé z nich prokazují i v obtížné situaci značnou dávku flexibility a adaptability.

Jednou z bariér inovací v podnicích cílové skupiny projektu může být nedostatek zdrojů, a to jak lidských zdrojů vybavených potřebnými kompetencemi a ochotných učit se, tak finančních. Pokud jde o finanční zdroje, mnohé podniky, zvláště malé a střední, se díky omezením spojeným s pandemií koronaviru dostalo do velice obtižné situace a významnou roli ve "znovunastartování ekonomiky bude hrát stát $\mathrm{s}$ jasně stanoveným rozsahem a načasováním podpory MSP.

\section{B.4.2 Příležitosti zavádění a využívání principů Společnosti 4.0}

Kromě rizik významnou roli při zavádění a využívání principů Společnosti 4.0 hrají příležitosti a na podnicích je, aby uvedené př́ležitosti byly z jejich strany využity v maximální možné miře.

Nový trend, spojovaný s pojmy Společnost 4.0, Průmysl 4.0, Digitální společnost či Digitální ekonomika, představuje pro podniky dokonce velkou řadu př́ležitostí. Revoluční změny v uspořádání prakticky všech produktů i jejich výrobních postupů otevřou dveře rozsáhlé inovaci a generační výměně v podstatě ve všech oborech (Business.info, 2016).

V souvislosti s uvedenými pojmy a principy digitalizace je zřejmé, že zásadní výhody budou mít velké nadnárodní korporace jakožto lídři trhu, kteří mají v rukou nejvyspělejší technologie a dostatečné zdroje pro financování inovací, což se jim nedá upř́it, avšak i na úrovni malých a středních podniků, které mají významné postavení zejména na českém trhu, Ize nalézt výhody, které mohou tyto 
podniky proměnit na příležitosti. Jmenovat Ize například schopnost menších podniků na českém trhu umět improvizovat a flexibilně reagovat na změny ve společnosti, a to nejen $v$ oblasti vyspělých technologií. České malé a střední podniky jsou zároveň ceněny ve světě za to, že umějí budovat digitální architekturu a mají snahu činit strategická rozhodnutí (Business.info, 2016).

Principy Společnosti 4.0, digitalizace a automatizace zasahují také pracovní trh. Většinou uvedenou skutečnost mnozí vidí jako hrozbu, ale lze na ni pohlížet jako na zajímavou př́ležitost, kdy se očekává vznik nových profesí, a to zejména $v$ oblasti služeb. $V$ tomto aspektu je třeba dále sledovat potřebu celoživotního vzdělávání, vzdělávání dospělých, které se v kontextu Průmyslu 4.0 často označuje jako digitální vzdělávání. Digitální vzdělávání Ize definovat jako vzdělávání, které reaguje na změny ve společnosti související s rozvojem digitálních technologií a jejich využíváním v nejrůznějších oblastech lidských činností (Centrum andragogiky, 2017). Zde však nelze zjednodušit pouze na kvalitní znalosti a dovednosti v IT technologiích. Důležitá je též kreativita, umění komunikace, práce s informacemi, kritické myšlení, znalosti cizích jazyků apod. To všechno je velkou přiležitostí pro firmy, které toto musejí pojmout jako potenciální konkurenční výhodu a musí mít digitálně vzdělané zaměstnance. Zároveň je daná skutečnost velkou přiležitostí pro mnoho vzdělávacích institucí, at soukromých či veřejných.

V době pandemie COVID-19 se ukázalo, že mnohé firmy i školy pružně rychle přešly na práci z domova a využití digitálních technologií ve vzdělávání. To, o čem se léta diskutovalo, vytvářely se strategie apod., si našlo cestu během několika týdnů. Lze doufat, že nově získané kompetence budou využívány i nadále.

Shrneme-li dopady Společnosti 4.0 na vybrané subjekty, zejména v otázkách možných př́ležitostí, Ize souhlasit s dokumentem Deloitte (2017a) - viz text dále:

Dopady na podniky - organizační úroveň:

- $\quad$ podnikové operace

- zlepšení produktivity: maximalizace využití aktiv a minimalizace prostojů, přímé a účinné řízení práce, řízení nákladů na zásobovací sít a synchronizace zásobování, zajištění harmonogramu přesnějšího a stabilního plánování,

- snižování rizika: zajištění cen a dostupnosti surovin, ř́zení záruk a efektivnější připomínkovací řízení, zmírňování rizik daných geografickými rozdíly.

- růst podniku

- př́růstek stávajících přímů: nalezení zdrojů růstu pro hlavní podnikatelskou činnost, růst toků tržeb s následným trhem, prohloubení pochopení a porozumění zákazníkům, posílení zákaznické integrace a distribučních kanálů,

- nové př́ijmy: tvorba nových produktů a nabídka nových služeb, rozšiřování se na mezinárodní úroveň a rozvoj trhů, identifikace atraktivních přiležitostí spolupráce a zapojení do sítí.

Podnikové oblasti ovlivněné konceptem Průmysl 4.0 zahrnují tvorbu a rozvoj nových produktů, nové business modely, rozvoj procesů, dodavatelské řetězce a vztahy se zákazníky.

Dopady na zaměstnance:

- zjednodušení práce díky používání moderních technologií, které nahradí rutinní formy práce,

- růst výstupů,

- možnost vzniku či změn v zaměstnaneckých rolích (práce z domova, flexibilní úvazky), nových výrobcích a postupech. 
Významné benefity pro zákazníky:

- užší interakce mezi firmou a zákazníkem,

- vytváření a využití vhodných dat pro analýzu na základě zákazníkových potřeb a jeho chování, zapojení umělé inteligence,

- integrace dat s historickými informacemi a daty od zákazníků mohou podpořit lepší pochopení procesů, výrobků či služeb ze strany zákazníků a také predikovat zákazníkovy preference, zapracovat zpětnou vazbu do vývoje, výzkumu a procesů podniku.

Další významné př́ležitosti pro podniky:

- zaměření se na inovace,

- budování ekosystémů,

- tvorba nových strategií,

- pokračování ve změnách.

PortálDigi (2017) se též přidává k výše uvedenému a uvádí, že podniky mohou vyvinout další služby založené na využívání internetu a získat trhy také za hranicemi klasických branží. Velkou šancí je také změna obchodního modelu z lokálního na globální a zavedení evropského jednotného digitálního trhu.

UNIDO (2018) shrnuje následující přiležitosti konceptu Industry 4.0:

- $\quad$ ekonomický zisk (nižší transakční a přepravní náklady),

- $\quad$ spolehlivější a konzistentní produktivita, výstupy a lepší kvalita výrobků,

- přesun $k$ hromadnému přizpůsobování se jakožto zvýšená šance pro malé a střední podniky,

- zavádění inovací např́č mnoha aplikacemi s velmi rozsáhlými ekonomickými dopady na růst,

- energeticky úsporná a ekologicky udržitelná výroba a systémy (recyklace, cirkulární ekonomika),

- efektivní využívání lidských i materiálových zdrojů,

- zvýšená bezpečnost a ochrana potravin,

- zlepšení v oblasti ochrany zdraví a bezpečnosti zaměstnanců,

- změny ve vzdělávacích a tréninkových systémech,

- více otevřené inovační systémy,

- změny v organizaci práce, napríklad flexibilní práce či práce na vyžádání jako pracovní standardy.

V návaznosti na výše uvedené je třeba zmínit výsledky dotazníkového šetření realizovaného $v$ rámci projektu TAČR („Adaptace sektoru znalostně náročných služeb na podmínky Společnosti 4.0“), které ukázaly, že většina oslovených firem nehledá nové přiležitosti, nehledá nové způsoby podnikání, nepodporuje rotaci pracovních pozic apod. Závažným problémem je též rízení rizik. Na straně druhé $75 \%$ firem podporuje zavádění nových nástrojů a technologií.

Z řízených rozhovorů realizovaných v rámci projektu TAČR vyplynulo, že 68 \% firem nemá relevantní strategický ani koncepční dokument týkající se zavádění změn v oblasti digitalizace a automatizace, ale považují to za důležité. 56 \% firem technologie zavádí dle potřeby. V kontextu uvedeného jako hlavní faktory pro nejasné nastavení procesů pro zavádění změn byly uváděny nedostatečně kvalifikovaný personál, finanční prostředky a časové zatížení.

\section{B.4.3 COVID-19 a př́ležitosti pro digitalizaci a Společnost 4.0}

Ač pandemie COVID-19 přinesla zásadní nepříjemné změny do životů občanů i chodu firem, zároveň je zajímavou př́ležitostí pro oblast digitalizace a konceptu Společnosti 4.0.

Podle aktuálního průzkumu asociace ABSL nahrává současná pandemie podpoře digitalizace, přičemž se ukazuje, že vzdáleně lze realizovat mnohem větší množství aktivit, než bylo dosud běžné. Podnikům se tak otevírají nové možnosti jejich rozvoje - podniky spouští nové služby, rož̌iřují působnost do nových regionů, a to díky masivní podpoře investic a moderních technologií. Z průzkumu $A B S L$ vyplynulo, že pro 
56 \% center podnikových služeb se otvírají nové př́ležitosti. Více než desetina center (12 \%) přebírá procesy od svých sesterských organizací v Asii, kde infrastruktura neumožnila převést všechny lidi na práci z domu, a muselo dojít $\mathrm{k}$ dočasnému útlumu provozu, jiná zase rozšiřují svou regionální působnost anebo poskytují nové služby. Jde zejména o IT podporu zaměstnanců pracujících z domova, konsolidaci dat, digitalizační projekty či zavádění robotické automatizace. Právě s pomocí těchto služeb česká centra umožňují hladké fungování mnohým světovým firmám i nyní, v době pandemie. Pro poskytování podnikových služeb se tedy díky pandemii otevírá mnoho přiležitostí a zároveň krizové scénáře po pandemii by se podnikových služeb neměly týkat, představují totiž jednu z nejširších možností uplatnění znalostní ekonomiky, trendu, který je oproti výrobním oborům nejméně ohrožen ekonomickými krizemi (ITbiz.cz, 2020).

Inovační agentura JIC vidí jako přiležitost možnost přejít u podniků na jednotné online prostředí využívané pro komunikaci na dálku. V oblasti výroby velký nárůst zaznamenal rozvoj využívání 3D tisku a laserových řezaček, častější využívání webinářu a konzultací na dálku, nové business modely, nové produkty. Díky pandemii se do popředí dostává digitalizace vzdělávání, vzdělávací aplikace a vzdálená výuka. Boom zažívají obory jako herní a zábavný průmysl, virtuální realita. Mezi důležité obory se řadí kyberbezpečnost a umělá inteligence, zdravotnické technologie a své důležité místo budou mít i zelené technologie (Obnovitelně.cz, 2020).

Velmi zajímavou př́ležitost dostal $v$ době pandemie i český nanotechnologický průmysl. $\vee$ Evropě je Česká republika prakticky jediná, kdo umí průmyslově vyrábět nanovlákenné membrány a výrobky z nich, jako jsou nanovlákenné respirátory, roušky a filtry do vzduchotechniky. Je to náš unikát a měli bychom si jej náležitě hýčkat. České firmy mají ohromný výrobní, inovační i organizační potenciál k tomu, aby Česko navýšilo své výrobní kapacity udržitelným způsobem. Je zde však nutná podpora vlády a jasné strategické opatření pro strategické segmenty $v$ době pandemie. $Z$ hlediska podpory přiležitostí by tedy bylo účelné, aby alespoň část miliard na nákupy zdravotnických potřeb z Číny byla nasměrována na podporu českých podniků, které by mohly čínské dovozy zčásti nahradit, a to většinou ve vyšší kvalitě (Lipavský, 2020).

Významnou firmou, která bojuje proti nedostatku ochranných pomůcek pro lidi, kteři v první linii bojují s pandemií nového koronaviru, je společnost Prusa Research, vyrábějící na základě dohody s Ministerstvem zdravotnictví ochranné štíty, které může podle jejich návodu kdokoliv vytisknout na 3D tiskárně. Štíty, které vyrábí samotná společnost, jsou nabízeny zdarma nemocnicím, praktickým lékařům, ambulancím, dentistům, lékárnám, policistům, učitelům a dalším profesionálům, ale třeba i do domovů důchodců nebo obchodů s potravinami (Prusa Resarch, 2020).

Samožrejmě firem, které se podílejí na boji proti novému koronaviru, je v České republice mnohem více a patří všem velký dík.

Jak shrnuje Witassek (2020) pandemie zásadně změnila business, což dokazují zejména tyto změny:

- digitalizace ve všech oblastech,

- ovládání hlasem a Internet věcí,

- online technologie i v konzervativních oborech,

- přesun ekonomických aktivit zpět do regionů,

- roboti na rutinní práce $v$ kancelárích,

- umělá inteligence ve strategii firem,

- nové materiály.

Blank (2020) doporučuje v otázkách současných změn zejména udržet firmu naživu, posoudit vnitřní a vnější prostředí, zavádět nové business modely, operační plány a podporovat práci na dálku. Jednat doporučuje rychle, naléhavě a zavést denní komunikaci se zaměstnanci, jedině tak lze nejen situaci ustát, ale zejména vytěžit z nových př́ležitostí. 


\section{KATALOG OPATŘENÍ PRO ADAPTACI MALÝCH A STŘEDNÍCH PODNIKŮ V SEKTORU SLUŽEB NA PODMÍNKY SPOLEČNOSTI 4.0}

Zjištění, popsaná v předchozích kapitolách Metodiky, slouží, společně s dalšími materiály získanými $\checkmark$ průběhu prováděných šetření, konzultací s externími aplikačními garanty a zástupci oslovených podniků a s již publikovanými výstupy projektu (Vacek a kol., 2019; Taušl Procházková a kol., 2019), jako výchozí podklad pro vytvoření Katalogu opatření pro adaptaci malých a středních podniků v sektoru služeb na podmínky Společnosti 4.0.

Cílem tohoto katalogu je navržení konkrétních postupů a kroků, které mají malé a střední podniky v oblasti služeb učinit pro svou úspěšnou adaptaci na nevyhnutelné změny podnikových procesů v souvislosti s nastupující koncepcí Průmyslu 4.0 a Společnosti 4.0.

Katalog rozviji v teoretické i praktické rovině dosavadní výsledky výzkumů v dané oblasti a zaměřuje se specificky na oblast malých a středních podniků v sektoru znalostně intenzivních služeb. Při tvorbě katalogu byly aplikovány podněty a zpětné vazby získané prostřednictvím realizovaného workshopu „Adaptace sektoru znalostně náročných služeb na podmínky Společnosti 4.0" (Taušl Procházková, 2020).

Následující části metodiky, C.1, C.2, C.3, C.4, C.5 a C.6, obsahují doporučená opatření, metody, postupy a nástroje, které mají umožnit efektivní a včasnou změnu chování malých a středních podniků v sektoru služeb a jejich aktivní reakci na změny podnikatelského prostředí související s automatizací, robotizací, elektronizací a digitalizací podnikových procesů. Jedná se o opatření pro oblast inovací, oblast zaměstnanosti a oblast přistupu ke zdrojům včetně opatření zajištujujicích zpětnou vazbu.

\section{C.1 SEBEHODNOCENÍ}

Pro každou organizaci je důležité, aby sledovala svou výkonnost a připravenost na budoucí vývoj. Jedním z nástrojů této aktivity je sebehodnocení, při kterém vedení firmy sleduje vybrané ukazatele, které se pak stávají podkladem pro rozhodování.

Mezi tyto ukazatele patří tzv. klíčové indikátory výkonnosti (Key Performance Indicators - KPI). Dnes asi nejkomplexnějši metodou hodnocení výkonnosti je metoda vyvážených ukazatelů výkonnosti podniku (Balanced Scorecard, BSC), která měří výkonnost podniku pomocí čtyř perspektiv:

- finance a finanční ukazatele,

- interní obchodní procesy,

- zákazníci,

- učení a růst.

Autory metody publikované od roku 1992 jsou Robert S. Kaplan a David P. Norton (Kaplan, Norton, 2001). K této metodě Ize najít mnoho knižních zdrojů i dalších informací na webu (stačí zadat do Googlu klíčová slova Balanced Scorecard). Její zavedení a použití je však značně náročné a používá se převážně ve velkých, často nadnárodních firmách, proto se jí zde bliže nebudeme zabývat.

Modelem, který vychází z konceptu Total Quality Management, je metoda European Foundation for Quality Management (EFQM), viz podrobněji např. na webových stránkách České společnosti pro jakost (ČSJ, 2019). 
Tento model vychází z toho, že pokud chce organizace dosahovat vynikajících výsledků, je třeba splnit následující tři podmínky:

1. dosažení maximální spokojenosti svých pracovníků,

2. dosažení maximální spokojenosti klientů,

3. respektování firmy jejím okolím.

O implementaci této metody platí príibližně totéž jako o metodě BSC.

Pokusili jsme pro vás, malé a střední podniky, navrhnout několik otázek, které by vám pomohly zamyslet se nad odpověd'mi a uvědomit si své silné a slabé stránky spojené s nástupem nových technologií, které jsou popsány v publikaci Identifikace, analýza a hodnocení principů, postupů, metod a nástrojů pro adaptaci sektoru služeb na technické, ekonomické, sociální a environmentální podmínky Společnosti 4.0 (Vacek \& kol., 2019) a shrnuty v následující subkapitole C.2.

Začněme několika otázkami na úvod, $v$ dalších částech této kapitoly pak najdete podrobnější otázky týkající se specifických oblastí působnosti firmy:

- Má vaše firma zavedený systém sebehodnocení?

- Ano - S jakou frekvencí sebehodnocení provádíte? Které KPI sledujete?

- $\quad \mathrm{Ne}$ - Proč ne? Předpokládáte zavedení takového systému? V jakém časovém horizontu?

- Jaký je podle vašeho odhadu ve vaší firmě podíl lidské práce, která může být nahrazena technologiemi Průmyslu 4.0?

- Máte připravené plány profesního růstu vašich pracovníků, které by je připravily na předpokládané změny a vybavily je požadovanými kompetencemi?

- Jaké jsou digitální kompetence vašich pracovníků, jak jsou připraveni na práci v digitalizovaném prostředí?

- Jaký podíl práce může být ve vaší firmě vykonáván z domova formou home office? Jaké je současné využití a jaký podíl práce $z$ domova předpokládáte po krizi?

- Které činnosti ve vaší firmě jsou vhodné pro práci z domova? Které naopak pro tento typ práce vhodné nejsou?

- Jaké prostředky kooperativní práce využiváte (Google, MS Office 365, cloud, videokonference, sdílený kalendář, jiné)?

- Jaké je vaše připojení k internetu (wifi, kabel, mobilní data 4G)? Je vaše infrastruktura dostatečná pro zvládnutí digitalizace? Předpokládáte investice pro její posílení?

- Počítáte s tím, že byste pracovníkům z domova částečně kompenzovali jejich dodatečné náklady za připojení v síti, SW licence apod.?

- Předpokládáte, že digitalizace bude znamenat pro vaši firmu

- Snížení počtu pracovníků (o kolik \%);

- Rekvalifikaci pracovníků na nové pozice;

- Snižení nároků na plochu pracovišt při zvýšeném rozsahu práce z domova;

- Jak by mohly poklesnout náklady vaší firmy spojené s výše uvedenými opatřeními (\% celkových nákladů)? 


\section{C.1.1 Antifragilita, resilience}

\section{Antifragilita}

Nicloas Taleb se ve své knize Antifragilita (Taleb, 2014) zabývá důležitostí odolnosti firmy vůči neočekávaným změnám, tzv. černým labutím (Taleb, 2011) a těžení z chaosu (Peters, 1988), jejichž důležitost se výrazně projevila při restriktivních opatřeních COVID-19, z nichž úspěšně vycházejí především firmy, které se dokázaly pružně přizpůsobit nastalé, zcela neočekávané, situaci. Je nutné, aby se všechny firmy $z$ této situace poučily a byly připraveny na podobná budoucí rizika (sucho, energetika, zdravotnictví, vzdělávací systémy, apod.). Jelikož relevantní pojmy nejsou ještě zcela běžné, začneme jejich stručným popisem a následují otázky, na které byste si měli odpovědět.

$\checkmark$ rámci teorie antifragility je vše na světě možné přiřadit $\mathrm{k}$ jedné $\mathrm{z}$ následujících kategorií:

- fragilní (negativní: věci vyžadující klid; věci s krátkodobou životností),

- odolný (neutrální: věci, které se spokojí s klidem, ale i s chaosem; věci, které v krizi zůstávají stejné),

- $\quad$ antifragilní (pozitivní: věci těžící z chaosu; krizí a tlakem získávají na kvalitě).

Antifragilita je opakem křehkosti a umožňuje věcem, systémům i lidem posilovat na úkor nejrůznějších pohrom a překážek. „Pokud nějaká věc v důsledku nahodilé události (nebo specifického otřesu) spíše získá, než ztratí, je antifragilní; je-li tomu naopak, trpí fragilitou“ (Wikipedia, 2020a).

\section{Resilience}

V blogu PwC Azhar a Droog (2019) uvádějí, že resilience (odolnost) je kompetence, která je stejně důležitá jako technické know-how. Mezi významnými změnami způsobu práce a života lidí jsou kritickými schopnostmi odolnost, vytrvalost a adaptabilita. Úspěšnost $v$ takovém prostředí bude vyžadovat společné úsilí všech stakeholderů - podniků, vlády i jednotlivců - kteří jsou hnací silou změn. Lidé musí aktivně pracovat na svém vlastním úspěchu, ale pokud veškeré brímě zůstane jen na nich, pak ti, kteří nedisponují potřebnými zdroji a kompetencemi, zůstanou pozadu. Samotná resilience, ale ani pouze technický trénink zaměstnanců, nepostačí $k$ tomu, aby byli v turbulentním prostředí úspěšní.

Po seznámení se se základní terminologií můžete nyní přistoupit k sebehodnocení antifragility a resilience vaší firmy - pokuste se vybrat z následující Tab. 2 ty rysy, které jsou charakteristické pro vaši firmu (označte $v$ príslušném sloupci $A$ - ano nebo $N$ - ne a sečtěte výskyty $A$ vobou kategoriích. Tak zjistíte, jaký přístup ve vaší firmě převládá a toto zjištění pro vás může být vodítkem pro další vývoj žádoucím směrem. 
Tab. 2: Charakteristické rysy křehké a antikřehké firmy

\begin{tabular}{|c|c|c|c|}
\hline Křehká firma & $A / N$ & Antikřehká firma & $A / N$ \\
\hline $\begin{array}{l}\text { Firma se snaží vyhýbat krizím, nebo eliminovat } \\
\text { vlivy krizí na její fungování. }\end{array}$ & & $\begin{array}{l}\text { Firma využívá krize jako příležitosti k posílení } \\
\text { a zlepšení své konkurenční schopnosti. }\end{array}$ & \\
\hline $\begin{array}{l}\text { Většina zaměstnanců je izolována od turbulencí } \\
\text { a problémů v okolí firmy a spoléhá se na správné } \\
\text { rozhodnutí majitelů a vrcholových manažerů. }\end{array}$ & & $\begin{array}{l}\text { Spolupracovníci sdílejí a chápou změny v okolí } \\
\text { firmy, uvědomují si, že jsou všichni na jedné } \\
\text { lodi a spolupracují na potřebných změnách ve } \\
\text { firmě tak, aby firma posílila svoji pozici. }\end{array}$ & \\
\hline $\begin{array}{l}\text { Pracovníci pracují podle definovaných cílů } \\
\text { a standardů, problém nastává při radikálních } \\
\text { změnách - převratná technologie na trhu, náhlý } \\
\text { propad trhu, inovace konkurentů, apod. }\end{array}$ & & $\begin{array}{l}\text { Pracovníci se chovají jako společníci, jsou } \\
\text { proaktivní a schopni eliminovat mnohé } \\
\text { problémy v předstihu, rychle a efektivně } \\
\text { reagují na náhlé a nepředvídatelné změny. }\end{array}$ & \\
\hline $\begin{array}{l}\text { Lidé ve firmě jsou št́astní, spokojení, žijí si jako } \\
\text { v bavlnce a odmítají změny. }\end{array}$ & & $\begin{array}{l}\text { Lidé ve firmě jsou zocelení náročnými projekty } \\
\text { a změny berou jako samozřejmost. }\end{array}$ & \\
\hline $\begin{array}{l}\text { Lidé ve firmě jsou zavaleni množstvím úkolů, } \\
\text { projektů a operativních problémů. }\end{array}$ & & $\begin{array}{l}\text { Lidé ve firmě se zabývají zásadně důležitými } \\
\text { věcmi, na které mají reálný vliv. }\end{array}$ & \\
\hline $\begin{array}{l}\text { Lidé jsou trénováni na případových studiích } \\
\text { z minulosti na zvládnutí nejlepších praktik. }\end{array}$ & & $\begin{array}{l}\text { Lidé jsou trénováni na řešení neočekávaných } \\
\text { situací a hledání vlastních řešení a vlastní } \\
\text { cesty. }\end{array}$ & \\
\hline $\begin{array}{l}\text { Ve firmě se sepisují vize, poslání a strategické } \\
\text { plány, v př́ípadě neúspěchu se přepisují. }\end{array}$ & & $\begin{array}{l}\text { Ve firmě se dělají kroky k dosažení } \\
\text { strategických cílů, v případě neúspěchu se } \\
\text { korigují a dělají se další kroky. }\end{array}$ & \\
\hline $\begin{array}{l}\text { Firma se orientuje na předpovídání budoucnosti } \\
\text { (forecasting), přičemž využívá modely } \\
\text { z minulosti. }\end{array}$ & & $\begin{array}{l}\text { Firma se orientuje na objevování budoucnosti } \\
\text { (foresighting), přičemž využívá schopnost vidět } \\
\text { nové trendy. }\end{array}$ & \\
\hline $\begin{array}{l}\text { Hierarchie, řízení shora, vynucená disciplína, } \\
\text { stimulace a homogenita v názorech. }\end{array}$ & & $\begin{array}{l}\text { Decentralizovaná struktura, autonomní týmy, } \\
\text { svoboda a odpovědnost, motivace } \\
\text { a heterogenita v názorech. }\end{array}$ & \\
\hline $\begin{array}{l}\text { Analýza a eliminace rizik, hra na jistotu, robustní } \\
\text { vývoj projektování nových přiležitostí, kritika } \\
\text { chyb a neúspěšných projektů. }\end{array}$ & & $\begin{array}{l}\text { Využívání riskování v malém, experimentování } \\
\text { a akceptace chyb a omylů při hledání nových } \\
\text { příležitostí, agilita. }\end{array}$ & \\
\hline $\begin{array}{l}\text { Firma hledá manažery a pracovníky, kteří jsou } \\
\text { pracovití, disciplinovaní a orientovaní na plnění } \\
\text { strategických cílů. }\end{array}$ & & $\begin{array}{l}\text { Firma hledá kreativní podnikatele, kteří umí } \\
\text { zpochybňovat zaběhaná řešení a baví je řešit } \\
\text { „neřešitelné“ problémy. }\end{array}$ & \\
\hline CELKEM A & & CELKEM A & \\
\hline
\end{tabular}




\section{C.1.2 Adaptace firmy na podmínky Společnosti 4.0}

Následující tabulka by vám měla pomoci posoudit vaše silné a slabé stránky v přípravě na Společnost 4.0. Vyznačte, $v$ jaké míre souhlasíte $s$ následujícími tvrzeními:

Tab. 3: Adaptace firmy na podmínky Společnosti 4.0

\begin{tabular}{|c|c|c|c|c|c|}
\hline Tvrzení & $\begin{array}{l}\text { Silný } \\
\text { souhlas }\end{array}$ & Souhlas & Nesouhlas & $\begin{array}{c}\text { Silný } \\
\text { nesouhlas }\end{array}$ & $\begin{array}{l}\text { Nejsem } \\
\text { si jist(a) }\end{array}$ \\
\hline \multicolumn{6}{|l|}{$\begin{array}{l}\text { Naše organizace v rostoucí míře deleguje } \\
\text { rozhodování na nižší organizační úrovně, aby } \\
\text { dokázala lépe pracovat se znalostmi. }\end{array}$} \\
\hline \multicolumn{6}{|l|}{$\begin{array}{l}\text { Naše organizace potřebuje najít nové lídry, aby } \\
\text { dokázala lépe pracovat se znalostmi. }\end{array}$} \\
\hline \multicolumn{6}{|l|}{$\begin{array}{l}\text { Naše organizace efektivně rozvíjí takové lídry, } \\
\text { kteří mají schopnosti nutné k lepší práci se } \\
\text { znalostmi. }\end{array}$} \\
\hline \multicolumn{6}{|l|}{$\begin{array}{l}\text { Naše organizace aktivně vyhledává nové } \\
\text { prístupy, techniky a nástroje práce se znalostmi, } \\
\text { které by vedly ke zvýšení výkonnosti. }\end{array}$} \\
\hline \multicolumn{6}{|l|}{$\begin{array}{l}\text { Naše organizace má pobočky v několika } \\
\text { geografických oblastech, aby měla lepší prístup } \\
\text { k talentům. }\end{array}$} \\
\hline \multicolumn{6}{|l|}{$\begin{array}{l}\text { Využíváme různé typy pracovních vztahů } \\
\text { (částečný úvazek, konzultant, smluvní vztah, ...) } \\
\text { pro práci se znalostmi. }\end{array}$} \\
\hline \multicolumn{6}{|l|}{$\begin{array}{l}\text { Využíváme pro podporu komunikace pokročilé } \\
\text { kolaborativní nástroje (sdílené úložiště, cloud, } \\
\text { Google dokumenty, ...). }\end{array}$} \\
\hline \multicolumn{6}{|l|}{$\begin{array}{l}\text { Zajímáme se o to, jak mohou nové znalosti } \\
\text { přispět ke zvýšení osobní výkonnosti. }\end{array}$} \\
\hline \multicolumn{6}{|l|}{$\begin{array}{l}\text { Lidé v naší organizaci jsou spokojeni s tím, že je } \\
\text { organizace podporuje v př́pravě na změny } \\
\text { potřebné pro práci se znalostmi (digitalizace, } \\
\text { automatizace, umělá inteligence, ...). }\end{array}$} \\
\hline \multicolumn{6}{|l|}{$\begin{array}{l}\text { Nástroje práce se znalostmi, které získali naši } \\
\text { pracovníci, posilují jejich profesionální profil } \\
\text { v naší organizaci i mimo ni. }\end{array}$} \\
\hline \multicolumn{6}{|l|}{$\begin{array}{l}\text { Vybraní pracovníci naší organizace dostávají } \\
\text { atraktivní nabídky pracovních příležitostí. }\end{array}$} \\
\hline \multicolumn{6}{|l|}{$\begin{array}{l}\text { Naší pracovníci neodcházejí za nabídkou jiných } \\
\text { firem. }\end{array}$} \\
\hline $\begin{array}{l}\text { Moje organizace podporuje sdílení nápadů } \\
\text { a znalostí a jejich testování na všech } \\
\text { organizačních úrovních. }\end{array}$ & & & & & \\
\hline
\end{tabular}


Tab. 3 - pokračování

\begin{tabular}{|l|l|l|l|l|l|}
\hline \multicolumn{1}{|c|}{ Tvrzení } & $\begin{array}{c}\text { Silný } \\
\text { souhlas }\end{array}$ & Souhlas & Nesouhlas & $\begin{array}{c}\text { Silný } \\
\text { nesouhlas }\end{array}$ & $\begin{array}{c}\text { Nejsem } \\
\text { si jist(a) }\end{array}$ \\
\hline $\begin{array}{l}\text { Moje organizace plánovitě posiluje a podporuje } \\
\text { spolupráci. }\end{array}$ & & & & & \\
\hline $\begin{array}{l}\text { Moje organizace plánovitě podporuje } \\
\text { překračování bariér mezi funkcemi. }\end{array}$ & & & & & \\
\hline $\begin{array}{l}\text { Moje organizace podporuje spolupráci } \\
\text { sobchodními partnery. }\end{array}$ & & & & & \\
\hline $\begin{array}{l}\text { Moje organizace podporuje spolupráci se } \\
\text { zákazníky. }\end{array}$ & & & & & \\
\hline $\begin{array}{l}\text { Moje organizace podporuje spolupráci } \\
\text { s konkurenty. }\end{array}$ & & & & & \\
\hline $\begin{array}{l}\text { Lídři v naší organizaci sdílejí výsledky a důvody } \\
\text { neúspěchú konstruktivním způsobem, který } \\
\text { přispívá k organizačnímu učení. }\end{array}$ & & & & & \\
\hline $\begin{array}{l}\text { Moje organizace využívá úspěšné iniciativy } \\
\text { podporující práci se znalostmi. }\end{array}$ & & & & & \\
\hline
\end{tabular}

Zdroj: vlastní zpracování, 2020

Pokud v Tab. 3 převládají odpovědi Silný souhlas, Souhlas, můžete být spokojeni. U odpovědí Nesouhlas, Silný nesouhlas, Nejsem si jist(a) byste se měli zamyslet, co (a jak) v dané oblasti zlepšit.

\section{C.1.3 Metriky inovací}

Inovace jsou základním stavebním kamenem pro adaptaci na Společnost 4.0, budeme se tedy metrikami jejich hodnocení zabývat poněkud podrobněji. Metriky inovací jsou organizační metriky, které pomáhají klasifikovat inovační schopnost organizace a její úspěšnost. Jsou důležité z mnoha důvodů jak pro malou začínající firmu, tak pro stabilizovanou nadnárodní firmu, protože ovlivňují provoz firmy tím, že indikují, zda je v souladu se stanovenými cíli a zájmy, a pomáhají managerům přijímat rozhodnutí na základě objektivních dat.

Proces měření závisí na typu inovace a př́stupu podniku k měření úspěšnosti. Každá inovace je jiná a podniky mají různé priority, a proto se budou metody lišit. Některé se soustředí výlučně na kvantifikovatelné finanční ukazatele, jiné budou používat směs kvantitativních a kvalitativních ukazatelů.

Specifické, měřitelné a akční metriky inovací podporují inovační proces a vedou ke vzniku podstatně většího množství inovačních výstupů. Následující Obr. 1 ukazuje, proč jsou inovační metriky cenné. 
Obr. 1: Proč jsou inovační metriky cenné

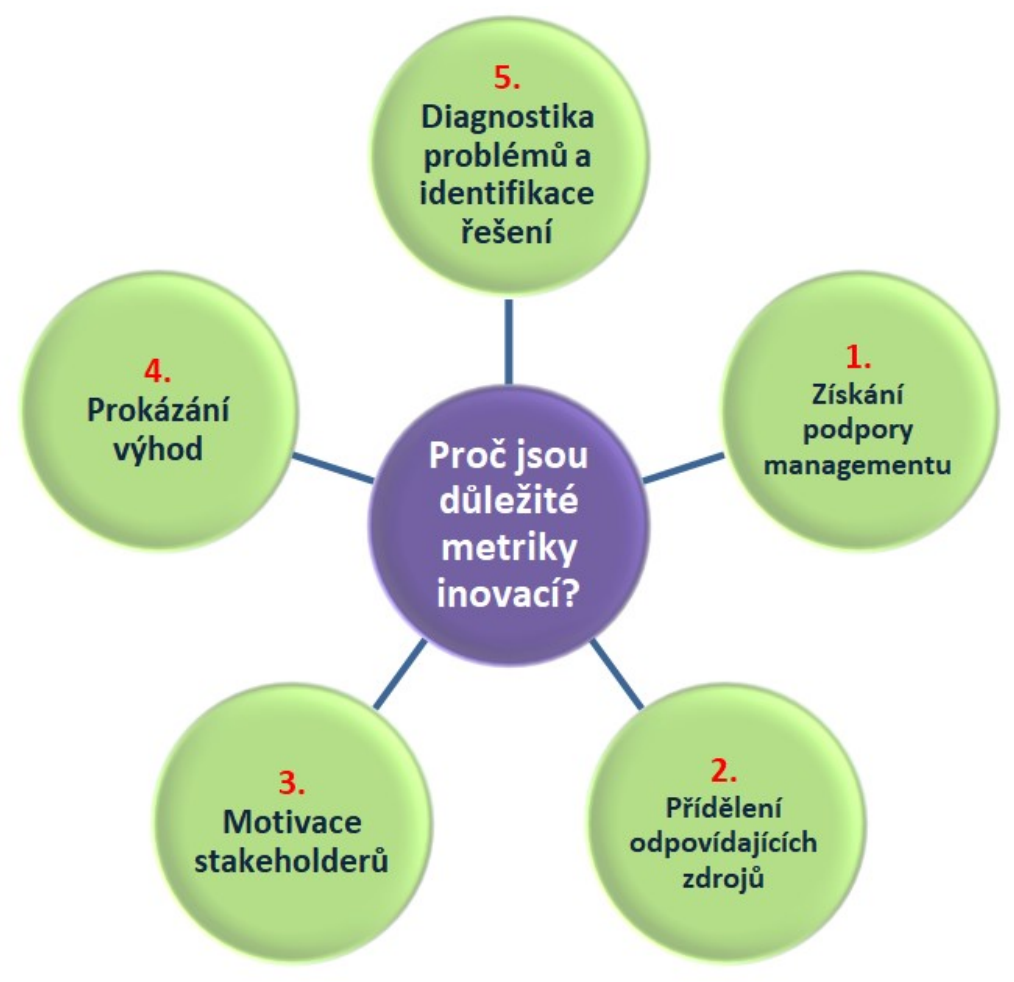

Zdroj: vlastní zpracování, 2020

Inovace mají tři rozdílné, ale související komponenty: vstupy, nebo zdroje, jako lidi a peníze, vstupují do procesů, které je transformují na výstupy, mezi něž patří jak finanční př́ijmy, tak neprímé výhody jako silnější značka a získané znalosti, které mohou být uplatněny $v$ jiných nabídkách. Všechny tři komponenty mohou - a měly by být - měřeny (BCG, 2006, p. 6).

Zastavte a zamyslete se: Jaké typy inovací potřebuje vaše organizace k dosažení svých cílů? Zkuste na základě svých inovačních cílů a strategie rozhodnout, čemu věnovat pozornost a co lze opominout. Začněte sledovat alespoň některé dále uvedené metriky. Nezapomeňte, že nejdůležitější je vyváženost metrik uvnitř třech kategorií a mezi nimi.

\section{Můžete měřit např. následující vstupy:}

- Přidělené finanční zdroje: Podnikové finance, fondy, úvěry, dotace, kapitál, atd.

- Lidské zdroje: Určitě budete sledovat počet lidí, kteří se inovací zabývají. Ještě důležitější je ale sledovat počet zastoupených kličových pracovníků. Musíte vědět, proč a kde tráví svůj čas.

- Počet vytvořených nápadů a očekávaný zisk. Nápady jsou důležitým vstupem - jsou palivem pro inovace. I když si mnoho firem myslí, že mají nedostatek nápadů, většinou tomu tak není. Nicméně - pokud to nezměříte, nikdy nebudete mít jistotu. A pokud se skutečně ukáže, že nemáte dost skutečně vynikajících nápadů, musíte vědět, co dělat, abyste tento nedostatek odstranili.

- Náklady na výzkum a vývoj (V\&V). Kolik váš podnik investuje ročně do získání externích výsledků V\&V? 


\section{Pro procesy můžete měřit:}

Zdroje spotřebované jednotlivými projekty a jejich průměr. Proces musí být účelný i účinný. Většina podniků umí měřit účinnost, takže tím můžete začít, ale musíte pokročit dál.

- Počet nápadů, které postupují z jedné fáze procesu do další. Jak funguje váš proces? Co se uvnitř něho děje v každém čase?

\section{Pro výstupy můžete měřit:}

- Počet nových produktů uvedených na trh. I když počet nových produktů není finančním výstupem, musíte vědět, co se děje na konci procesu.

- Př́růstek obratu a zisku. At jde o produktovou, procesní nebo marketingovou inovaci, musí pozitivně ovlivnit zisky.

- Návratnost investic (ROI, Return on Investment) vašich inovačních aktivit. To je, oč tu běží. Přináší náklady vynaložené na inovace dostatečný zisk? Jde o klíčovou metriku určující, kolik investovat do inovací.

- Nepřímé, nefinanční výstupy, které je důležité sledovat. Počet přiznaných patentů nebo ochranných známek, publikací, apod. může být mírou získaných znalostí.

\section{Uvědomte si, že ne všechny metriky inovací jsou kvantifikovatelné!}

Nejpoužívanější inovační metriky jsou:

- Procento ročních př́ijmů $\mathbf{z}$ nových produktů, uvedených na trh $\mathbf{v}$ posledních $\mathbf{N}$ letech. Tato metrika patří mezi nejpoužívanější.

- Náklady na V\&V. Tato metrika předpokládá, že objem prostředků vynaložených na V\&V je prímo úměrný počtu vytvořených inovativních produktů a procesů. Tento předpoklad je však v mnoha publikacích zpochybňován.

- Tvorba patentů (ochranných známek, copyrightů, publikací). Některé firmy podávají patent za patentem a chlubí se svou inovační výkonností. To je ale pravda jen pro některé z nich. Mnoho podniků své produkty a procesy nepatentuje a chrání je jako obchodní tajemství. Jakmile je patent vydán, stává se inovace dostupnou všem, kdo pátrají v patentové literatuře. Samotný počet patentů nezaručí vítězství nad konkurencí. Optimálním řešením je mít patenty, které přinášejí významnou hodnotu.

Neměli byste používat přiliš málo, ale ani přiliš mnoho metrik. Pokud jich sledujete př́liš mnoho, stojí to čas, práci a peníze. Experti doporučují používat 8 až 12 metrik.

Další informace k inovačním metrikám viz např. (VIIMA, 2020).

\section{C.1.4 U-SME Innovation}

V rámci projektu DESIGN OF A MODEL FOR JOINT UNIVERSITY - ENTERPRISE INNOVATION podpořeného programem Leonardo da Vinci byla na ZČU vypracována metodika hodnocení připravenosti firmy úspěšně implementovat inovační strategie. Výstupy tohoto projektu jsou př́stupné na www stránkách projektu (ZČU, 2004) včetně dotazníku, který je připraven prohodnocení připravenosti podniku kinovacím. Po vyplnění dotazníku vExcelu se zobrazí připravenost firmy $v$ šesti kategoriích a vygeneruje se návod $k$ dalšímu postupu. Metodika byla použita při zpracování kapitoly 6 publikace Inovace $v$ malém a středním podnikání (Žižka, Rydvalová a Jáč, 2005). 


\section{C.2 OPATŘENÍ PRO OBLAST INOVACÍ}

\section{C.2.1 Úvod}

Veškeré změny světa způsobené člověkem jsou výsledkem lidské snahy o něco nového. Touha zkusit něco nového je výraznou charakteristikou člověka. Nových nápadů je mnoho, ale cenu mají pouze tehdy, kdyžz z nich je vytvořena nová hodnota, čímž se stávají inovacemi.

Inovace je někdy založena na existujícím nápadu, konceptu nebo produktu a jeho vylepšení. Významné inovace ale často vyžadují překročit hranice toho, co již existuje, a príjít s úplně novou koncepcí. Strategické výhody můžeme dosáhnout pouze tím, že budeme lídry změn, a jediným způsobem, jak toho dosáhnout, je být inovativní.

Všechny firmy a organizace musí být inovativní, jen tak si zajistí konkurenceschopnost a budoucí příjmy. Inovace není výsadou high-tech firem. Některé podniky, zvláště malé a střední (MSP, SME), si ne vždy uvědomují, co je inovace a jak ji ř́dit. Každý jednotlivec, každý podnik, v každém odvětví, může být inovativní. Inovace je proces, Ize se ji naučit.

Je třeba si uvědomit, že ne všechny inovace jsou technologické. Mnoho důležitých inovací v historii byly inovace sociální: založení univerzity moderního typu iniciované Wilhelmem Humboldtem (mezi jejími absolventy je 55 nositelů Nobelovy ceny), zavedení systému sociálního zabezpečení Otto von Bismarckem, který ve svém důsledku vedl k sociálnímu smíru a odmítnutí revolucí jako prostředku zlepšení pozice dělníků, zdravotnický systém, který zachrání více lidských životů než úzce pojímaná medicína. Nelze se tedy omezit na zúžené pojetí Průmyslu 4.0. Dnes stojíme na prahu Společnosti 4.0, která povede k výrazným změnám ve všech oblastech lidské činnosti a stane se další v řadě velkých sociálních inovací, které sice budou mnohdy vycházet z nastupujících technologií, ale důležité bude si neustále uvědomovat socio-ekonomické, právní a etické souvislosti.

Tato subkapitola začíná stručným uvedením do teoretických základů managementu inovací. Nejen každý produkt, ale i každá firma prochází různými fázemi životního cyklu, v nichž inovace hraje důležitou roli. Jak uvidíme, pro úspěch inovace je důležitá její realizace a rožšírení (difuze). Při volbě inovační strategie mohou pomoci koncepty podnikatelských modelů. Každá inovace je projektem, proto se zde zmíníme i o základech projektového managementu včetně rízení rizik a změn. Cílovou skupinou metodiky jsou znalostně intenzivní firmy a znalosti jsou zásadní komponentou inovačních procesů, a proto se zmíníme i o základech managementu znalostí.

Nesmíme zapomenout na to, že nejdůležitějším aktivem firmy, zvláště pak znalostně intenzivní, jsou její lidé. To reflektuje i název knihy The Technology Fallacy: How People Are the Real Key to Digital Transformation (Kane, Phillips, Copulsky \& Andrus, 2019), v českém překladu Šalba technologie: Jak jsou lidé skutečným klíčem $\mathrm{k}$ digitální transformaci, která je výsledkem pětiletého výzkumu na MIT (Massachusetts Institute of Technology).

$\checkmark$ druhé části této subkapitoly se zaměříme na využití teoretických konceptů a modelů v adaptaci na podmínky Společnosti 4.0.

\section{C.2.2 Co je inovace}

Organizace pro ekonomickou spolupráci a rozvoj (OECD) a Evropská komise $(E C)$ v příručce pro sběr a interpretaci dat o inovacích Oslo manuál (OECD, 2018) zavádí následující definici inovace:

Inovace je zavedením nového nebo významně zlepšeného produktu (výrobku nebo služby), procesu, nového marketingového prístupu nebo nové organizační metody $\mathbf{v}$ podnikových postupech, organizaci práce nebo externích vztazích. 
Minimálním požadavkem na inovaci je to, že produkt, proces, marketingový přístup, organizační metoda musí být pro podnik nová (nebo výrazně zlepšená).

Inovace musí být realizována, implementována. Nový produkt musí být uveden na trh, nový proces, marketingový přístup, organizační metoda musí být zavedeny do praxe podniku.

Některé podniky využívají dobře strukturované inovační projekty vývoje a komercializace nových produktů, jiné dávají přednost spojitému vylepšování svých produktů, procesů a operací. Oba typy podniků mohou být inovativní, inovace může být založena na jedné významné změně nebo raadě menších postupných změn.

Inovace je pro malé podniky životně důležitá. Je živnou silou každého úspěšného malého podniku, pomáhá mu uspět. Inovativní firma je taková, která ve sledovaném období implementovala nějakou inovaci.

V přístích letech budou vítězit podniky, které zabudují inovace mezi své klíčové schopnosti (core capability).

I když vy neinovujete, vaše konkurence ano. Pokud neinovujete, můžete konkurovat pouze cenou, a i to pouze dočasně.

Inovace je nerozlučně spjata spodnikatelstvím (entrepreneurship), což je zvýrazněno vjedné z nejlepších učebnic managementu inovací Innovation and Entrepreneurship (Tidd \& Bessant, 2011). Je třeba si uvědomit, že pojmy business a entrepreneurhip jsou obvykle překládány do češtiny jako podnikání, ale jde o zcela odlišné koncepty.

\section{C.2.3 Proč je inovace důležitá?}

Konkurenceschopnost a výkonnost firmy je silně závislá na úspěšné inovaci. Inovace je klíčovou hnací silou ekonomického rozvoje a přináší další výhody. Nápady a objevy zvyšují naši životní úroveň. Inovace může přispět i ke zvýšení bezpečnosti, zlepšení zdravotní péče, zvýšení kvality produktů a kzavedení produktů přátelštějších k životnímu prostředí. Inovace umožnila výrazné zvýšení produktivity a výrazně změnila způsob našeho života. Inovace a vzdělání jsou klíčovými podmínkami úspěchu ve znalostní ekonomice.

Rychle se měnící svět nabízí podnikům mnoho výzev a přiležitostí a inovace jim mohou pomoci k úspěchu. Měnící se požadavky a očekávání zákazníků, konkurence, technologie, legislativní prostředí a trh, který je $v$ rostoucí míre globalizovaný a dynamický - to vše vytvárí přiležitosti pro inovace. Inovace může snižit výrobní náklady, získat nové trhy a zvýšit konkurenceschopnost. Vytváŕí zisk, nová pracovní místa, zvyšuje podíl na trhu, a tak se stává hnací silou výkonnosti. Obr. 2 shrnuje výhody, které inovace podniku přináší. 
Obr. 2: Výhody, které inovace podniku přináší

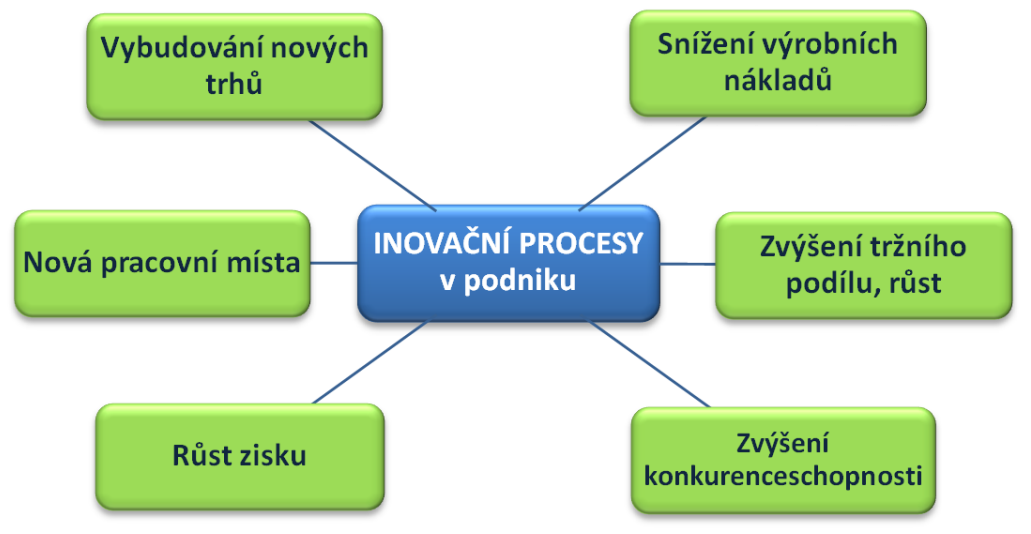

Zdroj: vlastní zpracování, 2020

\section{C.2.4 Čtyři hlavní typy inovací (podle předmětu inovace)}

Pokud jde o předmět inovace, rozlišuje Oslo Manual čtyři typy inovací: produktová inovace, procesní inovace, marketingová inovace a organizační inovace.

- Produktová inovace je zavedením nového produktu (výrobku nebo služby), jehož charakteristiky nebo možné užití jsou nové nebo výrazně zlepšené. Patři sem výrazná zlepšení technických specifikací, komponent a materiálu, zabudovaného software, uživatelského rozhraní a dalších funkčních charakteristik.

Přiklady produktových inovací: první přenosný MP3 přehrávač; zavedení brzdového systému ABS a další zlepšené subsystémy v automobilech, navigační systém GPS, mobilní telefon.

- Procesní inovace je zavedením nové nebo podstatně zlepšené metody výroby, poskytování služeb nebo distribuce. Patří sem podstatné změny postupư, technologie, zařizení a/nebo softwaru.

Př́klady procesních inovací: zařazení nového automatizovaného stroje do výrobní linky, zavedení počítačové podpory konstruování. Zavedení systému sledování zboží s pomocí čárových kódů nebo RFID (radiofrekvenční identifikace).

- Marketingová inovace je zavedením nové marketingové metody včetně podstatných změn designu nebo balení výrobku, umístění výrobku na trhu, propagace výrobku nebo stanovení ceny.

Přiklad: První použití podstatně odlišného media nebo techniky - jako propagace výrobku ve filmu nebo televizním programu - je marketingovou inovací.

- Organizační inovace je zavedením nové organizační metody do podnikových postupů, pracovních míst, organizačních a vnějších vztahů. Může být zaměřena na zvýšení výkonnosti podniku snižením administrativních nákladů, zlepšením pracovního prostředí (které vede ke zvýšení produktivity), získání př́stupu k neobchodovatelným aktivům (např. nekodifikované, tacitní znalosti) nebo snížením cen dodávek.

\section{C.2.5 Př́růstková, radikální a přelomová inovace}

- Př́růstková (inkrementální) inovace zahrnuje modifikace, zdokonalení, zjednodušení, konsolidaci, posílení stávajících produktů, procesů, marketingových a organizačních metod. Do této kategorie spadá většina inovací. Často jsou zaváděny v MSP; protože nejčastěji vycházejí z podnětů zákazníků, mají poměrně nízké riziko neúspěchu (existuje trh). 
Některé př́klady prírůstkových inovací:

- Mnohé verze tabletů, mobilních telefonů apod. nejsou originální, ale všechny modely vycházejí ze společné platformy.

- U většiny automobilů každoroční malá zlepšení vedla $k$ podstatnému zlepšení bezpečnosti, účinnosti a uživatelského komfortu.

- Radikální inovace zahrnuje zavedení radikálně nových výrobků nebo služeb, na jejichž základě vznikají nové podniky nebo celá odvětví, nebo které zpưsobují výrazné změny celých odvětví a vedou $k$ tvorbě nových hodnot. Radikální inovace většinou vznikají ve velkých firmách, nebot je u nich vyšší riziko neúspěchu (nemusí najít zákazníky), které by pro menší firmu bylo neúnosné.

Přiklady radikálních inovací:

- bankovnictví prodělalo řadu změn: bankomaty umožňují prístup $k$ účtu kdekoliv $v$ celém světě s pomocí jednoduché plastické karty.

- První laserové tiskárny vyvinuté firmou Xerox byly schopny vytisknout 60 listů za minutu s rozlišením 600 dpi (dots per inch) - Nikdo dř́ve nic takového nevyrobil!

- Přelomové inovace jsou překvapením. Dochází k nim na základě hlubokých výsledků ve vědě a technice. Ǩíkáme jim „přelomové“ proto, že jsou něčím, co většina lidí považovala za nemožné.

Přelomové inovace vytvářejí něco nového, nebo uspokojují nové potřeby. Jejich použití a důsledky často daleko přesahují původní záměry svých tvůrců. Mohou odstartovat vznik nových průmyslových odvětví, nebo transformovat stávající. Taleb (2011) pro ně zavedl termín „černá labut".

Přiklady přelomových inovací: Internet, web, GPS, mobilní telefony; antibiotika, očkování.

\section{C.2.6 Typy inovací podle strategie}

Inovace Ize podle firemní strategie rozdělit do dvou kategorií

- otevřené inovace a uzavřené inovace,

- udržitelné a disruptivní inovace.

Ve většině podniků dnes převládá koncept otevřené inovace (Chesbrough, 2006). Podnik využívající tuto strategii získává technologie, které potřebuje, z vnějšího prostředí a licencuje technologie, které vyvinul, ale nehodlá sám využívat. Otevřené inovace jsou postaveny na efektivním partnerství. Otevírají nové možnosti speciálně pro malé a střední podniky a jejich spolupráci s univerzitami a výzkumnými organizacemi. Důležitou roli hraje duševní vlastnictví a jeho ochrana.

Model uzavřených inovací převažoval po většinu 20. století. Podnik vychází z toho, že vůdcem trhu se stane podnik, který vkládá nejvíce prostředků do V\&V. Předpokládá, že zaměstnává ty nejlepší mozky v odvětví a tedy generuje, rozvíjí a komercializuje své vlastní nápady.

Christensen (2003) zavedl koncept disruptivní inovace, vycházející ze dvou předpokladů:

- Absorpční kapacita zákazníků na každém trhu je omezená;

- Technologický pokrok je obvykle rychlejší než schopnost trhu ho využít.

Zatímco tradiční, zavedené firmy se často zaměřují na udržitelnou inovaci a nabízejí lepší produkty, které mohou být nabízeny s vyšší marží, disruptoři komercializují jednodušší, lépe přizpůsobené produkty méně náročným uživatelům. Časem trajektorie disruptivní inovace protne požadavky náročnějších uživatelů a disruptor často vytlačí dřive úspěšné konkurenty z trhu. 
Tento model je ilustrován na Obr. 3.

Obr. 3: Model disruptivních inovací

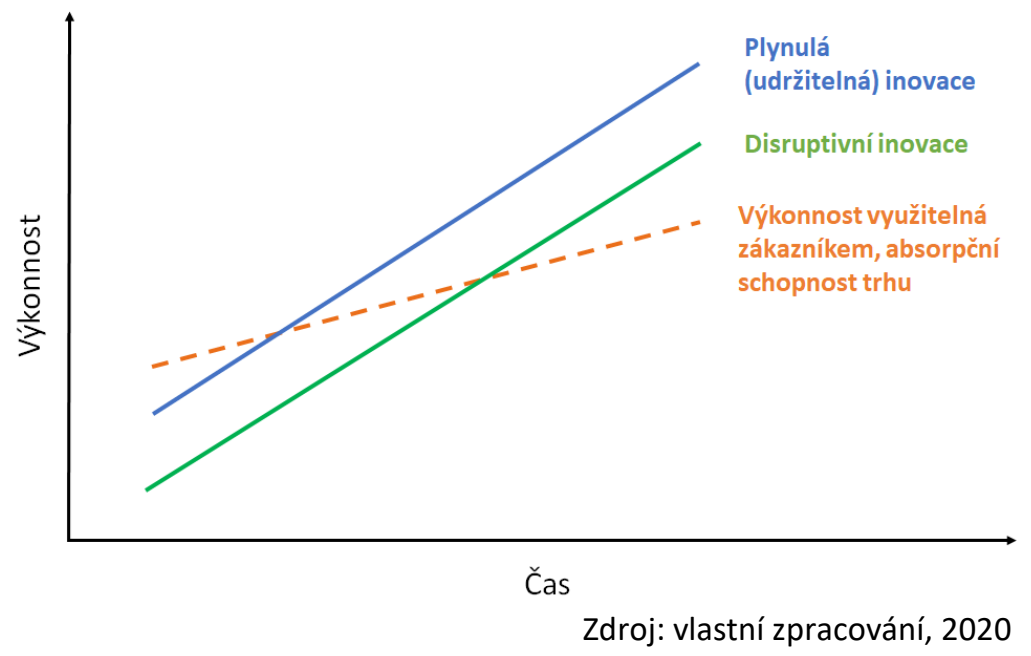

\section{C.2.7 Inovace v životním cyklu produktu}

Každý produkt (výrobek či služba) prochází určitým životním cyklem. Řízení životního cyklu je jednou z klíčových úloh řizení marketingu a prodeje. Níže znázorněný model popisuje vztah mezi objemem prodejů a ziskem z produktu. Model vymezuje pět fází života produktu:

- Vývojová fáze - produkt je vyvíjen, dosud není na trhu, existují pouze náklady (tj. zisk je záporný),

- Zaváděcí fáze - produkt je uveden na trh, prodeje pomalu rostou, zisk je stále záporný,

- Růstová fáze - zisk se dostává do kladných hodnot,

- Fáze zralosti - prodeje nadále rostou, ale zisk začíná klesat (klesá cena),

- Fáze úpadku - prodeje i zisk postupně klesají.

Obr. 4: Životní cyklus produktu

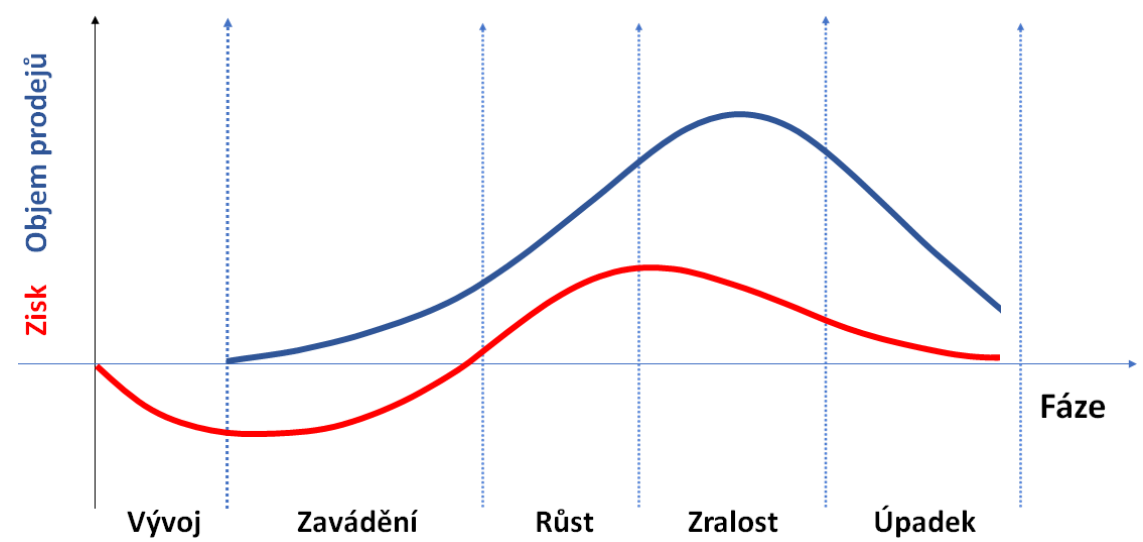

Zdroj: vlastní zpracování podle Synek, Kislingerová a kol., 2015 
V souvislosti s řizením životního cyklu se používá pojem Product Lifecycle Management.

Tento cyklus „„̌ivota“ produktu sestává z pěti fází, z nichž každá je individuálně dlouhá pro každý produkt. Je velmi důležité, aby management společnosti věděl, $v$ jaké fázi se produkt nachází a podle toho volil správnou strategii pro jeho co nejdelší udržení na trhu. Doporučuje se před uvedením nového výrobku na trh připravit kupující na produkt propagací a reklamou tak, aby byla poptávka po produktu nastartovaná již od začátku jeho umístění na trh.

Jaká je v tomto životním cyklu role inovací? Vývojová fáze začíná nápadem a jeho rozpracování je $\checkmark$ podstatě produktovou inovací. Součástí této fáze může být i rychlé prototypování. Po úspěšném překonání této fáze (nazývané také údolím smrti, nebot v řadě případů tato fáze úspěšně neskončí) je produkt uveden na trh, a pokud si získá dostatek zákazníků, začne generovat příjmy a v růstové fázi dosáhne bodu zlomu, $v$ němž se vyrovnají vložené náklady s př́immy plynoucími z prodeje, produkt začne generovat čistý zisk a dostane se do optimální fáze zralosti. Podnikatel však ví, že úspěch vzbudil pozornost konkurence a prirozeně nechce, aby se produkt dostal do fáze úpadku. Musí se tedy rozhodnout, jak se této fázi vyhnout, nebo ji alespoň oddálit. Dočasným řešením může být procesní inovace, která umožní snížení nákladů, takže produkt zůstává konkurenceschopný. Toto řešení však není dlouhodobě udržitelné. Proto je třeba ve fázi zralosti, kdy podnik má dostatek zdrojů, myslet na náhradu upadajícího produktu a pustit se do další produktové inovace.

\section{C.2.8 Difuze inovací}

Aby mohla inovace obstát, musí být osvojena velkým množstvím lidí. Difuze inovací je procesem jejich šíření ve společnosti $v$ průběhu času. Jde o proces, jehož rychlost a forma závisí na vlivu a kapacitě komunikačních kanálů a na připravenosti, schopnosti a ochotě př́ijemců inovace. Důležitý je prrínos inovace ve srovnání s existujícím stavem, kompatibilita se stávajícími technologiemi a zkušenostmi a obtížnost její implementace.

Model difuze inovací zavedl Rogers (2003). Vychází z předpokladu, že přijetí inovace má normální rozdělení různých typů uživatelů v závislosti na čase jejího přijetí, viz Obr. 5 a Tab. 2.

Obr. 5: Rozdělení osvojitelů inovací v Rogersově modelu

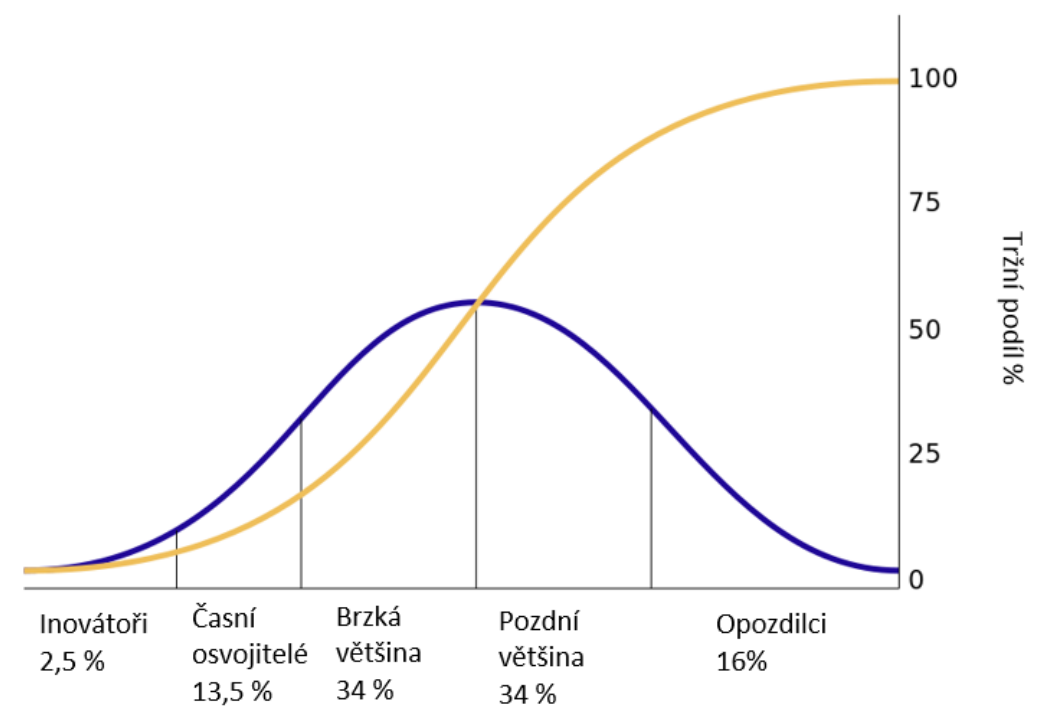

Zdroj: Wikipedia, 2019 
Pozn.: Žlutá křivka znázorňuje podíl inovace na trhu. Modrá křivka znázorňuje pořadí a tržní podíl jednotlivých kategorií inovátorů.

Jednotlivci se řadí do kategorií osvojitelů na základě toho, kdy začali aplikovat inovaci. Každý člověk může patřit u různých inovací do různých kategorií - viz Tab. 4.

Tab. 4: Kategorie osvojitelů v Rogersově modelu difuze inovací

\begin{tabular}{|l|l|}
\hline $\begin{array}{l}\text { Kategorie } \\
\text { osvojitelů }\end{array}$ & \multicolumn{1}{c|}{ Definice } \\
\hline Inovátoři & $\begin{array}{l}\text { Inovátoři jsou podnikaví, odvážní a horliví zkoušet různé inovace. Mají dostatek peněz } \\
\text { na to, aby si mohli dovolit ztratit peníze, když je inovace neúspěšná. Mají schopnost } \\
\text { rozumět a aplikovat komplexní technické poznatky. Mají vysoký společenský status. }\end{array}$ \\
\hline $\begin{array}{l}\text { Časní } \\
\text { osvojitelé }\end{array}$ & $\begin{array}{l}\text { Tato skupina má ze všech společenských systémů největší schopnost ovlivňovat názory } \\
\text { jiných lidí. Společnost je vnímá jako vážené. Potenciální osvojitelé je vyhledávají, aby se } \\
\text { s nimi poradili a získali potřebné informace. Jsou taktní a moudří. }\end{array}$ \\
\hline $\begin{array}{l}\text { Brzká } \\
\text { většina }\end{array}$ & $\begin{array}{l}\text { Tito lidé si osvojují inovace o něco dříve než průměr. Víc přicházejí do styku s vrstevníky } \\
\text { a málokdy jsou na vedoucích pozicích. Trvá jim delší čas, než se rozhodnou. Jsou } \\
\text { důležitou částí procesu difuze, protože fungují jako spojka mezi časnými osvojiteli } \\
\text { a pozdní většinou. }\end{array}$ \\
\hline $\begin{array}{l}\text { Pozdní } \\
\text { většina }\end{array}$ & $\begin{array}{l}\text { Osvojují si inovaci později než průměr. Neosvojí si inovaci, dokud si ji většina neosvojila. } \\
\text { Vyčkávají, dokud nejsou nejistoty o inovaci pryč. K osvojení je motivují systémové normy } \\
\text { a tlak okolí. }\end{array}$ \\
\hline Opozdilci & $\begin{array}{l}\text { Mají nejmenší rozhled ze všech skupin. Jsou sociálně izolováni. Mají tradiční hodnoty } \\
\text { a často se odvolávají na minulost. Jsou podezřivaví a může se stát, že když se ztotožní } \\
\text { s inovací, tak už existuje novější. }\end{array}$ \\
\hline
\end{tabular}

Zdroj: Wikipedia, 2019

Pro úspěch inovace je důležité podchytit první dvě kategorie. Do kategorie inovátorů patři podle von Hippela (Churchill, von Hippel \& Somack, 2009) tzv. vedoucí uživatelé (lead users), kteří se na každou inovaci těší. Tito uživatelé jsou ochotni produkt vyzkoušet a poskytnout rychlou zpětnou vazbu, která může být použita $\mathrm{k}$ jeho vylepšení, např. v př́ípadě softwaru jde o testování beta verzí. Mezi těmito uživateli jsou často i lidé, kteři vymyslí něco, co ještě není na trhu, často jde o způsoby trávení volného času (paragliding, zorbing apod.). Teprve poté se jejich nápadu chopí nějaká firma. Tento typ uživatelů může být zahrnut do tzv. rozšířeného podniku (extended enterprise) a přispět tak ke zvýšení jeho inovační schopnosti.

$\checkmark$ této souvislosti se můžeme zmínit i o konceptu rychlého prototypování: v případě produktových inovací je účelné co nejdřive vytvořit prototyp nebo tzv. minimální životaschopný produkt (minimum viable product, MVP), který nemusí být plně funkční, ale umožňuje rychlé testování designu potenciálními uživateli a následné úpravy. $\mathrm{V}$ prípadě fyzických produktů tvorbu prototypů výrazně usnadňuje 3D tisk.

\section{C.2.9 Podnikatelský model}

Podnikatelský model je nástrojem, jímž podnik popisuje proces tvorby hodnoty. Jeho účelem je:

- Zformulovat nabídku hodnoty, tj. hodnoty, kterou pro uživatele vytváří produkt založený na př́slušné technologii (produktem zde rozumíme jak výrobek, tak službu). 
- Identifikovat segment trhu, tj. uživatele, pro které technologie přináší užitek a účel, pro který bude používána.

- Definovat strukturu hodnotového řetězce, potřebného pro vytvoření a distribuci produktu. Vytvoření hodnoty je nutnou, ale nikoliv postačující podmínkou tvorby zisku; schopnost vytváření hodnoty závisí na:

- rovnováze sil mezi podnikem, dodavateli a konkurenty,

- $\quad$ na prítomnosti komplementárních aktiv (např. ve výrobě, distribuci, apod.) potřebných pro podporu pozice podniku $v$ tomto hodnotovém řetězci.

- Specifikovat mechanismus tvorby zisku a odhadnout strukturu nákladů a cílovou marži produktu.

- Popsat postavení podniku v hodnotové síti, která propojuje dodavatele a zákazníky, včetně identifikace potenciálních alternativních výrobců a konkurentů.

- Formulovat konkurenční strategii, která inovativní firmě pomůže získat a udržet konkurenční výhodu.

Je zřejmé, že podnik musí vytvářet hodnotu pro zákazníka. Vytvořit hodnotu pro zákazníka však nestačí: ke své udržitelnosti musí podnik vytvářet hodnotu i pro sebe (value appropriation).

Hodnota pro zákazníka (value creation) může být formulována v termínech „práce, která má být vykonána - Jobs to Be Done" (Christensen et al., 2016; Ulwick, 2017). Zákazník nekupuje produkt (výrobek nebo službu) proto, aby jej vlastnil, ale „pronajímá“ si ho, aby pro něj provedl důležité práce. Slovy profesora marketingu na Harvardu Teda Levittse, „lidé nechtějí čtvrtpalcový vrták, chtějí čtvrtpalcovou díru“. Lze dokonce doplnit - pokud chtějí např. pověsit obraz, nepotřebují ani díru, stačí dostatečně silné lepidlo. Christensen uvádí jako př́iklad úspěšnost hustého mléčného koktejlu (milkshake): jakou službu vykoná pro řidiče, kteří jedou ráno do práce? Průzkumem mezi řidiči, kteř́i si milkshake kupovali, bylo zjištěno: řidič se nestíhá před odjezdem z domova nasnídat, milkshake je výživný, cestou se tedy řidič nasnídá, nedrobí, a přitom mu zůstávají volné ruce k řizení (pije brčkem z kelímku v držáku v autě).

Při tvorbě podnikatelského modelu můžeme místo tradičních modelů zaměřených na soupeření s konkurencí vzít vúvahu i tzv. strategii modrého oceánu (Kim \& Mauborgne, 2009; Kim \& Mauborgne, 2004). Modrý oceán představuje tržní prostor, který ještě není známý. Modré oceány $\checkmark$ sobě skrývají dosud neobjevený a nevyužitý tržní potenciál a prostor. $V$ modrých oceánech se poptávka vytváŕí, místo aby se o ni bojovalo. Některé modré oceány mohou být vytvořeny mimo hranice existujících odvětví díky tomu, že hranice existujících odvětví se neustále rozšiřují. Konkurence není v modrých oceánech podstatná, nebot' zde ještě nejsou nastavena a určena pravidla konkurenční hry. Příkladem mohou být nízkonákladové aerolinie, slevové servery, Student Agency, kapslové kávovary a mnoho dalších.

Jednoduchým a přehledným nástrojem pro tvorbu podnikatelského modelu je plátno (schéma) Alexandera Osterwaldera a Yvese Pigneura (2015). Skládá se z devíti polí, která jsou základními stavebními kameny obchodního modelu. Odpovězte na následující otázky:

1. Segmenty zákazníků - Zákazníci jsou zdrojem př́ijmů podnikání. Kteří jsou vaši nejdůležitější zákazníci. Rozdělte je do skupin, které podrobněji popište (podle produktů, objemu prodejů, geografie apod.).

2. Nabízená hodnota - Popište, jaké problémy zákazníka řešíte a co užitím vašeho produktu nebo služby získá. Které hodnoty produktu uspokojuji potřebu zákazníka (jobs to be done)? 
3. Marketingové kanály - Jaké jsou vaše distribuční kanály. Jaké jsou jejich náklady? Jak mohou být integrovány do stávajících postupů vás i zákazníků?

4. Vztahy se zákazníkem - Jakým způsobem komunikujete se svými zákazníky a budujete s nimi dlouhodobé vztahy? Jaké vztahy očekávají vaši cíloví zákazníci a jak jich chcete dosáhnout? Jak mohou být integrovány do stávajících postupů vás i zákazníků?

5. Zdroje př́jmů - Jak a za co vaši zákazníci platí? Jaká je jejich platební morálka? Jaké způsoby plateb preferujete? Jak príispívá obrat z jednotlivých aktivit k celkovému obratu?

6. Klíčové zdroje - Určete, co všechno potřebujete, abyste mohli provádět klíčové činnosti. Patří sem fyzické zdroje, duševní zdroje, lidské zdroje a finanční zdroje.

7. Klíčové aktivity - Jaké jsou klíčové aktivity, s jejichž pomocí vyrábíte výrobky nebo poskytujete služby? Které z nich jsou nejdůležitější ve výrobě či službě, distribuci, vztazích se zákazníky apod.?

8. Klíčoví partneři - Kteří jsou vaši nejdůležitější partneři/dodavatelé? Co pro nás dělají, co děláme my pro ně? Jaká je motivace $\mathrm{k}$ vytváření/udržení/rozvoji partnerství?

9. Náklady - Jaké jsou vaše nejdůležitější náklady? Které klíčové zdroje/aktivity jsou nejnákladnější?

Plátno (schéma) podnikatelského modelu, vytvořené podle originálního schématu Osterwaldera a Pigneura, je uvedeno v Príloze 1.

Po provedení úvodní analýzy prodiskutujte návrh se svým týmem, např. s pomocí brainstormingu. Zamyslete se nad tím, jaké další hodnoty byste mohli nabídnout, jak lépe uspokojit zákazníky, jak získat nové trhy, jací partneři by vám pomohli v dalším rozvoji, jaké jsou podnikatelské modely konkurentů a podobně. Taková diskuse vám pomůže zlepšit výchozí návrh, obohatit ho novými nápady.

Ash Maurya (2012) toto schéma upravil pro start-upy pod názvem Lean Canvas. Popisuje důvody, které ho vedly $\mathrm{k}$ vytvoření tohoto modelu, a vysvětluje rozdíly mezi originálním a štíhlým plátnem, viz Př́loha 2.

Stejně jako u originálního plátna postupujeme tak, že vyplňujeme postupně jednotlivá pole.

1. Segmenty zákazníků.

2. První vlaštovky (Early Adopters) - zákazníci, se kterými jste testovali váš produkt a kteří jsou schopni a ochotni ho rychle přijmout.

3. Problémy - Nejdůležitější problémy, které chcete řešit.

Existující alternativy - jak jsou tyto problémy řešeny v současnosti.

4. Nabízená hodnota.

Proč by zákazníci měli mít zájem o váš produkt.

Známé analogie - jaká řešení jsou v současnosti nabízena.

5. Řešení - Jak budete řešit problémy identifikované v poli 3?

6. Marketingové kanály.

7. Zdroje př́ijmů.

8. Náklady.

9. Klíčové metriky.

10. Neférové výhody - co z vašeho modelu bude obtížné kopírovat, imitovat apod. 
Výhodou pláten je to, že jsou přehledná (1 strana), nutí podnikatele k promyšlení vazeb mezi různými aspekty a na jejich tvorbě se může podílet více lidí. Mohou být vytvořeny různé varianty modelů např. pro různé skupiny zákazníků a porovnány jejich př́nosy, př́íadně rizika. Vytvořené plátno lze použít jako východisko $k$ tvorbě podnikatelského plánu, ve kterém je model detailně rozpracován. Struktura podnikatelského plánu je zobrazena na Obr. 6.

\section{Obr. 6: Myšlenková mapa osnovy podnikatelského plánu}

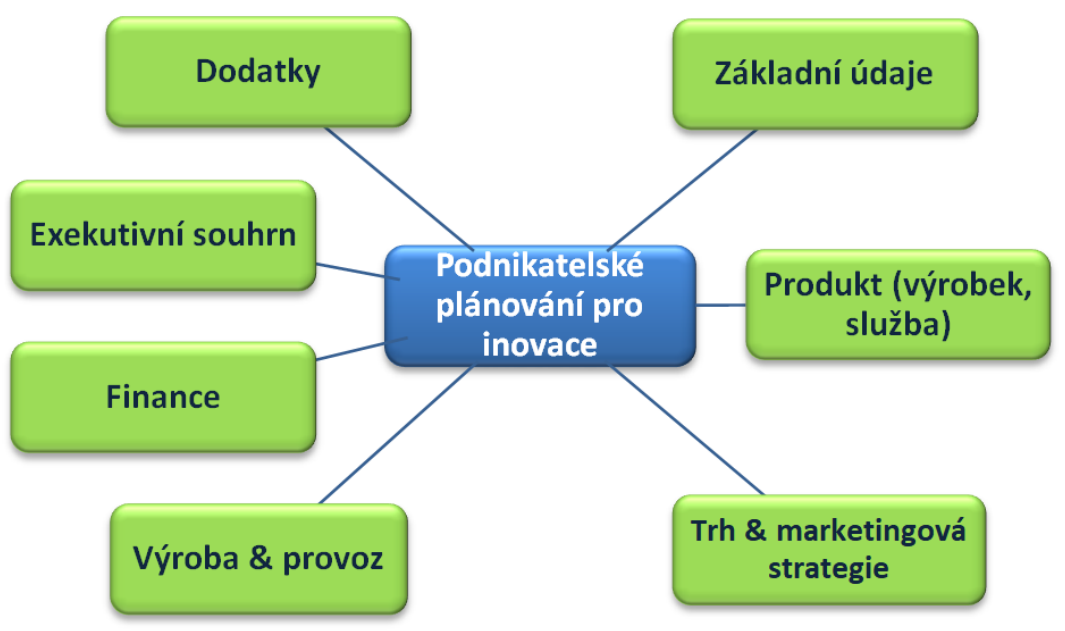

Zdroj: vlastní zpracování, 2020

Podrobnější návody k roli a tvorbě podnikatelského plánu a odkazy na další literaturu najdete např. v publikaci Základy podnikání (Pavlák, Novotný \& Vacek, 2017, kap. 6).

\section{C.2.10 Křivka úsměvu}

Zakladatel společnosti Acer Stan Shih analyzoval proces tvorby přidané hodnoty a zjistil, že nejvyšší přidanou hodnotu produktu tvoři výzkum a rozvoj a následné služby spojené s marketingem a prodejem, zatímco př́spěvek výroby $k$ přidané hodnotě je mnohem menší. Závislost přidané hodnoty na fázích produkčního řetězce znázornil v podobě tzv. křivky úsměvu (Smiling Curve), která je prezentována v Obr. 7.

\section{Obr. 7: Křivka úsměvu Stana Shiha}

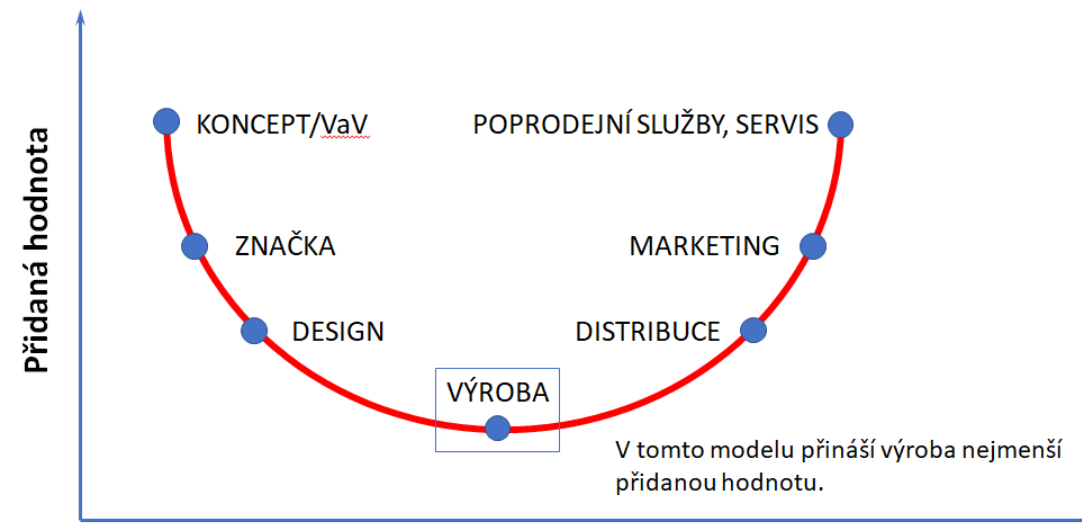

Produkční řetězec

Zdroj: vlastní zpracování podle Chaitravi, 2010 
Tato křivka ukazuje, že úspěšnost produktu $v$ termínech přidané hodnoty závisí převážně na předvýrobních a postvýrobních fázích, v nichž pracují specializovaní, kompetentní (a dobře placení) lidé.

Příkladem firmy využívající strategie založené na tomto modelu je Apple. Jádrem úspěchu je silná vize a unikátnost této společnosti a jejích produktů, vynikající image, propagace a služby. Většina výroby probíhá ve společností Foxconn s komponentami dodávanými dalšími firmami.

Srovnáme-li tuto křivku se strukturou ekonomiky ČR, zjistíme, že ta má obrácený průběh - je spíše zamračená: převažuje výroba nad před- a post- výrobními fázemi. Před ekonomikou ČR tedy stojí zásadní výzva - obrácení struktury ekonomiky tak, aby se dostala do shody s křivkou úsměvu. Koncepty Průmysl 4.0 a Společnost 4.0 dávají šanci tuto strukturu změnit a otvírají př́ležitosti pro znalostně orientované podniky.

\section{C.2.11 Inovace a projektový management}

Každá inovace splňuje tři základní charakteristiky projektu: unikátnost, časová omezenost a omezené zdroje. Je proto vhodné používat základní nástroje projektového managementu popsané $v$ mnoha publikacích, přehledný úvod včetně návodu k použití programu MS Project k plánování a sledování průběhu projektu najdete např. $v$ príručce pro studenty předmětu Projektové řízení na FEK ZČU (Vacek a kol., 2005), k dalšímu studiu můžeme doporučit knihy (Doležal a kol., 2016; Svozilová, 2016). Důležitou složkou řizení nejen projektů, ale i dalších aktivit, je řízení rizik, o kterém se podrobněji zmiňujeme $v$ dalším textu.

\section{C.2.12 Řízení rizik}

Řízení rizik je neoddělitelnou složkou podnikatelských aktivit. Riziko Ize definovat jako událost, která může ovlivnit podnik nebo některou z jeho aktivit. Hodnotíme ho podle pravděpodobnosti nastání a dopadu, pokud nastane. Tento dopad může být i pozitivní, pak mluvíme o príležitosti (viz např. SWOT analýza), termín riziko budeme dále používat pro události s negativním dopadem.

Prvním krokem řízení rizik je jejich identifikace: vytvoření seznamu potenciálních rizik s odhady jejich pravděpodobností a dopadů. Můžeme použít např. brainstorming, analogie, expertní odhady, kontrolní seznamy, SWOT analýza, diagram příčin a následků.

\section{Kvalitativní matice rizik}

Pravděpodobnosti a dopady obvykle nejdřive hodnotíme kvalitativně, nejčastěji $v$ pětistupňové stupnici, a zaznamenáváme je do matice rizik viz Obr. 8. 
Obr. 8: Kvalitativní matice rizik

\begin{tabular}{|l|l|l|l|l|l|}
\hline Pravděpodobnost & \multicolumn{5}{|c|}{ Riziko } \\
\hline \hline Velmi vysoká & & & & & \\
\hline Vysoká & & & & R1 & \\
\hline Střední & & R2 & & & \\
\hline Nízká & & & & R4 & \\
\hline Velmi nízká & & & R3 & & \\
\hline
\end{tabular}

\begin{tabular}{|l|l|}
\hline \multicolumn{2}{|c|}{ Závažnost rizika } \\
\hline & vysoké riziko \\
\hline & střední riziko \\
\hline & nízké riziko \\
\hline
\end{tabular}

Zdroj: vlastní zpracování, 2020

\section{Kvantitativní matice rizik}

V dalším kroku přiřadíme kvalitativním hodnocením kvantitativní hodnoty (viz Tab. 5) a celkovou závažnost rizika určíme vynásobením hodnot pravděpodobnosti a dopadu - viz Obr. 9.

Tab. 5: Přiřazení hodnot pravděpodobnosti a dopadu rizika

\begin{tabular}{|l|c|c|c|c|}
\hline \multirow{2}{*}{ Stupnice } & \multicolumn{2}{|c|}{ Pravděpodobnost } & A & B \\
\cline { 2 - 5 } & $\mathbf{0 , 0 - 1 , 0}$ & $\mathbf{1 - 5}$ & 1 & 1 \\
\hline Velmi nízká & $0,0-0,2$ & 1 & 2 & 2 \\
\hline Nízká & $0,2-0,4$ & 2 & 3 & 4 \\
\hline Střední & $0,4-0,6$ & 3 & 4 & 8 \\
\hline Vysoká & $0,6-0,8$ & 4 & 5 & 16 \\
\hline Velmi vysoká & $0,8-1,0$ & 5 & 5 & \\
\hline
\end{tabular}

Zdroj: vlastní zpracování, 2020

Pro pravděpodobnost můžeme volit stupnici $0-1$ nebo $1-5$, pro dopad můžeme použít stupnici $A$ (lineární), pokud se však vyskytují velice závažná rizika s malou pravděpodobností (např. pád dělníka z lešení), je vhodnější použít stupnici nelineární, např. geometrickou (B).

Obr. 9: Kvantitativní matice rizik

\begin{tabular}{|c|r|r|r|r|r|}
\hline Pravděpodobnost & \multicolumn{5}{|c|}{ Riziko } \\
\hline \hline 5 & 5 & 10 & 15 & 20 & 25 \\
\hline 4 & 4 & 8 & 12 & 16 & 20 \\
\hline 3 & 3 & 6 & 9 & 12 & 15 \\
\hline 2 & 2 & 4 & 6 & 8 & 10 \\
\hline 1 & 1 & 2 & 3 & 4 & 5 \\
\hline Dopad & 1 & 2 & 3 & 4 & 5 \\
\hline
\end{tabular}

Zdroj: vlastní zpracování, 2020 
Následuje návrh způsobu ošetření rizika, a to jednak preventivní - ve stádiu plánování se pokusíme o opatření, které povede ke snížení pravděpodobnosti a/nebo dopadu, a jednak následné - jakou akci provést, pokud k riziku došlo a chceme minimalizovat jeho dopad (pravděpodobnost už nemá smysl).

Možné metody preventivního ošetření rizika jsou:

- Vyhnutí se: vysoká pravděpodobnost, významný dopad. Extrémním případem je zamítnutí aktivity, projektu apod. Každý podnik by měl mít stanovenu hranici přijatelnosti rizika.

- Přenos: pravděpodobnost nízká, dopad kritický (pojištění, přenos na jiný subjekt).

- Zmírnění: velká pravděpodobnost, mírný dopad nebo závažnost rizika významná a ostatní strategie nejsou možné (vyhnout se riziku nedá a nikdo nás proti němu nepojistí).

- Přijmutí: není jiná možnost, jak riziko ošetřit (případně jsou tyto možnosti př́liš drahé) a zároveň riziko významně projekt neohrožuje.

- Pasivní: pouze monitorování - sledování, zda se náhodou nevyvine v závažnější riziko.

- Aktivní: kromě monitorování prípravné kroky pro případ, že riziko opravdu nastane. Ty mohou mít podobu např́klad rezerv zdrojů (finančních, lidských apod.).

Všechny výše uvedené kroky zaneseme do registru rizik spolu se stanovením tzv. vlastníků rizika (osoba, která zodpovídá za jejich monitorování a ošetření) a spouštěčů (signálů, že se k tomuto riziku přibližujeme a je čas provést preventivní zásah).

\section{C.2.13 Řízení změn}

Ve většině případů průběh jakékoliv činnosti neprobíhá podle plánu, bohužel častěji se setkáváme s negativními než pozitivními odchylkami. Pokud zjistíme, že se skutečný průběh od plánu liší, musíme připravit a realizovat potřebné změny. Podněty ke změnám mohou přicházet jak $z$ vnitřního, tak z vnějšího prostředí organizace.

Příklady podnětů ke změnám z vnitřního prostředí: dochází ke zpoždění proti plánu nebo $\mathrm{k}$ růstu nákladů, zhoršuje se produktivita, pracovní morálka apod. Ale i lepší výsledky než plánované, které se mohou stát podnětem např. k procesním inovacím.

Př́iklady podnětů ke změnám z vnějšího prostředí: změny v legislativě, změna požadavků zákazníků. Př́klad postupu řízení změn projektu je uveden na Obr. 10. 
Obr. 10: Proces řízení změny projektu

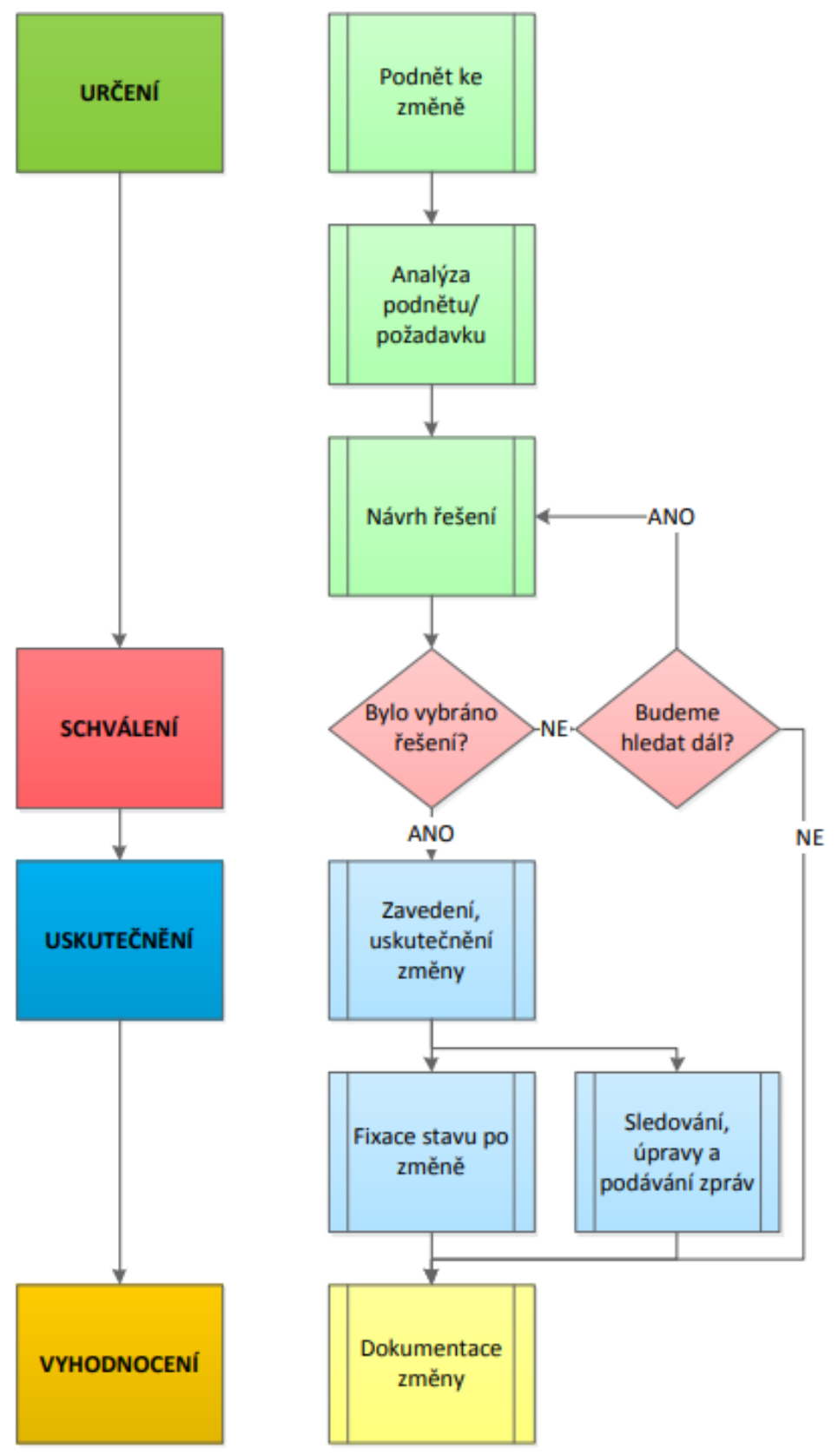

Jsme pozadu s realizací projektu oproti plánu, musíme něco udělat! ..."

„Co to znamená pozadu? O kolik? Opravdu musíme něco dělat? Co se stane, pokud to necháme být? Proč jsme se opozdili? ..."

„Jaké řešení se nabizí? Co musíme/můžeme udělat? Jak náročné jsou varianty $A, B, C$; co každá z nich přinese?..."

„Kdo má pravomoc provádět rozhodnutí? Podle čeho se bude vybírat nejlepší řešení? Vědí dotčené strany vše, co vědět mají? Vysvěttili jsme to všem? ..."

„Kdo to udělá? Do kdy? Jak poznáme, že je to uděláno dobře? Kdy to zkontrolujeme? ..."

„Postupujeme nyní podle prijatých změn? Není potřeba ještě něco poopravit? Jak vypadá zpětná vazba?..."

„Odnášíme si ponaučení? Co se podařilo, co přiště uděláme jinak? ..."

Zdroj: Cingl, 2012

\section{C.2.14 Znalosti}

Pro znalostně intenzivní firmy je práce se znalostmi základem jejich aktivit. Liebowitz (2009) definuje znalost následovně:

„Znalost je informace, která byla zorganizována a analyzována tak, aby byla srozumitelná a použitelná pro řešení problémů nebo rozhodování a učení. Organizační znalost je zpracovaná informace začleněná do postupů a procesů." 
Pro znalostní společnost, jakou se má stát Společnost 4.0, jsou myšlenky tím, čím byly fyzické zdroje pro průmyslový věk: zdrojem ekonomického rozvoje. Převládají otevřené inovace, pro něž je důležitá ochrana duševního vlastnictví. Musíme podporovat disruptivní inovace, které ohrožují existující rád, ale nadměrně přísný systém ochrany duševního vlastnictví může brzdit technologický pokrok. Nalezení správné rovnováhy je úkolem pro průmysl, politiky i veřejnost.

\section{Principy práce se znalostmi}

Globální konkurence, rostoucí požadavky zákazníků a turbulentní prostředí vedou k nutnosti flexibility, diferenciace, antifragility (Taleb, 2014), nabídky unikátní hodnoty. Inovace, v nichž hrají znalosti zásadní roli, jsou klíčovou hnací silou dlouhodobého rozvoje.

Znalosti jsou klíčem k výkonnosti, aktivitě a úspěchu organizace. Aby měly pro organizaci velký význam, musejí být formalizovány; pouze formalizované informace Ize reprezentovat digitálně, přenášet, sdílet a efektivně používat.

$\checkmark$ praxi je nutné znalosti integrovat $s$ metodami a modely. Mít znalosti jak získané zkušeností, tak metodologické, je cennější, než mít pouze jedny; učit se ze zkušenosti pomocí pokusů a chyb je živější, ale ne vždy efektivní. Lidé mají rovněž tendenci nadměrně zobecňovat na základě jedné nebo několika málo zkušeností. Pokud je to možné, může být výhodnější učit se od expertů, z knih a vkursech. Často je efektivnější učit se ze zkušenosti a z chyb jiných než vlastních, problém je, že málokdo je ochoten sdílet své neúspěchy. Je třeba vyvážit sběr a organizaci dostupných znalostí s učením se a vytvářením nových znalostí.

\section{Typy znalostí}

Rozlišujeme dva základní typy znalostí (Mládková, 2004):

- Tacitní (implicitní, embodied, tacit): vnitřní znalost, převážně v hlavách lidí; intuice - „víme víc, než dokážeme říci“.

- Explicitní

- Reprezentovaná, kodifikovaná: dokumenty, databáze, záznamy.

- Zabudovaná (embedded): zabudovaná v procesech, produktech, postupech.

Pro organizaci je výhodné, aby co nejvíce tacitních znalostí dokázala transformovat do znalostí explicitních, které Ize sdílet a zůstávají v organizaci i poté, co ji jejich původní nositel opustí. Cyklus transformace znalostí (model SECl - Socialization, Externalization, Combination, Internalization) je zobrazen na Obr. 11.

Obr. 11: Transformace znalostí

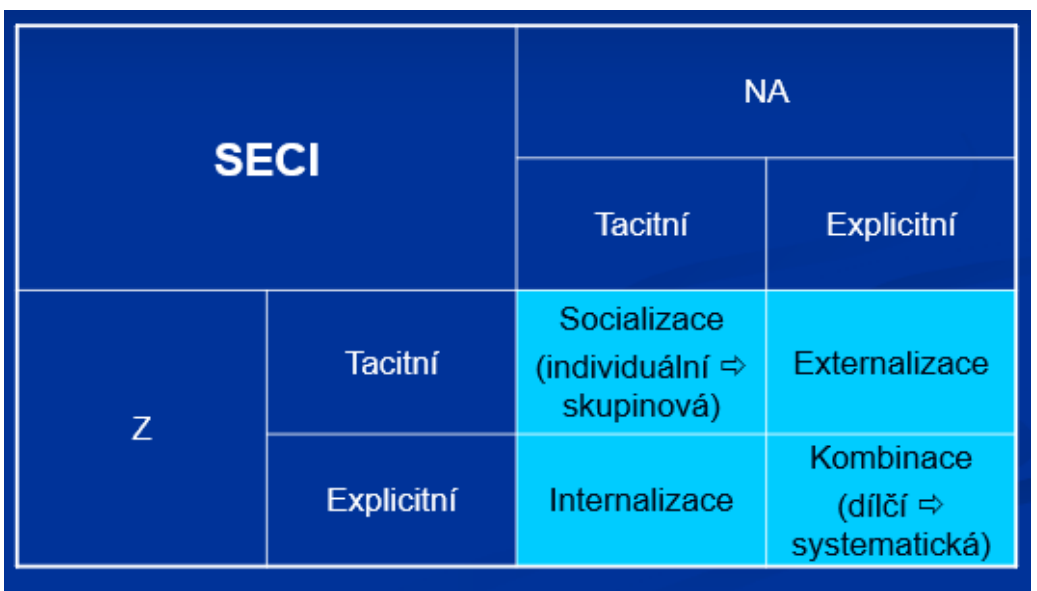

Zdroj: vlastní zpracování, 2020 
Peter Drucker zavedl pojem znalostního pracovníka jako takového, jehož práce je z větší části založená na znalostech, má (často jako jediný) znalost, která je pro organizaci důležitá a dokáže tuto znalost prakticky využít (Turriago-Hoyos et al., 2016). Taková znalost může být částečně podvědomá a ostatní k ní mají omezený př́stup - nemohou se ji naučit (chybí jim znalost nebo dovednost) nebo ji nemohou či nesmí použít (vazba na certifikát apod.). Často (ale ne nutně) jde o duševní práci.

Zatímco v industriální společnosti je moc spjata s hierarchickým postavením, je založena na formální autoritě, v postindustriální společnosti roste význam moci založené na znalostech: podřizení o své práci často vědí víc než jejich vedoucí, řízení pomocí úkolů a kontroly se stává iluzí, a moc je založená na spolupráci - tvorbě týmů a komunit, vytváření podmínek pro práci jednotlivců a týmů.

\section{Znalosti a produktivita}

Pro znalostně intenzivní firmy jsou typické následující aspekty:

- volba cíle práce - pracovník má na něj větší vliv a je výrazně aktivnější;

- autonomie a sebeřízení - sebeorganizace, sebekontrola, odpovědnost;

- nepřetržité inovace - rozvíjení znalostí;

- $\quad$ permanentní učení - osvojování a sdílení znalostí;

- $\quad$ kvalita práce - je obtížné určit konkrétní podíl jedince;

- nové pojetí práce - znalostní pracovník není nákladem, ale aktivem.

\section{Inovace a motivace}

Inovátoři nejlépe reagují na směs finančních a nefinančních pobídek. Většina talentovaných lidí potřebuje mít pocit dobrodružství, uznání tvrdé práce a dosažených úspěchů. Chtějí být hodnoceni, aby mohli prokázat to, čeho dosáhli.

Inovátoři jsou nejvíce motivováni následujícími faktory:

- Výzva;

- Osobní uznání;

- Svoboda činnosti;

- Finanční odměna.

\section{Řízení znalostí (Knowledge management, KM) a odměňování}

Organizace musí vytvořit systém odměňování, v němž úspěch jedince či skupiny znamená $i$ úspěch kolegů (Tab. 6).

Tab. 6: KM a odměňování

\begin{tabular}{|l|l|}
\hline Organizace by měla odměňovat: & Organizace by neměla odměňovat: \\
- Uspokojení zákazníka & - Svalování odpovědnosti na jiné \\
- Vysoký výkon & - Loajalitu k šéfovi \\
- Osobní znalosti a zkušenosti & - Konformitu a servilnost, pasivní \\
- Týmovou práci, sdílení znalostí & rezistenci \\
- a zkušeností & - Vnitřní konkurenci \\
- existujících znalostí a zkušeností & - Byrokratické chování \\
- Používání znalostí z archívu znalostí & - Touhu po moci, honbu za postavením \\
- Proaktivní řešení problémů a prevence & \\
\hline &
\end{tabular}




\section{Ochrana duševního vlastnictví}

Pro znalostní organizace obecně, a pro ty využívající model otevřených inovací zvláště, je mimořádně důležitá ochrana duševního vlastnictví (IPR - Intellectual Property Protection, (Vacek, 2005). Zastřešujícím orgánem pro ochranu duševního vlastnictví v ČR je Úřad průmyslového vlastnictví (ÚPV, 2020).

Dvě základní kategorie duševního vlastnictví jsou následující:

\section{Autorské právo}

- Autorská práva včetně počítačových programů.

- Práva související s právem autorským.

- Právo pořizovatele databáze.

\section{Průmyslové vlastnictví}

- Vynálezy.

- Užitné vzory.

- Průmyslové vzory.

- Topografie polovodičů.

- Nové způsoby prevence, diagnostiky a léčení lidí a zviŕat.

- Odrůdy rostlin a plemena zviŕat.

Problematika ochrany duševního vlastnictví je poměrně náročnou (a nákladnou) činností a pro většinu firem jde o outsourcovanou službu. Přesto lze doporučit, aby před zahájením inovačního projektu proběhla předběžná recenze na volně přístupných patentových databázích (Patent Databases, n.d.). Můžete tím předejít narušení práv držitele patentu, na druhou stranu mohou nalezené záznamy posloužit jako inspirace pro vaši další činnost (co už je chráněno vs. co chráněno není a kde je príležitost prijít s něčím novým).

Přehled základních právních předpisů upravujících právo duševního vlastnictví lze najít např. v publikacích Rába $(2005,2006)$, jeho licenčním využitím a oceňováním se zabývají Kubíček a Svačina (2006).

\section{C.2.15 Intelektuální kapitál}

Zpráva Ricardis (EC, 2006) se zabývá podporou měření a vykazování intelektuálního kapitálu v podnicích. Intelektuální kapitál se stává další důležitou složkou kapitálu podniku vedle tradičních složek hmotného a finančního kapitálu (viz Obr. 12). Zatímco pro hmotný a finanční kapitál jsou vypracovány a běžně používány standardizované metody hodnocení, pro intelektuální kapitál zatím taková metoda neexistuje, i když je zřejmé, že u předních firem tato složka hodnoty podniku často výrazně převyšuje hodnotu hmotného a finančního kapitálu (pokuste se odhadnout poměr účetní hodnoty firem jako Google, Microsoft, Apple k její tržní hodnotě vyjádřené cenou akcií).

Intelektuální kapitál se dále dělí na kapitál:

- $\quad$ Lidský - znalosti, dovednosti, zkušenost a kompetence zaměstnanců.

- Organizační - činnosti VaV, organizační předpisy, postupy a systémy, databáze a práva k duševnímu vlastnictví.

- Relační - vztahy s externími partnery (dodavatelé, zákazníci, partneři ve VaV, zapojení do sítí). 
Obr. 12: Složky kapitálu podniku

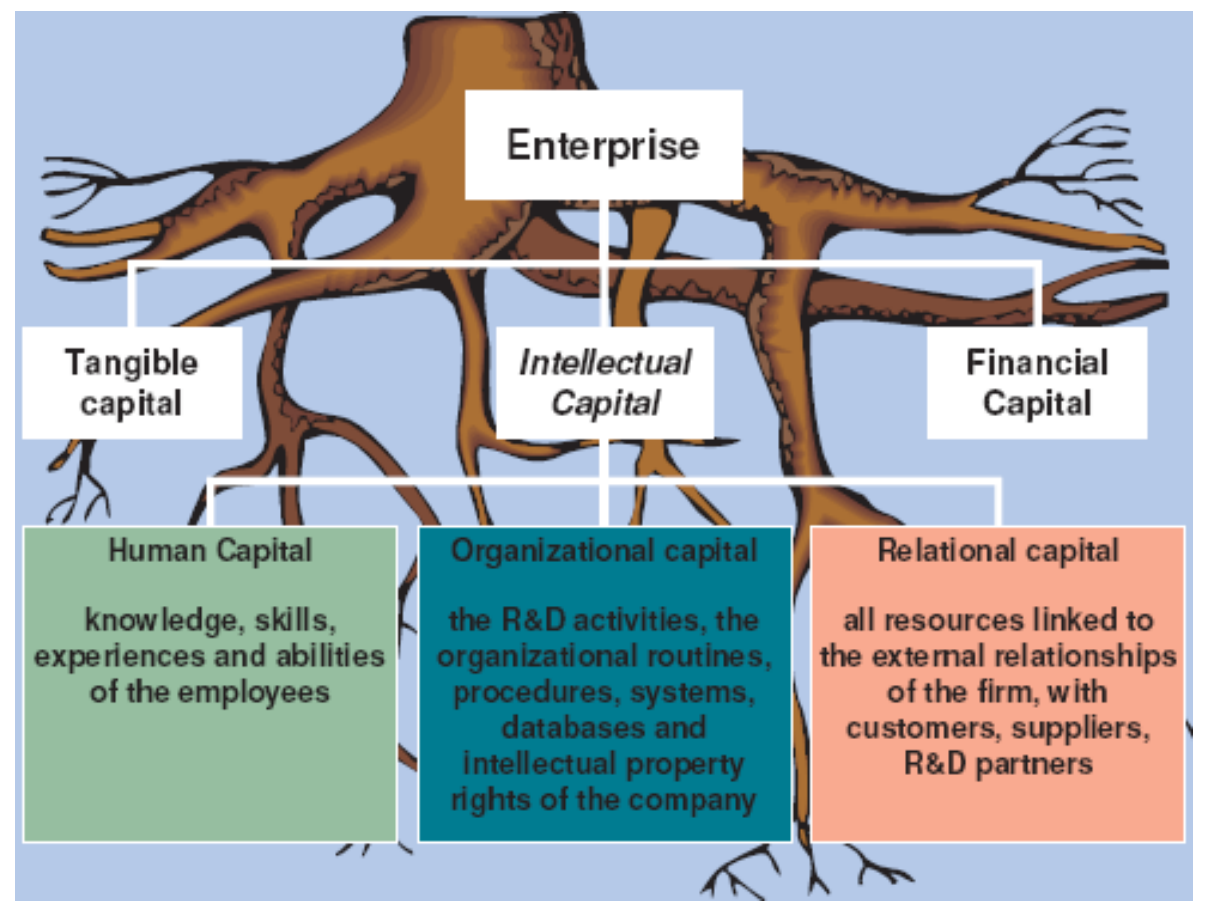

Zdroj: EC, 2006

Hodnota intelektuálního kapitálu je často rozhodujícím faktorem pro vstup investorů, zvláště rizikového kapitálu, do firmy.

\section{C.2.16 Jak se připravit na změny}

V kapitole 5 publikace Identifikace, analýza a hodnocení principů, postupů, metod a nástrojů pro adaptaci sektoru služeb na technické, ekonomické, sociální a environmentální podmínky Společnosti 4.0 (Vacek \& kol., 2019) jsou popsány technologie nastupující Společnosti 4.0. Zopakujme si zde jejich stručné charakteristiky a pokusme se je nyní propojit s koncepcemi uvedenými v předchozí části této kapitoly.

\section{- Umělá inteligence (Artificial Intelligence - Al)}

Softwarové algoritmy imitující lidské myšlení automatizují úlohy komplexního řešení problémů. Jejich podmnožina - strojové učení - se soustřed'uje na vývoj programů, které se učí z rozsáhlých souborů dat a přinášejí obrovský potenciál pro vývoj nových produktů a služeb, např. rozpoznávání obrazů, řečové technologie, technické překlady. Již dnes v některých oblastech nahrazuje činnosti dřive vykonávané lidmi (vyhodnocování snímků z lékařských vyšetření, hlasové ovládání různých zařízení, autonomní vozidla, podpora rozhodování apod.). Automatizují se rutinní úkoly jako účetnictví, ale nabízí se využití v mnoha dalších oblastech. Vedoucí právnické firmy používají Al ke skenování a vyhledávání právních dokumentů v čase několika minut místo dnešních týdnů a se zlomkem dnešních nákladů. Společnost Bloomberg využívá Al k tvorbě rutinních dokumentů bez lidského zásahu. Nové traktory a další zemědělské stroje mohou využít Al k mikrodávkování pesticidů a hnojiv i ke strojové sklizni plodin jako jahody, saláty apod.

Potenciál Al je obrovský - obrovské jsou ale i s tím spojené etické problémy.

Bude poptávka po lidech, kteří budou umět vyhledávat a zavádět nové aplikace a při vědomí jejich př́nosů a hrozeb hledat cesty etických inovací produktů a služeb s nižšími náklady a uvolnit 
lidi ke kreativnějším činnostem s vyšší přidanou hodnotou. Posud'te, v jakých aplikacích, v jaké míře a v jakém časovém horizontu by se tato technologie mohla uplatnit ve vaší firmě.

\section{- Rozšířená realita (Augmented Reality - AR), Virtuální realita (VR)}

Jde o audio a/nebo video prekrytí fyzické reality a její rozšíření, obohacení. Patří sem např. chytré brýle, které pomáhají ve skladech, na montážních linkách, v designu, při výcviku pracovníků a mnoha dalších aplikacích. $V$ třídimenzionálních simulacích generovaných počítačem mohou uživatelé $s$ použitím specializovaných zařizení interagovat $s$ virtuálními objekty. VR našla četné aplikace $v$ herním průmyslu, ale má potenciál transformovat další odvětví, např. při výcviku pracovníků pro práci $v$ nebezpečných situacích bez toho, aby byli vystaveni rizikům spojeným $s$ takovými situacemi v reálném světě. $V$ současnosti rychle roste jejich využití v herním průmyslu. Prolnutí fyzického a virtuálního světa přináší řadu nových možností pro inovace jak produktové (vývoj a výroba komponent, vývoj SW), tak procesní (simulace, testování). Jaké možnosti přináší tyto technologie vaší firmě?

\section{- Blockchain}

Blockchain je distribuovanou digitální databází, která využívá SW algoritmů ke spolehlivému a anonymizovanému zaznamenávání a ověřování transakcí. Záznamy událostí jsou sdílené mnoha stranami a jednou vložená informace nemůže být změněna. Dnes je tento pojem spojen hlavně $s$ digitálními měnami, může ale najít uplatnění v mnoha aplikacích, které vyžadují ověřitelnost transakcí, např. v logistických řetězcích, chráněné komunikaci v procesech s účastí zákazníků, podniků i veřejné správy. Vidíte ve své firmě prostor pro uplatnění této technologie?

\section{- Drony}

Kapacita a možnosti dronů závisí na jejich návrhu a konstrukci. Některé potřebují větší prostor ke startu, quadkoptéry mohou odstartovat vertikálně. Některé drony mohou být navigovány vzdáleným řízením, jiné jsou plně autonomní.

I když se již vyskytly případy, kdy drony ohrozily letecký provoz, mají před sebou široké spektrum použití. Dnes se testují drony $\mathrm{k}$ doručování zásilek, stále častěji jsou používány při řešení pojištovacích událostí, realitních činnostech, inspekcích staveb a v mnoha dalších aplikacích, u kterých existuje požadavek na ucelený pohled na určitý úsek terénu. Pomáhají i archeologům při mapování terénu a hledání stop po starých civilizacích, zemědělcům umožňují ucelený pohled na jejich pozemky. Významnou pomocí mohou být pro záchranné služby a nacházejí široké použití v armádě.

Nabízí se zde přiležitost jak pro produktové (návrh, výroba, rozšiřující moduly, ...), tak procesní (řizení a regulace dopravy, monitorování různých situací, mapování terénu, zásahy v havarijních situacích.

\section{- Internet věci - Internet of things (IoT)}

IoT je sit' fyzických objektů vybavených senzory a softwarem připojených na sít a výpočetní kapacitou, která jim umožňuje sbírat, sdílet a vyhodnocovat data, obvykle bez zásahu člověka. Zpracovává a analyzuje data sbíraná senzory, která mohou být dále využita pro optimalizaci procesů, preventivní údržbu, vzdálenou diagnostiku (jak strojů, tak např. lidí se zdravotními problémy - chytré náramky apod.) a podobné účely.

\section{- Robotika}

Roboti jsou dnes asi nejviditelnější a nejrozsáhlejší aplikací technologií Průmyslu 4.0 a často jsou považováni za skoro synonymum této koncepce. Jde o stroje vybavené čidly, řídícími prvky a inteligencí, které umožňují automatizaci činností, doplňují lidi a rož̌iřují jejich možnosti. Roboti, kteří byli vyvinuti primárně pro průmyslové aplikace, nacházejí stále širší pole působnosti např. ve 
zdravotnictví, sociálních službách apod. Tyto aplikace pomáhají zvládat výzvy prícházející z proměnného, neurčitého a nekontrolovatelného prostředí a mohou řešit problémy v prostředích pro člověka nebezpečných (radioaktivní záření, vysoké teploty nebo prašnost, práce se zdraví škodlivými látkami atd.).

Pokročilí roboti vycházejí za hranice továren a brzy najdeme agilní, učící se, lehké roboty ve službách $\mathrm{i} v$ domácnostech. $\mathrm{V}$ radě prípadů umožní lepší rozdělení práce - budou provádět opakující se, únavné nebo nebezpečné práce.

$\checkmark$ některých hotelových řetězcích již dnes roboti zastávají role poslíčků, testují se roboti jako osobní asistenti, mohou zastávat úklidové práce a široké uplatnění mohou najít v logistice (skladové hospodářství apod.).

Opět se zde nabízí př́ležitost pro produktové i procesní inovace.

\section{- 3-D tisk, aditivní výroba}

3-D tisk umožňuje vytváření 3D objektů z digitálních modelů postupným nakládáním vrstev materiálů, např. plastů, kovů a dalších materiálů, jako je třeba sklo a dokonce i beton. $S$ jeho pomocí lze vybudovat továrnu prakticky kdekoliv, nebudou se přepravovat fyzické objekty, ale jejich digitální předlohy. Technologie 3D tisku Ize s výhodou využít v tzv. rychlém prototypování, to je rychlém vzniku prototypů, které mohou být testovány a zdokonalovány již ve stádiu vývoje.

Za další větev aditivní výroby Ize považovat nanotechnologie, což jsou prakticky bezodpadové technologie stavějící objekty z atomů a molekul.

Shrnutí nástrojů Společnosti 4.0, které Ize použít v rámci optimalizace podnikových činností, uvádí následující Tab. 7.

Tab. 7: Nástroje Společnosti 4.0 využitelné k optimalizaci podnikových činností

\begin{tabular}{|c|c|c|c|c|}
\hline Nástroj & Zkratka & $\begin{array}{c}\text { Využití } \\
\text { (vybrané možnosti) }\end{array}$ & Pozitiva & Negativa \\
\hline $\begin{array}{l}\text { Umělá } \\
\text { inteligence }\end{array}$ & $A l$ & $\begin{array}{l}\text { - Prediktivní ŕízení zásob } \\
\text { (ERP systémy). } \\
\text { - Prediktivní údržba. } \\
\text { - Tvorba nových } \\
\text { obchodních modelů. }\end{array}$ & $\begin{array}{l}\text { - Automatizace } \\
\text { rutinních, opakujících } \\
\text { se úkolü. } \\
\text { - Možnost soustředit } \\
\text { se na řešení úkolů } \\
\text { s vyšší přidanou } \\
\text { hodnotou. } \\
\text { - Řešení nedostatku } \\
\text { pracovní síly. } \\
\text { - Urychlení činností } \\
\text { (předpoklad zadávání } \\
\text { hlasových povelů } \\
\text { namísto psaných). }\end{array}$ & $\begin{array}{l}\text { - Značná finanční } \\
\text { náročnost } \\
\text { výzkumu v dané } \\
\text { oblasti. } \\
\text { - Možnosti zneužití } \\
\text { výsledků } \\
\text { výzkumu. } \\
\text { - Nutnost } \\
\text { reorganizovat } \\
\text { zaběhlé } \\
\text { podnikové aktivity } \\
\text { a procesy } \\
\text { v souvislosti } \\
\text { s potřebou využití } \\
\text { Al. }\end{array}$ \\
\hline
\end{tabular}


Tab. 7-pokračování

\begin{tabular}{|c|c|c|c|c|}
\hline Nástroj & Zkratka & $\begin{array}{c}\text { Využití } \\
\text { (vybrané možnosti) }\end{array}$ & Pozitiva & Negativa \\
\hline $\begin{array}{l}\text { Virtuální } \\
\text { a rozšířená } \\
\text { realita }\end{array}$ & $V R, A R$ & $\begin{array}{l}\text { - } \text { Vizualizace } \\
\text { průmyslových zařízení. } \\
\text { - Lepší diagnostika } \\
\text { (lékařství). } \\
\text { - } \text { Navigace, ulehčení } \\
\text { orientace v prostoru. } \\
\text { - Trénink, učení se } \\
\text { (neomezené možnosti). }\end{array}$ & $\begin{array}{l}\text { - Operace (činnosti) } \\
\text { prováděné v reálném } \\
\text { čase. } \\
\text { - Nové způsoby } \\
\text { provádění „zažitých“ } \\
\text { činností (opravy } \\
\text { průmyslových } \\
\text { zařízení, navigace } \\
\text { v prostoru). } \\
\text { - Neomezené } \\
\text { možnosti učení. } \\
\text { - Větší emoční zážitek } \\
\text { pro spotřebitele. }\end{array}$ & $\begin{array}{l}\text { - Bariéry proniknutí } \\
\text { na trh. } \\
\text { - Vysoká cena. }\end{array}$ \\
\hline Block chain & - & $\begin{array}{l}\text { - Spolehlivé } \\
\text { a anonymizované } \\
\text { zaznamenávání } \\
\text { a ověřování transakcí. }\end{array}$ & $\begin{array}{l}\text { - Uplatnění } \\
\text { v logistických } \\
\text { řetězcích, chráněná } \\
\text { komunikace. }\end{array}$ & $\begin{array}{l}\text { - Nároky na } \\
\text { přenosovou } \\
\text { kapacitu } \\
\text { a pamět'ová } \\
\text { média. } \\
\text { - Nedostatek } \\
\text { kompetencí. }\end{array}$ \\
\hline Drony & - & $\begin{array}{l}\text { Doručování zásilek, } \\
\text { řešení pojišt́ovacích } \\
\text { událostí, realitní } \\
\text { činnosti, inspekce } \\
\text { staveb, mapování } \\
\text { terénu. }\end{array}$ & $\begin{array}{l}\text { - Inspekce a mapování } \\
\text { různých aktivit. }\end{array}$ & $\begin{array}{l}\text { - Zajištění } \\
\text { bezpečnosti, } \\
\text { regulace uživatelů. }\end{array}$ \\
\hline $\begin{array}{l}\text { Internet } \\
\text { věcí }\end{array}$ & IOT & $\begin{array}{l}\text { - Zpracování a analýza } \\
\text { dat sbíraných senzory. }\end{array}$ & $\begin{array}{l}\text { - Optimalizace } \\
\text { procesů, preventivní } \\
\text { údržba, vzdálená } \\
\text { diagnostika. }\end{array}$ & $\begin{array}{l}\text { - Vybudování } \\
\text { dostatečné } \\
\text { infrastruktury. }\end{array}$ \\
\hline Robotika & - & $\begin{array}{l}\text { - Automatizace činností, } \\
\text { rozšíření možností lidí. }\end{array}$ & $\begin{array}{l}\text { - Využití ve } \\
\text { zdravotnictví, } \\
\text { sociálních službách, } \\
\text { v prostředích pro } \\
\text { člověka } \\
\text { nebezpečných. } \\
\text { - Práce } 24 \text { hodin } 7 \text { dní } \\
\text { v týdnu, bez nemocí, } \\
\text { osobních konfliktů } \\
\text { apod. }\end{array}$ & $\begin{array}{l}\text { - Počáteční } \\
\text { investice, } \\
\text { zaškolení } \\
\text { pracovníků, } \\
\text { socioekonomické } \\
\text { důsledky. }\end{array}$ \\
\hline $\begin{array}{l}\text { 3-D tisk, } \\
\text { aditivní } \\
\text { výroba }\end{array}$ & - & $\begin{array}{l}\text { - } \quad \text { Vytváření 3D objektů } \\
\text { - } \text { digitálních modelů } \\
\text { postupným nakládáním } \\
\text { vrstev materiálů. } \\
\text { - } \quad \text { Nanotechnologie. }\end{array}$ & $\begin{array}{l}\text { - Výroba kdekoliv, } \\
\text { přenos datových } \\
\text { předloh místo } \\
\text { materiálních } \\
\text { produktů. } \\
\text { - Rychlé } \\
\text { prototypování. } \\
\text { - Bezodpadové } \\
\text { technologie. }\end{array}$ & $\begin{array}{l}\text { - Nutná } \\
\text { transformace } \\
\text { vývojových } \\
\text { a výrobních } \\
\text { procesů. } \\
\text { - Nedostatek } \\
\text { specialistů. }\end{array}$ \\
\hline
\end{tabular}




\section{Jak se uplatní tyto základní technologie?}

Výše popsané technologie se jako všechny technologie zdokonalují a nacházejí nová uplatnění. Jejich kombinací vznikají aplikace, které jsou schopnější než pouhý součet schopností jejich částí, vznikají synergické efekty a emergentní jevy. Můžeme loT senzory, které automaticky sbírají data o materiálech pohybujících se $v$ dodavatelském řetězci, propojit $s$ blockchainem, $v$ němž se vytvoří jedinečný a nezaměnitelný záznam přistupný každému účastníku dodavatelského řetězce. Video zachycené dronem může být zpracováno umělou inteligencí, abychom zjistili změny, ke kterým došlo od posledního záznamu.

Likens (2019) popisuje pět okruhů popisujících konvergenci výše popsaných technologií ke vzniku nových vln inovací:

- Zabudovaná umělá inteligence - Embodied AI

- Inteligentní automatizace - Intelligent Automation

- Automatizace důvěry - Automating Trust

- Konverzační rozhraní - Conversational Interfaces

- Rozšířená realita - Extended Reality

Zabudovaná umělá inteligence (Embodied AI). Technologie: 3-D tisk, Al, drony, loT, robotika

Al spolu se senzory je integrována $v$ mnoha produktech, od jednoduchých kamer po sofistikované drony, stále častěji ji najdeme i v domácích spotřebičích. Senzory sbírají data, která jsou zpracována algoritmy Al. Pohyblivé objekty (auta, drony) se mohou pohybovat autonomně, bez zásahu člověka. 3D tiskárny mohou v průběhu tisku modifikovat prototyp - zvolit pevnější nebo lehčí materiál, zvýšit efektivitu tisku. Je možná hlasová komunikace s robotem nebo konverzačním agentem. $V$ této oblasti Ize očekávat rychlý pokrok, na kterém se mohou podílet i malé a střední podniky (MSP).

Inteligentní automatizace. Technologie: Al, Robotic process automation (RPA)

Podniky začaly využívat automatizaci robotických procesů, aby racionalizovaly procesy a snízily náklady. Nástroje pro automatizaci (automation toolbox) se rozrůstají a stávají se chytřejšími. Patř́ mezi ně řečové technologie, strojové učení a další aplikace umožňující optimalizovat rozdělení práce, která je nejvhodnější pro lidi, a té, která je nejvhodnější pro stroje. Posun k inteligentní automatizaci přinese mnohem víc než úspory nákladů: vyšší hodnotu pro zákazníky, zlepšení podmínek práce zaměstnanců, zvýšenou kvalitu a procesní inovace.

\section{Automatizace důvěry. Technologie: Al, Blockchain, loT}

Kombinace blockchainu $s$ technologiemi jako Al nebo loT přináší možnost automatizace důvěry mezi uživateli $v$ síti. Např́klad loT umožňuje sledování palety $s$ potravinami z farmy do skladu obchodu. Senzory mohou ověřovat celý dodavatelský řetězec, takže se nejen ví, kde se paleta právě nachází, ale můžeme i vědět, zda na trase není př́liš horko, chladno nebo vlhko a podle toho případně upravit další transport. Blockchain vytvoří sít záznamů, která umožní kupujícím ověřit, že dostávají autentický produkt. Je možné ověřit, zda produkt, který obsahuje nebezpečné materiály, byl správně a bezpečně likvidován.

Konverzační rozhraní. Technologie: Al, loT, RPA, robotika

Technologie jako Al nebo robotika mění způsob práce $v$ továrnách, kancelárích i v terénu, ale jejich použití není vždy snadné. To se mění s novou generací rozhraní, jako jsou hlasoví a konverzační agenti, umožňující „bezešvou“ interakci uživatelů s technologií. Tato rozhraní činí systémy uživatelsky přátelštější a podniky, které je implementují do svých produktů, získají náskok před konkurencí.

Rychle se rozvíjející řečové technologie umožňují, že stále více zařízení bude s lidmi komunikovat prostřednictvím přirozené řeči, bez potřeby zadávat príkazy na klávesnici apod. Zdokonaluje se schopnost práce $v$ mnohojazykovém prostředí. To vše může výrazně usnadnit komunikaci člověk - 
stroj (a leckdy i člověk - člověk). Řečové technologie mohou převádět mluvenou řeč do textové formy a naopak. Textové dokumenty usnadňují vyhledávání a analýzu textů, převod textů do mluveného jazyka umožňuje př́stup $k$ dokumentům lidem se zhoršeným viděním nebo v prostředí, kde je obtižné pracovat s textovou formou, např. při jízdě autem.

\section{Rozšířená realita (extended reality, XR). Technologie: AI, AR, IoT, VR}

Tento termín zahrnuje kontinuum mezi jednoduchými digitálními zobrazeními a plně imersivním digitálním prostředím. Pravá síla těchto technologií je v jejich propojení s technologiemi jako Al a loT k vytvoření HW a SW systémů, které výrazně posilují produktivitu lidí. Je např. možné simulovat práci montérů a opravářů složitých zařízení na virtuálním 3-D objektu. Podobně jako letové simulátory používané $\mathrm{k}$ výcviku pilotů mohou být vytvořeny simulátory pro výcvik operátorů složitých a/nebo nebezpečných zařízení, ale i pro optimalizaci různých procesů.

\section{Nastupující technologie, konvergence technologií}

Tucker (2019) uvádí přehled technologií, které jsou připraveny k širšímu využití a přecházejí z vývojové do aplikační fáze. Mohou být využity jako inovační nástroje i v MSP. Tyto technologie mohou pomoci získat nové zákazníky, inovovat existující produkty nebo vymýšlet zcela nové, zvyšovat produktivitu zaměstnanců a otvírat nové cesty do budoucnosti. $V$ této subkapitole se pokoušíme uvést některé príklady využití těchto technologií v praxi.

\section{$5 G$ už přichází}

Předpokládá se, že tato technologie bude dostupná v několika nejbližších letech, pilotní provoz už leckde probíhá. Bude 10x rychlejší než současná $4 G$ a umožní připojení odkudkoliv, stahovat velké objemy dat. Může se stát hnacím motorem inovací v mnoha odvětvích a profesích. Kombinace rychlosti, doby odezvy a dosahu se stane katalyzátorem rozvoje technologií, jako jsou samořiditelná auta, telemedicina, big data, drony, virtuální realita a internet věcí a služeb. Studie 20 odvětví, která může ovlivnit $5 G$ je prezentována platformou CB Insights (2019).

\section{Aplikace (Apps)}

Aplikace se stávají nástrojem tvorby přidané hodnoty pro zákazníky a zvyšování produktivity. Mohou zákazníky zavést ke službě, kterou vyhledávají (restaurace, kultura, tankování, zdravotníci atd.), mohou pomoci při řešení havarijních situací včetně pojištění, řízení skladů a sběru dat, která mohou dát lepší informace o preferencích zákazníků. Je možné udělat snímek neznámého objektu (zvířete, rostliny) a rychle získat odezvu ve formě jeho identifikace. Mohou působit jako průvodci v muzeích, galeriích i v prrírodě a podávat zájemcům informace odstupňované podle požadovaných detailů.

\section{Nositelné technologie (wearable technology)}

Velké festivaly, sportovní a kulturní události často navštěvují stovky i tisíce návštěvníkủ. Ti mají často možnost mnoha voleb a mohou se cítit zmateni. Návštěvnicí však mohou dostat náramek synchronizovaný s aplikací v jejich smartphonech, který jim pomůže se orientovat a získat přístup k dalším nabízeným službám (občerstvení apod.).

\section{Big data}

Divíte se, proč mnohé franchisové řetězce otevírají své pobočky blízko u sebe? Používají totiž big data k tomu, aby zjistily, kde jsou př́ležitosti k zisku bez toho, aby si navzájem konkurovaly a přetahovaly zákazníky. Big data už nejsou doménou pouze velkých firem. Sbírá se čím dál tím víc dat, a proto i malé a střední firmy mohou využít síly datové analytiky k vytvoření strategické výhody: snízení nákladů a cen, nalezení nových cest na trh, personalizace nabídky. Big data a technologie jejich analýzy umožňuji analyzovat více zdrojů, než bylo kdykoliv dřive představitelné, a tak podporovat rozhodovací procesy. 


\section{C.2.17 Př́klady využití}

\section{Znalostně náročné aktivity v softwarových firmách}

Výzkum a vývoj v softwarových firmách je orientován na řešení problémů: začíná identifikací potřeb a požadavků zákazníků a pokračuje vývojem řešení, která budou zákaznicky přizpůsobitelná a škálovatelná. Inovační podněty jsou získávány jak interně, např. z technických a marketingových útvarů, tak př́mo od zákazníků. Velký význam má zpětná vazba od uživatelů. Často na začátku procesu vývoje nové aplikace není vždy možné (a často ani žádoucí) přesně definovat požadovaný koncový produkt, což požaduje tradiční vodopádový způsob řízení projektů, proto vypracovali vývojáři software metodiku agilního řízení projektů, která se posléze rozšírila i do dalších odvětví. Důležitou roli hraje prostředí podporující spolupráci s velkými firmami a networking. Význam externích služeb obvykle roste v pozdějších fázích vývojových projektů. Řada softwarových firem pro specifikaci, návrh, vývoj a implementaci nových produktů využíá svých vnitřních kapacit, ale vyhledává externí služby v oblasti strategie, financí a právních služeb. Spolupráce s externími poskytovateli služeb může přinést do firmy nový pohled a užitečné podněty zvenčí. Takto získané zkušenosti pak může firma využít k dalšímu rozvoji svých vlastních kompetencí, svého růstu a konkurenceschopnosti. Velkou přidanou hodnotu mohou vytvářet služby poskytované po dodání projektového produktu (údržba, upgrady apod.), v úvahu přichází i vzdálená preventivní diagnostika.

\section{Služby v turistice a průmyslu volného času}

Turistika a průmysl volného času mají hodně společných rysů, které ovlivňují to, jak poskytují a využívají znalostně náročné služby. Rozvoj obou těchto odvětví byl vyvolán bohatnutím společnosti, vyšší vzdělaností a růstem volného času. Obě tato odvětví silně závisí na preferencích klientů. Provedené studie ukazují, že firmy v těchto sektorech mají podobné důvody k využití externích znalostních služeb: mohou od nich získat kompetence, které samy nemají, ale i nezávislá hodnocení, certifikace a pojištění.

Turistika podléhá módním vlivům a má sezónní charakter. Je ovlivněna technologickými změnami, ale na druhé straně je dost konzervativních klientů, kteří nemají rádi velké změny $v$ destinacích, do kterých se vracejí. Pro hodně turistů je cestování způsobem trávení volného času a relaxací. Klienti často kupují balíčky dodatečných služeb a spoléhají se na funkční a kvalitní infrastrukturu - dopravu, ubytování, průvodcovské služby. Roste poptávka po „adrenalinových“ zážitcích včetně různých specializovaných služeb a kurzů.

Důležitá je role mezičlánků a propojování firem se společnými zájmy. Mezičlánky pomáhají budovat a rozvíjet sítě, které jsou důležitými zdroji informací, reprezentují zájmy poskytovatelů ve vztahu $k$ veřejnému sektoru a dodavatelům.

Průmysl volného času ve velké míre závisí na rozvoji technologií a často se do velké míry spoléhá na podněty $\mathrm{k}$ inovacím vycházejícím od uživatelů (paragliding, zorbování, potápění a podobné aktivity byly vymyšleny nadšenci, teprve později byly absorbovány firmami). Mezi nejdůležitější zdroje inovací patří nadšenci, kteří čekají na nové atraktivní zážitky. Pokud jde o externí dodavatele služeb, často je využívají jako zdroje specializovaných znalostí (design, materiály, technologie apod.), pro reklamu a průzkum trhu. Často není vývoj úplně plynulý, dochází ke skokům vyvolaným dostupnými možnostmi a měnícími se požadavky zákazníků.

Pro obě tato odvětví je charakteristická flexibilita, zaměstnanost závisí na sezónnosti a často působí v mezinárodním prostředí. 


\section{Služby v dalších odvětvích}

\section{- Zdravotnictví}

Potenciál je zde velký - mnohé zdravotnické služby jsou dnes poskytovány soukromými provozovateli, kteří mají charakter MSP (od praktiků přes zubaře až po vysoce specializované a náročné výkony - dialýza, oční operace apod.).

\section{- Vzdělávání}

I zde, podobně jako ve zdravotnictví, podniká spousta vzdělávacích agentur nabízejících kurzy jak pro jednotlivce, tak pro firmy. Lze očekávat, že zájem o tyto služby poroste.

\section{- Poradenství}

Právní, účetní a auditorské služby, stejně jako služby pro průmysl, jsou typické služby založené na znalostech. Mnohé $v$ nich se vyskytující rutinní činnosti mohou být ovlivněny nástupem nových technologií, Ize předpokládat rostoucí podíl umělé inteligence, již dnes používají např. expertní systémy.

\section{Gig ekonomika}

Lze očekávat, že stávající koncept zaměstnanosti dozná v souvislosti s Průmyslem 4.0 významných změn. Dnes převažující způsob zaměstnání - hlavní pracovní poměr - bude ustupovat tomu, že si společnosti místo pracovníků pracujících na plný úvazek budou protermínované úkoly najímat nezávislé dodavatele a externí pracovníky. Pro tento způsob práce se vžil název gig ekonomika (gig je anglický termín používaný pro lehké a pohyblivé vozíky, lod'ky apod.), obecně přijatý český výraz se zatím neujal, asi nejblí̌e k němu má pojem sdílená ekonomika, ale nejde o přesný ekvivalent (Woodcock \& Graham, 2020).

Lze předpokládat, že se tento způsob práce uplatní především ve službách. Už dnes se ve firmách outsourcuje řada běžných služeb jako jsou daňové či auditorské služby, úklid, stravování, ale i údržba strojů, grafické práce a správa webu či sociálních sítí. Tyto služby jsou poskytovány bud' na smluvním základě, nebo $v$ rámci dohod o provedení práce. Výhodou pro firmy je zejména to, že nemusí kmenově zaměstnávat člověka v profesi, kterou nemohou plně využít. Pro pracující přináší tento způsob práce výhody jako je osobní svoboda, flexibilita, možnost volby pracovat jen na projektech, které je zajímají, ale i nevýhody - takový člověk má podstatně nižší pracovněprávní ochranu než řadový zaměstnanec chráněný např. zákoníkem práce, a musí se sám postarat o platby sociálního a zdravotního pojištění a další administrativní úkony. Takový člověk, který je vlastně podnikatelem, bude muset přijmout zvýšení individuální zodpovědnosti za vlastní budoucnost.

Pro rozšíření této formy práce bude nutné přijmout i určitá legislativní opatření. Stávající zákoník práce dostatečně nereflektuje ekonomické, technologické ani společenské změny. Problémem může být i legislativní opatření ukládající zaměstnavatelům povinnost evidence pracovní doby.

\section{Cirkulární ekonomika}

Cirkulární ekonomika je koncept, který je integrální součástí udržitelného rozvoje. Zabývá se způsoby, jak zvyšovat kvalitu životního prostředí a lidského života, např. pomocí zvyšování obnovitelnosti produkce. Je jedním z prioritních témat Evropské unie. Přináší příležitost materiálové soběstačnosti, vytvárí nová pracovní místa a otevírá prostor pro investice do udržitelných inovací. Pro většinu českých firem se však stále jedná o nový pojem.

Základem tohoto přístupu je inspirace prírodou, v níž odpad v podstatě neexistuje. Základem je tedy změna odpadů v suroviny vycházející z toho, že komponenty produktu jsou navrženy tak, aby mohly cirkulovat, aby je bylo možné rozložit na suroviny a znovu použít. Látky biologického původu nejsou toxické, a mohou proto být kompostovány. Syntetické látky jsou vyvinuty tak, aby mohly být užity opětovně při spotřebě minimálního množství energie. 
Koncept cirkulární ekonomiky znamená, že se musíme - na rozdíl od současné praxe rychlé obměny výrobků za nové - soustředit na výrobu produktů s delší životností, které bude možné snadno modifikovat a opravit. Nezbytností je schopnost uvažovat $v$ dlouhodobém horizontu a být schopni dávat různé jevy do souvislosti. Společnost se musí rozvíjet nejen sohledem na ekonomickou stránku, ale také brát ohled na kvalitu života a environmentální ochranu.

Design výrobku v zeleném produkčním řetězci (viz Obr. 13) by měl zohledňovat environmentální šetrnost, možnost rozebrání na jednotlivé materiály a zdravotní nezávadnost prvotního produktu. Jednotlivé součástky musí být možné snadno přeměnit zpět na zdrojovou surovinu, z níž lze vyrobit výrobek o srovnatelné kvalitě, jako byl ten původní.

\section{Obr. 13: Zelený produkční řetězec}

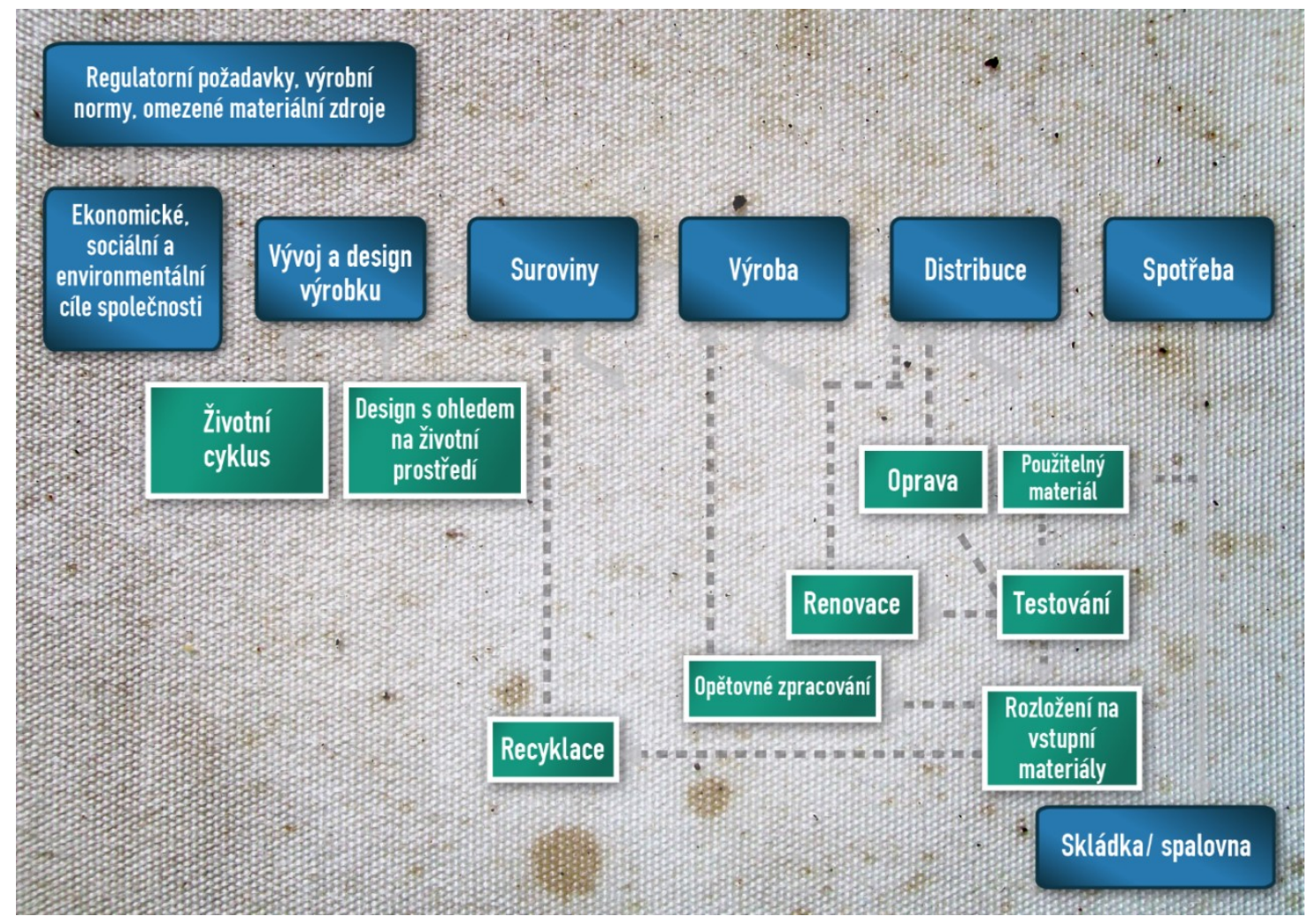

Zdroj: Wikipedia, 2020b

Koncepce cirkulární ekonomiky pomalu proniká i do České republiky. Začátkem roku 2015 vznikl Institut Cirkulární Ekonomiky, z. ú. (Institut cirkulární ekonomiky, 2018a). Institut publikoval studii Cirkulární Česko, která obsahuje i příklady úspěšných českých projektů v této oblasti (Institut cirkulární ekonomiky, 2018b) a na jeho webu Ize najít řadu publikací uvádějících příklady dobré praxe, např. Cirkulární móda, Cirkulární kavárny a podobné, které se mohou stát inspirací pro české podnikatele. Studie zároveň analyzuje i základní bariéry úspěšného fungování cirkulární ekonomiky v ČR. Za základní bariéry se považují tržní a kulturní překážky. Pro mnohé trhy jsou totiž systémy uzavřeného cyklu živin a materiálu zcela novým paradigmatem.

\section{C.2.18 Co dělat?}

Monitorujte, jak postupuje výzkum a vývoj, s čím přichází konkurence, stávajíci i potenciální partneři, jaké jsou strategické dokumenty na regionální, národní i nadnárodní úrovni. Považujte změny za príležitost, zamyslete se nad tím, jaké přiležitosti - ale i hrozby - vašemu podniku nastupující technologie přinášejí. 
Pokud jste identifikovali př́ležitost, posudte její náklady a rizika. Pokud jsou očekávané př́nosy vyšší než náklady a rizika jsou přijatelná, vypracujte inovační projekt a pust́te se do jeho realizace. Bud'te připraveni na překážky a změny, které budete muset provést. A vždy myslete na budoucí uživatele výstupů vašich inovačních aktivit. Počítejte i s tím, že se něco nepodaří - nenechte se odradit, i z neúspěchu se můžete mnohé naučit a přiště to dopadne lépe.

A nezapomeňte - jedním $z$ predpokladů úspěchu je př́stup $k$ informacím a znalostem, které jsou většinou publikovány $v$ angličtině. $V$ češtině najdete pouze málo publikací spojených $s$ tématy této kapitoly, často přicházejí se zpožděním. I v této kapitole je řada odkazů na dokumenty $v$ angličtině. Věnujte tedy pozornost zvyšování jazykových kompetencí, jazyky mají oproti technologiím jednu velkou výhodu: nemění se s exponenciální rychlostí.

\section{C.3 OPATŘENÍ PRO OBLAST ZAMĚSTNANOSTI}

Mnoho odborných studií se v souvislosti s Průmyslem 4.0 a Společností 4.0 zabývá změnami, které tyto koncepty přinesou na trh práce. Internetový portál Odbory.info (2017) upozorňují na studii Chmelař a kol. (2015), kde autoři uvádějí, že v období následujících patnácti let budou důsledky digitalizace nejvíce zasaženi techničtí a odborní pracovníci (ISCO-3), jejichž počet se významně sniží. Významné změny v souvislosti s vývojem podmínek Společnosti 4.0 lze očekávat i v sektoru znalostně náročných služeb, přičemž velmi důležitou roli budou hrát činnosti v oblasti ICT, zejména NACE 62 činnosti v oblasti informačních technologií a NACE 63 - informační činnosti. Další, silnou roli budou hrát činnosti spojené a výzkumem a vývojem (NACE 72).

V podmínkách České republiky se zaměstnanost drží na evropském průměru, z pohledu dynamiky se však Česká republika zařazuje mezi nejrychleji rostoucí země. Zde je však nutné zmínit, že růst je způsoben outsourcingem nižších a středně kvalifikačně náročných ICT činností, avšak činnosti náročnější (vývoj aplikací, informačních, kybernetických a automatizačních systémů) v mnoha případech zůstávají v mateřských společnostech a jejich centrálách (MPO, 2015). Každopádně pro aplikaci a rozvoj konceptu Průmyslu 4.0 je podstatný rozvoj služeb náročných na znalosti, z nich pak především služeb technologicky náročných, a to zejména již výše jmenované oblasti NACE 62,63 a 72. Deloitte (2018) ve své studii poukazuje na fakt, že automatizace proniká i do oblasti vývoje software, kdy umělá inteligence akceleruje k vývoji v dané oblasti.

Na trhu práce bude sílit poptávka po uchazečích s komplexnějšími znalostmi a dovednostmi, schopností uvažovat v širších souvislostech a ochotou k neustálému vzdělávání, přičemž zásadní důraz se bude klást na digitální gramotnost, T-shaped professional, neboli profesionální znalosti ve tvaru T, tzn. současně hluboké a široké znalosti, a neustálý nárůst měkkých dovedností (Kohout, Palíšková, 2017).

Koncepce Průmyslu 4.0 a Společnosti 4.0 s sebou tedy přináší zásadní změny v oblasti pracovních míst na úrovni podniků. Trendy spojené s uvedenými koncepty Ize shrnout do těchto základních okruhů (MPSV, 2016):

- zkrácené pracovní úvazky,

- využívání online platforem,

- trvalé pracovní úvazky,

- flexibilní typy práce - gig ekonomika, kurzarbeit,

- soulad rodinného a pracovního života - práce z domova a vytvoření podmínek pro tento typ práce,

- časová a finanční dostupnost předškolní vzdělávací péče,

- větší zapojování osob se zdravotním postižením,

- digitální gramotnost,

- výukové materiály a nabídka vzdělávacích činností pro lepší adaptaci na trhu práce. 
V návaznosti na výše uvedené a s ohledem na výstupy získané v rámci realizace projektu z řízených rozhovorů s důrazem na znalostně náročné služby na úrovni malých a středních podniků Ize shrnout opatření, která by měly podniky realizovat s ohledem na zaměstnanost, následovně:

1. potřeba větší kvalifikace personálu,

2. nutnost vzdělávání zaměstnanců v kontextu principů Průmyslu 4.0 a Společnosti 4.0,

3. podpora outsourcingu v oblastech podpůrných procesů podniku,

4. provádění automatizace rutinních procesů.

Text níze uvádí podrobnosti $k$ jednotlivým navrženým opatřením s přihlédnutím na získané poznatky z rízených hovorů. Pro rekapitulaci, v roce 2019 bylo realizováno celkem 20 řízených hovorů se subjekty ze sektoru malých a středních podniků působících v oblasti znalostně náročných služeb (sekce NACE J a M).

\section{Opatření 1. (potřeba větší kvalifikace personálu) a 2. (nutnost vzdělávání zaměstnanců v kontextu principů Průmyslu 4.0 a Společnosti 4)}

Tato opatření spolu úzce souvisí. Kvalifikace personálu se logicky odvijí od konkrétního odvětví působení podniku v sektoru znalostně náročných služeb. Kromě nutnosti zvyšovat kvalifikaci v oblasti digitálních a informačních technologií (viz text dále), je zřejmé, že zrovna tyto zkoumané sektory potřebují do velké míry zaměstnance oplývající schopností kreativity, kritického a systémového myšlení, inovace a schopnosti spolupráce. Především schopnost kritického a systémového myšlení byla vyzdvihována $v$ rámci řízených rozhovorů. Dále pracovní místa jsou stále více zaměřena na řešení strukturovaných problémů a efektivní analýzu informací a je tedy nutné podporovat zaměstnance $\checkmark$ rozvíjení jejich schopností analytického myšlení, čtenářské, numerické a ICT gramotnosti, ve schopnosti leadershipu, zvyšování kvalifikace voblasti vyhodnocování a evaluace komplexních informací, koučování či i v emoční inteligenci (WEF, 2018).

Jak již bylo zmíněno, je více než jasné, že velká míra požadavků kladených na vyšší kvalifikaci zaměstnanců bude navázána na oblast vzdělávání v digitálních a informačních technologiích. Tento fakt podporuje i Kruliš (2018), který zdůrazňuje nutnost zlepšení technického vzdělávání již na základních a středních školách, tedy nejen na úrovni vysokoškolského vzdělání. Zároveň, jak zdůrazňuje Světové ekonomické fórum (WEF, 2018), více jak dvě třetiny dětí, které dnes vstupují do základních škol, budou vykonávat zaměstnání, která $v$ současné době ještě neexistují. $S$ touto skutečností musí podniky do jisté míry počítat, jinak jim do budoucna může působit značné problémy, pokud již ted' nebudou předpokládat změnu požadavků a postupně se nebudou snažit aplikovat je v podobě celoživotního procesu zvyšování kvalifikace. Tudíz apel na digitální gramotnost zaměstnanců Ize jednoznačně doporučit. Nutno podotknout, že v sektoru znalostně náročných služeb jde o jednoznačný předpoklad udržení konkurenceschopnosti podniku.

Na potřebu větší kvalifikace zaměstnanců navazuje plynule i další navržené opatření, a to nutnost dalšího vzdělávání zaměstnanců v kontextu principů Průmyslu 4.0 a Společnosti 4.0 . Zde je opět potřeba podporovat vzdělávání zaměstnanců zejména vIT dovednostech (viz text výše), dále podporovat využití online komunikačních kanálů, webinářů apod. (přičemž i v souvislosti s epidemií COVID-19 se ukázalo uvedené jako velmi dobře využitelné a zároveň nutné).

V kostce shrnuto, podniky musí nutně podporovat zvyšování kvalifikace zaměstnanců směrem ke klíčovým dovednostem a schopnostem (systematické/kreativní myšlení, kreativita, rozvíjení inovačního potenciálu, schopnosti analytického myšlení, leadershipu a zhodnocení komplexních informací), stejně tak jako vzdělávání v návaznosti na principy Průmyslu 4.0. a Společnosti 4.0. Tato opatření by neměla být realizována v hromadné podobě, ale na individuální úrovni dle konkrétních potřeb kladených na zaměstnanecké pozice. Významná je vnitřní motivace zaměstnanců, a to jak prostřednictvím finančních, tak nefinančních benefitů (které opět mohou být spojené se změnami v oblasti pracovních míst - např. motivace v podobě možnosti práce z domova aj.). Podstatná je také 
existence průběžně aktualizovaného plánu vzdělávání a zvyšování kvalifikace zaměstnanců s možností získání zpětné vazby na takto realizovaná opatření. Velká část těchto aktivit má, dle výstupů z řizených rozhovorů, logickou návaznost na opatření 3. a 4. - tj. schopnost využívat potenciál outsourcovaných podpůrných procesů a zautomatizovaných procesů (napríklad schopnosti využít potenciál ERP, CRM systémů). Opatření $v$ této oblasti by měla být tedy navázána na identifikování základních potřeb kvalifikace a vzdělávání zaměstnanců v kontextu Průmyslu 4.0 a Společnosti 4.0 - viz uvedeno výše - a současně individuálních potřeb odvíjejících se od konkrétní pracovní pozice. Následně realizovaná opatření by měla být průběžně hodnocena a aktualizována dle vývoje dalších požadavků na pracovní pozici.

Opatření 3. (podpora outsourcingu v oblastech podpůrných procesů podniku) a opatření 4. (provádění automatizace rutinních procesů)

$K$ dalším navrženým opatřením, tj. podpora outsourcingu $v$ oblastech podpůrných procesů podniku a provádění automatizace rutinních procesů, Ize zkonstatovat, že dle provedených ř́zených rozhovorů podniky $v$ sektoru znalostně náročných služeb shledávají jako vhodný outsourcing podpůrných procesů, stejně tak již v současné době mají řadu rutinních procesů plně automatizovaných. Tento trend Ize tedy jednoznačně doporučit $k$ aplikaci ve větší míre. Outsourcing je realizován především v oblasti IT řešení, často z důvodu nedostatku vhodných pracovníků, znalostí či času potřebného $\mathrm{k}$ dosažení požadovaného výstupu.

Lze hovořit především o využití outsourcingu v oblasti ERP, CRM systémů, cloudových řešení, což umožní současně i automatizaci řady rutinních procesů (např́klad v oblasti administrativy, účetnictví, řízení lidských zdrojů). Všechna tato opatření realizují podniky často s vidinou zkvalitnění kontaktu se zákazníky a limity těchto opatření Ize spatřovat v rovině finanční, nedostatečných schopností pracovat $s$ takto nadesignovaným řešením a obavou z přilišné komplexnosti daného řešení. Tato opatření určují ovšem nezbytný trend budoucnosti a především podniky voblasti znalostně náročných služeb by je měly $v$ dostatečné míře využívat a rozvíjet. Speciální kapitolou jsou podniky aktivní v IT sféře, které často implementují vlastní IT řešení umožňující automatizaci rutinních, interních procesů, např́iklad s využitím robotické automatizace procesů (Deloitte, 2017b).

Velmi vhodné je využívání dálkového přístupu (opět je třeba připomenout hojné využívání v souvislosti spandemií COVID-19), a to například na úrovni zpracování účetnictví a přenosu k uživatelům (manažerům, analytikům, burzovním makléřům, případně dalším uživatelům účetních informací) a využivání datových center (Portál Pohoda, 2014). Zde Ize dále navázat na doporučení MPSV (2016), kdy dálkový přístup umožňuje zavedení flexibilních pracovních podmínek, možnost využívat zkrácené pracovní úvazky (pro matky na mateřské dovolené, zdravotně handicapované) a práce $z$ domova.

Opatření je potřeba zavádět a realizovat sohledem na individuální požadavky podniku, s respektováním jeho konkrétní podnikatelské činnosti, personální politiky, nastavení podnikových procesů apod.

Podnikům by mohl napomoci niže uvedený check-list (Tab. 8), aby si učinily určité sebehodnocení z hlediska využívání konkrétních nástrojů pro zlepšování v oblasti práce s lidskými zdroji v kontextu Společnosti 4.0, samozřejmě při respektování jejich individuálních potřeb. 
Tab. 8: Check-list pro podniky - souhrn opatření v oblasti zaměstnanosti v konceptu Společnosti 4.0

\begin{tabular}{|c|c|c|}
\hline Číslo a popis opatření & Specifikace opatření v zaměstnání & Podnik využívá \\
\hline $\begin{array}{l}\text { Opatření } 1 . \\
\text { (potřeba větší kvalifikace personálu) } \\
\text { a opatření } 2 \text {. } \\
\text { (nutnost vzdělávání zaměstnanců } \\
\text { v kontextu principů Průmyslu } 4.0 \\
\text { a Společnosti 4) }\end{array}$ & $\begin{array}{l}\text { - } \quad \text { IT znalosti a dovednosti } \\
\text { - } \quad \text { digitální gramotnost } \\
\text { - } \quad \text { kreativní myšlení } \\
\text { - } \quad \text { kritické a systémové myšlení } \\
\text { - } \quad \text { analytické myšlení } \\
\text { - } \quad \text { inovativní přístup } \\
\text { - } \quad \text { týmová práce } \\
\text { - další vzdělávání (školení, webináře apod.) }\end{array}$ & $\begin{array}{l}\text { ANO - NE } \\
\text { ANO - NE } \\
\text { ANO - NE } \\
\text { ANO - NE } \\
\text { ANO - NE } \\
\text { ANO - NE } \\
\text { ANO - NE } \\
\text { ANO - NE }\end{array}$ \\
\hline $\begin{array}{l}\text { Opatření } 3 \text {. } \\
\text { (podpora outsourcingu v oblastech } \\
\text { podpůrných procesů podniku) }\end{array}$ & $\begin{array}{ll}\text { - } & \text { outsourcing } v \text { oblasti IT řešení } \\
\text { - } & \text { outsourcing v oblasti ERP } \\
\text { - } & \text { outsourcing v oblasti CRM } \\
\text { - } & \text { outsourcing PR } \\
\text { - } & \text { outsourcing marketingu administrativních procesů } \\
\text { - } & \text { outsourcing účetních procesů } \\
\text { - } & \text { outsourcing v oblasti řízení lidských zdrojů }\end{array}$ & $\begin{array}{l}\text { ANO - NE } \\
\text { ANO - NE } \\
\text { ANO - NE } \\
\text { ANO - NE } \\
\text { ANO - NE } \\
\text { ANO - NE } \\
\text { ANO - NE } \\
\text { ANO - NE }\end{array}$ \\
\hline $\begin{array}{l}\text { Opatření } 4 . \\
\text { (provádění automatizace rutinních } \\
\text { procesů) }\end{array}$ & $\begin{array}{l}\text { - } \quad \text { automatizace v oblasti vedení účetnictví } \\
\text { - } \quad \text { automatizace v oblasti výběru } \\
\text { - } \quad \begin{array}{l}\text { automěstnanců } \\
\text { procesů }\end{array} \\
\text { - } \quad \begin{array}{l}\text { automatizace } v \text { oblasti administrativních } \\
\text { aplikacích }\end{array}\end{array}$ & $\begin{array}{l}\text { ANO - NE } \\
\text { ANO - NE } \\
\text { ANO - NE } \\
\text { ANO - NE }\end{array}$ \\
\hline
\end{tabular}

Zdroj: vlastní zpracování, 2020

\section{C.4 OPATŘENÍ PRO OBLAST PŘÍSTUPU KE ZDROJŮM}

Výše uvedené subkapitoly nabádají k adaptaci podniků na principy Společnosti 4.0 a mají pomoci připravit se na potenciální rizika a využití př́ležitostí. Tato subkapitola se bude $v$ rámci využití př́ležitostí zabývat možnými přistupy $\mathrm{k}$ finančním a znalostním zdrojům.

a) Př́stup $k$ finančním zdrojům

Za účelem financování investic, resp. změn souvisejících s adaptací podniku na Společnost 4.0 může podnik využívat jednak zdrojů vlastních (zvýšení ochoty $k$ uvolnění vlastních zdrojů za účelem zabezpečení vzdálených přistupů a dalších forem digitalizace je zřetelné u mnoha společností $v$ době koronavirové pandemie) nebo čerpat finanční podporu z externích zdrojů.

Finanční podpora (různých segmentů ekonomiky - včetně malých a středních podniků) je podnikům poskytována jednak návratným způsobem (poskytováním finančních nástrojů - úvěrů a záruk), nebo nenávratným způsobem (poskytováním dotací). Dotace jsou výhodné svoji intenzitou, avšak nevýhodou je vysoká finanční náročnost (z pohledu poskytovatele) a jednorázovost. Finanční nástroje mají naopak výhodu vyšší efektivity (prostředky z úvěrů po splacení může poskytovatel opakovaně použít pro hospodářskou politiku) a nevýhodou je nižší intenzita (Jirásek, 2020).

$\checkmark$ rámci využívání návratných zdrojů resp. úvěrů se může podnik potýkat s problémem stanovení optimální struktury kapitálu a dále s navazujícím problémem př́stupu k cizím zdrojům. Optimální kapitálové struktury je obecně dosaženo, pokud jsou stejné mezní náklady každého zdroje financování, přičemž neexistuje jednoznačně určitelná či všeobecně platná míra. Optimální poměr 
mezi vlastními a cizími zdroji je dán mnoha faktory interními (např. cash flow, flexibilita, růst a stabilita podniku) a externími (např. výše úrokových sazeb, daňová politika, charakter odvětví). Obecně lze však doporučit dodržování tzv. „zlatých“ pravidel:

Zlaté bilanční pravidlo financování - toto pravidlo požaduje financovat stálá aktiva z dlouhodobých zdrojů, především z vlastního kapitálu, přičemž tyto dlouhodobé zdroje by měly navíc $s$ patřičnou rezervou převyšovat stálá aktiva (dlouhodobý majetek). $V$ opačném prípadě by se jednalo o podkapitalizovaný podnik, který se vystavuje riziku vzniku platební neschopnosti vyvolávající stav existenčního ohrožení.

Zlaté bilanční poměrové pravidlo - toto pravidlo porovnává vztah dynamiky zvyšování investic a výnosů, kdy zvyšování investic by nemělo předběhnout dynamiku růstu tržeb podniku.

Zlaté pari pravidlo - toto pravidlo zaujímá vztah stálých (dlouhodobých) aktiv a vlastního kapitálu. Podle něj by stálá aktiva měla být financována hlavně z vlastních zdrojů podniku.

Zlaté pravidlo vyrovnání rizik - toto pravidlo ř́ká, že objem vlastních a cizích zdrojů by se měl rovnat. Někteří autoři však toto pravidlo vykládají tak, že by vlastní zdroje podniku měly převyšovat cizí zdroje.

Finanční podporu mohou malé a střední podniky čerpat převážně ze zdrojů uvedených v Obr. 14. Nejedná se však o úplný výčet existujících zdrojů. Namátkou lze dále jmenovat např. Rámcové programy pro výzkum a vývoj (více informací např.: Národní portál pro evropský výzkum, 2020), dále INTERREG (více na: DotaceEU.cz, 2020) apod.

Obr. 14: Možnosti finanční podpory podniků v ČR

\section{FINANČNÍ PODPORA}
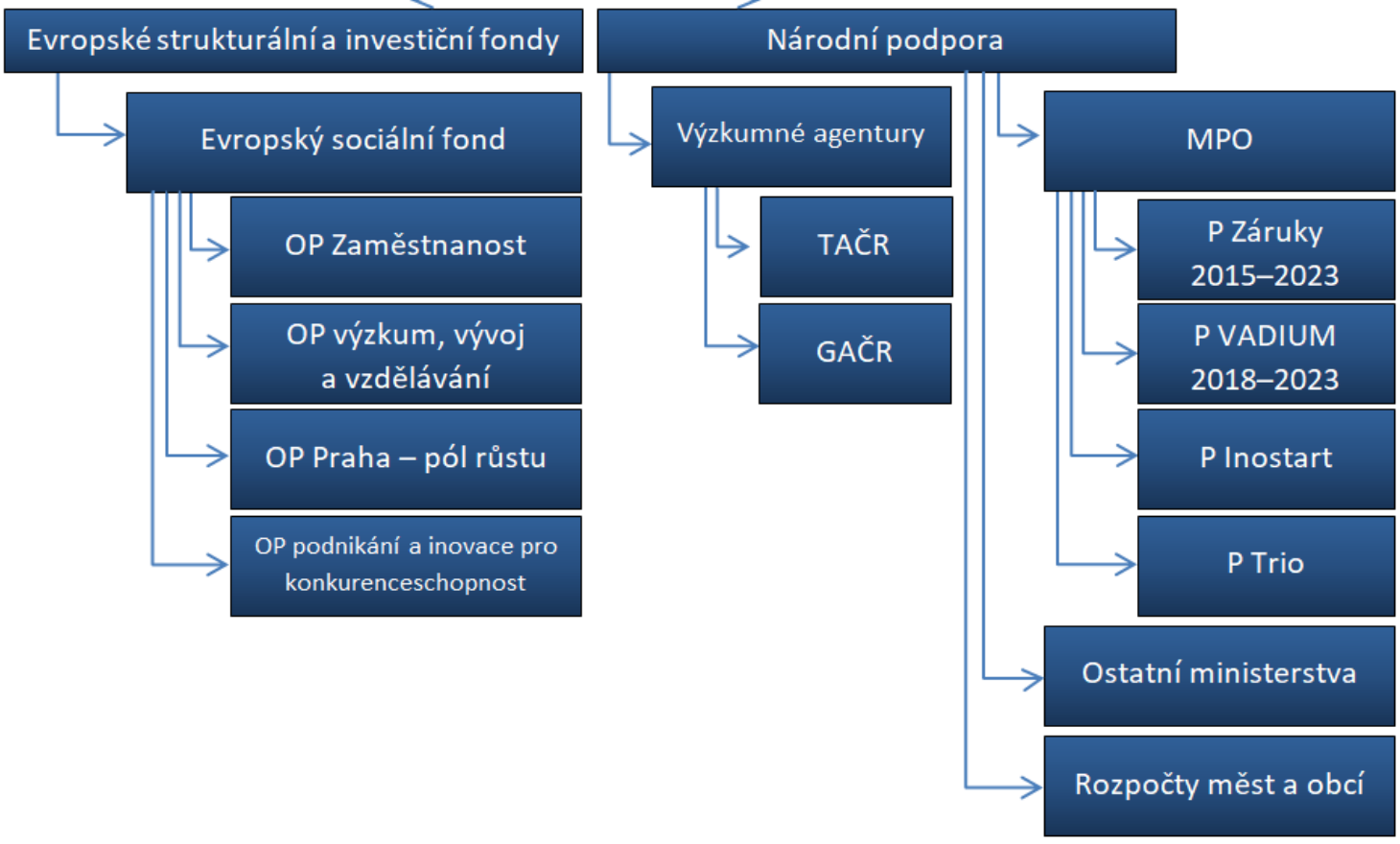

Zdroj: vlastní zpracování, 2020

V rámci Evropských strukturálních a investičních fondů je na technické řešení a podporu inovací souvisejících $s$ adaptací MSP na Společnost 4.0 určen Evropský fond pro regionální rozvoj a dále Evropský sociální fond, a to prostřednictvím těchto operačních programů: 
Operační program Zaměstnanost (ř́zený Ministerstvem práce a sociálních věcí) - v rámci něhož Ize v současnosti získat např:

- Bezúročný úvěr S-PODNIK - usnadňující sociálním podnikům financování investičních projektů zaměřených na zahájení či rozvoj podnikatelské činnosti. Projekty lze realizovat kdekoliv na území ČR včetně hlavního města Prahy (ČMZRB, 2020).

Operační program Výzkum, vývoj a vzdělávání (ř́zený Ministerstvem školství, mládeže a tělovýchovy).

Operační program Praha - pól růstu (ř́zený Magistrátem hlavního města Praha) - v rámci něhož Ize v současnosti získat např:

- Bezúročný úvěr INFIN - pro začínající podnikatele a podnikatele s historií do 7 let (tzn. pouze pro MSP i rodinné firmy) se sídlem a místem realizace na území Prahy - s možností odkladu splátek až 3,5 roku (ČMZRB, 2020).

Operační program Podnikání a inovace pro konkurenceschopnost (řízený Ministerstvem průmyslu a obchodu) - v rámci něhož lze v současnosti získat např:

- Bezúročný úvěr EXPANZE - pro malé a střední podniky na projekty investičního charakteru, např. pořízení nových strojů a zařizení, nákup technologických postupů, programů, licencí a software (ČMZRB, 2020).

Z operačního programu Podnikání a inovace pro konkurenceschopnost (OP PIK) je prostřednictvím MPO ČR poskytována také řada nenávratných finančních podpor - dotací. Dotační výzvy jsou zveřejňovány na webových stránkách Agentury pro podnikání a inovace (2020). Zajímavou přiležitostí je např. výzva o dotaci v programu Partnerství znalostního transferu, v rámci které mohou malé a střední podniky získat dotaci na několikaleté projekty, jejichž obsahem je přenos znalostí z vysoké školy či jiné výzkumné organizace. Přenesené znalosti podniky využijí pro zlepšení svých procesů nebo pro inovaci svých výrobků a služeb, včetně designu. Tento projekt je založen na práci absolventa (max. 6 let po ukončení studia), který je po celou dobu realizace zaměstnán univerzitou a v roli tzv. asistenta znalostního transferu adaptuje akademické znalosti na praktické potřeby podniku. Ten mu k tomu účelu ve svých prostorách vybaví specializované pracoviště (bic.cz, 2020).

V roce 2020 jsou diskuze o programovém období 2021+ v plném proudu a Česká republika $\checkmark$ nich na národní i mezinárodní úrovni hraje aktivní roli. Pro členské státy je nutností se vyrovnat s řadou nových výzev, které jednotlivé státy a i EU jako celek čekají (DotaceEU.cz, 2020). Pozice ČR je $\checkmark$ této době definována $v$ řadě strategických dokumentů vznikajících ve spolupráci $s$ odbornou veřejností, proto Ize očekávat, že i pro programové období 2021-2027 bude možnost aktivně využívat finančních podpor obdobných těm výše uvedeným.

Národní podpora je realizována v prvé řadě na úrovni výzkumu a inovací prostřednictvím Grantové agentury ČR a Technologické agentury ČR. Druhá ze zmíněných agentur podporuje symbiózu výzkumných institucí a podniků prostřednictvím financování výzkumných projektů. $V$ souladu s tématem tohoto katalogu jsou vypisovány zejména tyto programy (TAČR, 2020):

- Program Éta - podporuje aplikovaný společenskovědní a humanitní výzkum, experimentální vývoj a inovace,

- Program Trend - podporuje výsledky s potenciálem pro konkurenceschopnost - nové produkty, výrobní postupy a služby,

- Program Epsilon - podporuje projekty zaměřené převážně na průmyslové technologie, jejichž výsledky mají rychlé uplatnění na trhu,

- $\quad$ Program Prostředí pro život - podporuje výsledky s vlivem na zdravé a kvalitní životní prostředí a udržitelnost využívání prírodních zdrojů. 
V rámci národní podpory je poskytována finanční podpora např. prostřednictvím následujících programů Ministerstva průmyslu a obchodu (MPO):

- Program ZÁRUKY 2015 až 2023 - cílem je podpořit prostřednictvím záruk přístup malých a středních podnikatelů $\mathrm{k}$ bankovním úvěrům na realizaci jejich podnikatelských projektů. $\checkmark$ rámci tohoto programu budou podnikatelům poskytovány záruky až do $80 \%$ jistiny zaručovaného úvěru, jehož výše může činit až 30 mil. Kč, sociálním podnikatelům budou poskytovány i finanční príspěvky až do výše 10 \% zaručovaného úvěru, ne však více než 500000 Kč (MPO, 2020a).

- Program VADIUM 2018-2023 - cílem programu je podpořit prostřednictvím záruk přistup malých a středních podnikatelů $\mathrm{k}$ zakázkám $\mathrm{z}$ výběrových/zadávacích řízení. $\mathrm{V}$ rámci tohoto programu budou podnikatelům poskytovány záruky, které budou sloužit jako jistota $v$ prípadě výběrového/zadávacího řízení vyhlášeného subjektem se sídlem na území České republiky, jehož předmětem je dodávka zboží, služeb nebo stavebních prací (MPO, 2020b).

- Program INOSTART, který nabízí úvěry a zvýhodněné záruky za úvěry začínajícím podnikatelům z celé České republiky. Úvěry z programu INOSTART od 500 tisíc do 15 milionů Kč Ize využít na financování nákupu hmotného, nehmotného, investičního a neinvestičního majetku i na pokrytí provozních nákladů. Financování poskytuje Česká spořitelna a záruky za ně vystavuje Českomoravská záruční a rozvojová banka. Bankovní záruky za úvěry v rámci programu INOSTART se navyšují o 10 \% a mohou tak zajištóvat až 70 \% jistiny úvěru (MPO, 2020c).

- Program Trio - posláním je podpořit aktivity v průmyslovém výzkumu a experimentálním vývoji, které budou využívat a dále rozvíjet potenciál v oblasti klíčových technologií (MPO, 2020d).

$\checkmark$ rámci finanční podpory je možné podnikům také navrhnout využití nových balíčků služeb pro digitalizaci, které jsou nabízeny prostřednictvím výzvy MPO a měly by se týkat napríklad hlasových a datových služeb, zabezpečení datových přenosů, pořízení hardware, marketingu, on-line prodeje, inovativního způsobu prodeje, IT podpory a/nebo vzdáleného prístupu do firmy apod. To vše $s$ cílem usnadnit malým podnikům a živnostníkům podnikání a fungování v on-line světě (MPO, 2020e).

Na národní úrovni mohou být také malým a středním podnikům poskytovány finanční podpory z rozpočtů měst a obcí. Příkladem mohou být tzv. „mikrogranty“, které slouží pro zajištění údržby, ale i investice $v$ nemovitostech ve vlastnictví žadatele. Maximální požadovaná částka se pohybuje kolem 20000 Kč/žádost (MÚ Plzeň-Doubravka, 2020).

b) Př́stup ke zdrojům v oblasti znalostního vybavení

Adaptace podniků na principy Společnosti 4.0 není možná bez odpovídajícím způsobem kvalifikované pracovní síly. Tu Ize zajistit jednak náborem nových zaměstnanců, nebo proškolením těch stávajících. Dle MPO (2020f) Ize rozhodující prínos zejména k technologickému rozvoji očekávat zejména od pracovní síly s terciárním vzděláním technického směru, i když je zastoupení osob s ostatními obory vzdělání (zejména prírodovědnými a manažerskými) neméně důležité. Se zprostředkováním nové pracovní síly pomáhají úřady práce, které na jednotlivých kontaktních pracovištích administrují agendu poptávaných profesí od podniků a aktivně pomáhají střetu s nabídkou.

Pro podporu uspokojení poptávky podniku po kvalifikované pracovní síle je podnikům možné navrhnout opatření spolupráce $s$ odbornými školami, at' již na úrovni sekundárního vzdělávání (odborné školy) nebo terciárního vzdělávání (univerzity). Tato spolupráce může mít podobu odborných seminářủ (na půdě školy či podniku), exkurzí, odborných praxí či výcviků, zadávání úkolů nebo zadávání a participace na vypracování kvalifikačních prací ( $v$ rámci terciárního vzdělání bakalářských/diplomových prací). Na mnoha středních i vysokých školách je zřetelná spolupráce s podniky díky demonstračním materiálům ve veřejných prostorech školy (např. informační letáky 
na nástěnkách, demonstrační skříňky $s$ výrobky). Spolupráce by neměla probíhat pouze na úrovni podnik - student, ale mělo by dojít také k angažování managementu školy a učitelů, kteří prostřednictvím této spolupráce získají důkazy, resp. zpětnou vazbu ke znalostem a dovednostem, které podniky požadují po absolventech.

Zajímavou př́ležitostí k navázání kontaktu podniků se studenty je účast na Veletrhu pracovních př́ležitostí, který každoročně ( $v$ roce 2020 již po dvacáté páté) pořádá Západočeská univerzita v Plzni. Jedná se o plošně největší veletrh v západních Čechách, který podnikům přináší unikátní př́ležitost oslovit desítky studentů a absolventů z širokého spektra oborů. Podniky zde mají možnost realizovat přednášky pro studenty, přičemž organizátoři akce mohou zástupcům praxe poradit, jak studenty zaujmout nebo jak propagovat svůj brand (ZČU, 2020).

V rámci proškolování stávajících zaměstnanců Ize navrhnout opatření, jak podporovat angažovanost podniků ke vzdělávání zaměstnanců, a to efektivním způsobem, tzn. tak, aby byli školení zaměstnanci přesvědčeni o pozitivních př́nosech pro výkon své práce. Způsoby dalšího vzdělávání zaměstnanců mohou být zaměřené koncepčně na dlouhodobý rozvoj (např. podpora vyššího vzdělání zaměstnanců, podpora studia př́slušného oboru na příslušném stupni vzdělání) nebo se může jednat o krátkodobé kurzy (semináře, workshopy). $V$ rámci tématu této subkapitoly byl proveden průzkum trhu $s$ nabízenými krátkodobými kurzy (semináŕi) zaměřenými na oblast digitalizace firemních procesů. Výsledky tohoto průzkumu (včetně průměrné finanční náročnosti na účastníka kurzu) jsou uvedeny v príloze č. 3.

\section{C.5 OSTATNÍ OPATŘENÍ}

Přístup k financování má pro malé a střední podniky zásadní význam z hlediska jejich růstu a inovací. Podle průzkumu provedeného $v$ celé EU (zveřejněného $v$ roce 2016) je přístup $k$ financování nejdůležitějším problémem pro 9 \% malých a středních podniků v EU (European Commission, 2020). Za účelem financování:

- počátečního stádia podnikání,

- vývoje nové služby,

- rozvoje služby (včetně marketingu) a

- růstu resp. urychlení rozvoje podniku

Ize využít služeb business anděla (Angel Investor). Jedná se o osobu či subjekt, který na základě svého rozhodnutí poskytne chybějící kapitál do vybraného projektu či podniku, ve kterém shledává růstový potenciál. Tento investor však nepřispívá pouze po finanční stránce, nýbrž poskytuje i své zkušenosti, které mohou být zejména v raném stádiu podnikání stěžejní. Portál Hyperfinance. cz (2020) uvádí, že business andělé očekávají velkou návratnost vloženého kapitálu, která se většinou pohybuje kolem 20 až $30 \%$.

Specifickým řešením financování (důležitým zejména pro projekty a společnosti spojené s vyšším rizikem a inovacemi) je rizikový kapitál (venture kapital). Činnosti v oblasti rizikového kapitálu jsou nejrozsáhlejší na nejrozvinutějších kapitálových trzích (např. ve velkých zemích EU, Beneluxu, severských zemích). Rizikový kapitál je lépe uzpůsoben potřebám začínajících a rizikovějších podniků, avšak představuje jen malý zlomek soukromého kapitálu. K hlavním institucionálním investorům do fondů rizikového kapitálu patř́ pojišt́ovny a penzijní fondy (European Commission, 2020). V České republice působí asociace CVCA, která zastupuje zájmy společností působících v oblasti private equity a venture kapitálu v ČR. Členy asociace je naprostá většina fondů private equity a venture kapitálu působících $v$ ČR a dále jsou členy této asociace také společnosti, které $v$ oblasti private equity a venture kapitálu poskytují poradenské služby, a také banky a pojištónny (CVCA.cz, 2020). 
Opatřením pro zavedené firmy, které nemají problém s rozpočtem, ale nechtějí jím plýtvat vyvíjením nové služby, o kterou nemusí být zájem, může být využití tzv. crowdfundingové kampaně. Ta spočívá ve vymezení jasného rozpočtu, který je dle portálu fundchaser.com (2020) zpravidla menší než rozpočet na vývoj nové služby, a oslovení cílové skupiny prostřednictvím crowdfundingových portálů, např:

- Kickstarter (nutnost mít partnera z USA, VB nebo Nizozemska),

- IndieGoGo (bez překážek využitelný i z ČR),

- Tilt (nutný účet v USA nebo v Kanadě),

- CircleUp,

- Crowdfunder,

- HitHit - na webových stránkách deklarovaný jako česká crowdfundingová platforma (HitHit, 2020).

Zavedené firmy si touto kampaní mohou otestovat zájem o novou službu (či produkt). Pokud je kampaň úspěšná, je to jasný impuls, že služba by se mohla realizovat. Kampaň může přilákat pozornost médií a vytvořit tedy lepší povědomí o firmě.

Mezi další způsoby financování malých a středních podniků Ize zahrnout také sekuritizaci či kótování na burze cenných papírů. Sekuritizací je nazýván proces, v rámci něhož věřitel (zejména banka) vytvoří sdružením aktiv finanční nástroj za účelem nabídky pro investory. Účelem je usnadnit přístup širšímu spektru investorů a následně tak zvýšit likviditu, resp. uvolnit kapitál bank pro další půjčky (European Commission, 2020). Pokud malý a střední podnik hledá potenciál k širší základně kapitálových investorů, je vhodným řešením možnost kotace na burze cenných papírů. Evropská komise uvádí, že pro malé a střední podniky (které nemohou či nechtějí kotovat na hlavních akciových trzích) jsou zvláště vhodné trhy s růstovými akciemi nabízející možnost kotování se zjednodušenými požadavky (European Commission, 2020).

\section{C.6 OPATŘENÍ ZAJIŠŤUJÍCÍ ZPĚTNOU VAZBU}

Metodika cílí na adaptaci MSP v sektoru znalostně náročných služeb na podmínky Společnosti 4.0. Pokud se na sektor těchto podniků podíváme komplexním pohledem, zjistíme, že více než $99 \%$ všech firem v České republice jsou právě MSP. MSP zaměstnávají celkem cca $60 \%$ všech zaměstnanců. Podíl přidané hodnoty MSP pritom činí cca $55 \%$. Sektor MSP je tak významnou hnací silou podnikatelské sféry, růstu, inovací i konkurenceschopnosti a představuje také významného zaměstnavatele. Je tak zřejmý i vliv MSP v sektoru znalostně náročných služeb na národní hospodářství. Cílem této subkapitoly je proto podpořit MSP působící v oblasti znalostně náročných služeb v zavádění nových technologií založených na Průmyslu 4.0, ukázat šance a eliminovat případná rizika spojené s jejich zaváděním a užíváním.

MSP v oblasti znalostně náročných služeb by měly v krátkodobém, střednědobém, ale i dlouhodobém horizontu měřit svou výkonnost. Podniky by měly znát svou finanční situaci. To je základním předpokladem nejen pro zavedení opatření zajištujících bezproblémovou adaptaci na podmínky Společnosti 4.0, ale i pro udržení, další inovaci a aktualizaci aktivit podniku. Výkonnost značí to, co podnik vyrábí, nebo poskytuje. Dosažení externího výkonu je vnímáno př́mo jako podstata podnikatelské činnosti (Chung, Jang a Kim, 2019). Význam hodnocení podniku roste zejména v době hospodářské krize, $v$ době, kdy se podniky ocitají ve finanční tísni a krachují. $V$ praxi mezi hodnotová kritéria k měření výkonnosti patř́ různé ukazatele, analýzy a metody.

S měřením výkonnosti prímo souvisí také životní cyklus podniku, který prezentuje pozici podniku a může firmě mnoho napovědět. Životní cyklus se rozděluje na fáze založení, růstu, stabilizace, krize a zániku (viz Obr. 15). Ideální je stav, kdy podnik neprochází všemi fázemi, nebot' cílem managementu 
je dlouhodobé fungování a vyhnutí se krizi, která může přerůst až v zánik podniku (Strouhal, 2014). Během své existence může podnik ukončit činnost ve kterémkoliv stádiu, což nebude cílem této metodiky. Metodika je zejména cílena na podniky, které se nacházejí ve stabilní fázi, prípadně fázi konstantního růstu. K udržení se $v$ těchto fázích a udržení zvyšující se hodnoty podniku v sektoru znalostně náročných služeb je nutné adaptovat se na nové podmínky, realizovat inovace, zvyšovat kvalifikaci, zvažovat nové možnosti, a to vše ve spojení s Průmyslem 4.0. Management podniků musí mnohdy přehodnotit své podnikatelské ambice a vrátit se do předchozího stádia z důvodu nezvládnutí přechodu na další úroveň, ustrnutí na starém (Veber \& Srpová, 2012). Ve fázi růstu by měl podnik mít nastaveny výsledkové parametry, vhodnou cenovou strategii (tedy náklady vs. prodejní cena), poté lze očekávat i požadovanou ziskovost. Růst může podle Strouhala (2014) vyvolat zvýšenou potřebu kapacity, na což pochopitelně navazují investice a způsoby financování (bude popsáno níže). Podnik ve fázi stability představuje předpoklad pro uspokojování potřeb vlastníků, zaměstnanců i manažerů. Právě tuto fázi musí podnik využít pro svůj budoucí růst. Důležitá je inovace systému péče o zákazníky, inovace nabízených služeb, personální politika, optimalizace rízení podniku (Belás a kol., 2014). Právě v období stabilizace podnik zjistí, že celá řada procesů se dá v podniku zautomatizovat a zjednodušit. $V$ této fázi se musí vlastník podniku rozhodnout, zda príime pozici vizionáře a soustředí se na strategické rozhodování, nebo přenechá vedení podniku kvalifikovaným pracovníkům.

\section{Obr. 15: Životní cyklus podniku}

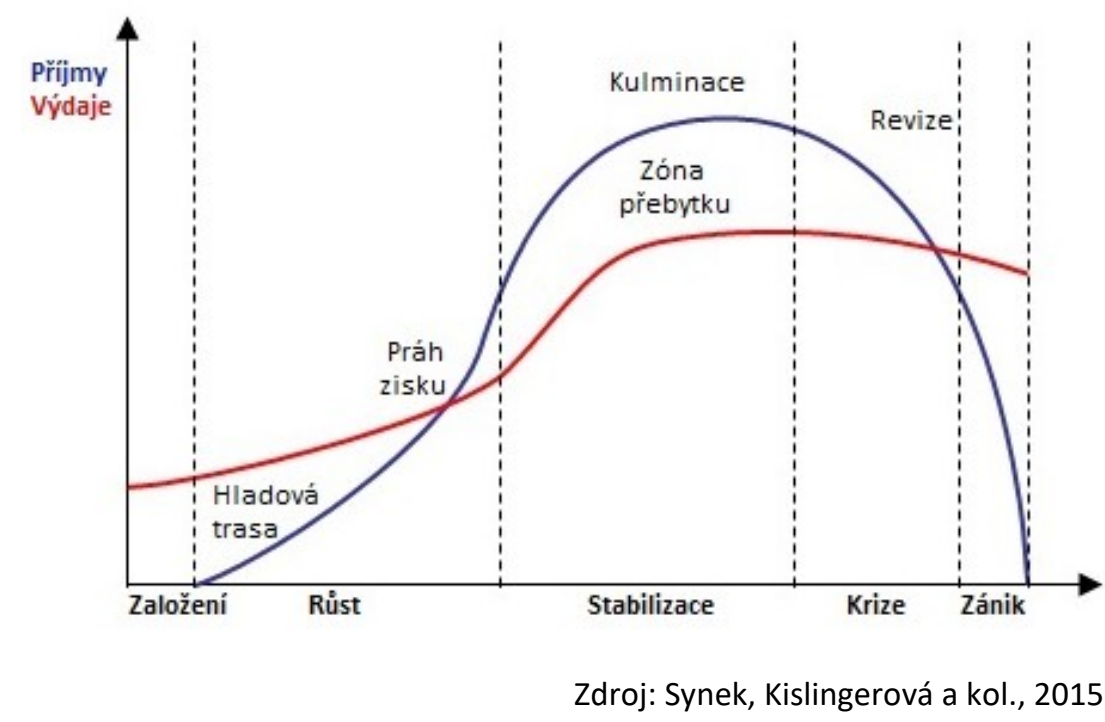

Základní hodnocení, které ovšem dokáže poměrně přesně prezentovat současnou, minulou i budoucí pozici podniku, spočívá ve finanční analýze. K finančnímu hodnocení by podniky měly využít horizontální a vertikální analýzy či poměrové analýzy - ukazatele rentability, aktivity, zadluženosti, likvidity či produktivity práce. Jedná se o klasický př́stup finanční analýzy, která je založena na analýze účetních závěrek (rozvahy, výkazu zisku a ztrát, výkazu cash flow). Existuje také moderní př́stup, který spočívá ve výpočtu ekonomické přidané hodnoty. Tento předpoklad představuje synergii s hlavním cílem podniku. Dřive to byl zisk, nyní je to ovšem hodnota podniku, kterou Ize právě pomocí ekonomické přidané hodnoty vyjádřit. Samozřejmostí by mělo být také hodnocení pomocí bankrotních a bonitních modelů, Altmanova analýza, Tafflerův model, Beermanova diskriminační funkce, Beaverův model, Indexy IN, Index bonity, Kralickův rychlý test, Grünwaldův bonitní model a další. Pro komplexnost hodnocení lze vyžít například i metody Balanced Scorecard, která spojuje čistě finanční ukazatele a ukazatele odrážející kvalitativní charakteristiky. Takové hodnocení by předmětné podniky měly zpracovávat v pravidelných sekvencích, alespoň $1 x$ ročně. 
Bližší informace kjednotlivým metodám hodnocení, jejich parametrům, způsobům výpočtu či správnému vyhodnocení Ize najít v těchto publikacích: Vochozka (2010), Vochozka (2011), Kubíčková \& Jindřichovská (2015), Vochozka a kol. (2017), Knápková a kol. (2017), Khasaev, Vochozka \& Vrbka (2018), Klieštik a kol. (2018), Růčková (2019).

Je nezbytné, aby MSP v oboru znalostně náročných služeb znaly také své okolí a svou pozici na trhu, aby si uvědomovaly rizika a naopak př́ležitosti trhu, na kterém působí. Jedná se o hodnocení mikro a makroprostředí podniku - strategickou analýzu. Je nezbytné, aby si podniky uvědomily, zda mají zpracovanou strategii. Do makroekonomického prostředí řadíme faktory ekonomické, politické, technologické, ekologické, sociální a legislativní. Do mikroprostředí naopak řadíme dodavatele, odběratele, substituty, rivalitu v oboru atd. Pro analýzu makrookolí by dotčené podniky měly využít PESTLE analýzu. Pro analýzu mikrookolí je zásadní Porterův model pěti konkurenčních sil, analýza odvětví, konkurence, zákazníků, dodavatelů či stakeholderů. Zcela základním předpokladem je využití dvou analýz, a to SWOT analýzy a Space analýzy. Použitím uvedených modelů Ize zjistit, jaké př́ležitosti či hrozby plynou pro podnik z vnějšího prostředí. Podnik získá také informace o vyjednávací síle zákazníků, vyjednávací síle dodavatelů, hrozbě vstupu nových konkurentů, hrozbě substitutů, rivalitě firem působících na daném trhu. Zjistit lze také další silné stránky, slabé stránky, př́ležitosti i hrozby. Zde Ize pro správné použití metod doporučit prostudování těchto publikací: Sedláčková \& Buchta (2006), Kim \& Mauborgne (2009), Grasseová, Dubec \& Řehák (2012), Váchal a kol. (2013), Tyll (2014), Hanzelková, Keřkovský \& Vykypěl (2017).

Komplexní analýza interního i externího prostředí podniku je základním předpokladem pro zavedení možných změn v rámci adaptace sektoru na podmínky Společnosti 4.0. Zároveň slouží jako kontrolní mechanismus, jako měřítko změn, které byly přijaty. Bohužel právě u MSP není na takové hodnocení $\checkmark$ častých prípadech kladen takový důraz, jak by si zasloužilo. Přitom by výše uvedené poznatky měly být základním předpokladem úspěšného podnikání, a to nejen v rámci adaptace podniků na podmínky Společnosti 4.0. Cílem je neustálé zlepšování finanční situace, větší obrat, stabilní pozice na trhu a kvalitní dodavatelsko-odběratelské vztahy. Analýza by měla být zpracována nejméně $1 x$ ročně, př́ípadně při každé zásadní změně ve struktuře a fungování podniku. Analýzy jsou poměrně jednoduché, vyžaduji ale dobrou znalost vnitřního i vnějšího prostředí podniku. Lze určitě doporučit minimálně konzultaci s externími společnostmi zaměřujícími se přímo na tyto aktivity. Vhodné je také diskutovat výsledky analýz se spolupracovníky, se svým týmem (napřílad pomocí brainstormingu). $Z$ takové diskuse mohou vyplynout nové nápady, které mohou zlepšit stav podniku.

Tyto analýzy bezprostředně souvisejí se sebehodnocením, které bylo prezentováno v subkapitole C.1 této Metodiky. Po spíše obecnější analýze Ize přistoupit již konkrétně k otázkám soustřed'ujícím se do oblasti adaptace na podmínky Společnosti 4.0. Pokud se podniky znalostně náročných služeb chtějí na tyto podmínky úspěšně adaptovat, měly odpovědět na několik zásadních otázek, které prímo souvisejí s potřebnou adaptací. Podniky budou dostatečně připravené, pokud budou mít připravené plány profesního růstu všech pracovníků - plány, které je připraví na předpokládané změny a vybaví je požadovanými kompetencemi. Dále je zásadní znát digitální kompetence pracovníků, či jaké prostředky kooperativní práce podniky využívají. Zásadní je také stav infrastruktury, který by měl být dostatečný pro zvládnutí digitalizace. Zpětnou vazbu potřebnou pro zajištění adaptace na podmínky Společnosti 4.0 Ize získat pomocí krátkého dotazníku - tabulky 2 a 3 v subkapitole C.1 této Metodiky. Podnik se tímto seznámí se svou pozicí a aktuálním stavem - at' už v rámci př́pravy nebo při samotné adaptaci. Na základě analýz a zjištění současného stavu Ize identifikovat přiležitosti. Poté přichází na řadu posoudit jejich náklady a rizika. Jestliže budou očekávané př́nosy vyšší než náklady a rizika budou přijatelná, bude potřeba vypracovat inovační projekt a pustit se do jeho realizace.

Klíčovou roli v rámci adaptace sektoru znalostně náročných služeb na Společnost 4.0 sehrává personální ř́zení. $\mathrm{K}$ tomuto účelu je zapotřebí, aby podnik stanovil základní zásady personálního 
řízení. Zásadní je především oblast výběru a vzdělávání a rozvoje pracovníků. V oblasti vzdělávání a rozvoje pracovníků je nutné především zvyšování kvalifikace v oblasti digitálních a informačních technologií. Dále je žádoucí podporovat zaměstnance v rozvíjení analytického myšlení, v emoční inteligenci, ICT gramotnosti, schopnosti leadershipu atd. (Caha \& Urban, 2020). Zásadní jsou také požadavky na pracovní místa. Je nutné mít přesně definované požadavky na pracovní místa. Zaměstnáním pracovníka s požadovanými vlastnostmi, schopnostmi a dovednostmi ušetříme nejen spoustu času, ale i finančních prostředků, které by bylo nutné použít pro zvýšení kvalifikace (i tato forma je ovšem pro podnik z hlediska dlouhodobější spolupráce velmi prínosná a promítne se ve větší produktivitě apod.).

Zásadní je získávání zdrojů. Podnik může využívat jednak vlastních zdrojů nebo čerpat finanční podporu z externích zdrojů. Lze využít bankovních úvěrů nebo různých podpor ze státních a veřejných rozpočtů. $V$ rámci kohezní politiky je mnoho programů a výzev otevřených pouze pro MSP. U těchto výzev je také pro MSP vyšší míra podpory. V programovém období 2021+ se počítá $s$ ještě významnějším omezením podpory pro velké podniky, proto bude statut MSP stále důležitějším faktorem při využívání evropských strukturálních a investičních fondủ. Co se týká finanční oblasti, zde závisí také na objemu prostředků vynaložených na V\&V. Právě to je dalším vhodným způsobem získávání zdrojů. Jedná se o spolupráci s výzkumnými organizacemi (například využívání inovačních voucherů). Tento objem by měl být přimo úměrný počtu vytvořených inovativních produktů a procesů ( $v$ mnoha publikacích je však zpochybňováno). Podnik by se měl zamyslet nad tím, kolik ročně investuje právě do získávání externích výsledků V\&V.

Adaptaci na podmínky Společnosti 4.0 mohou řídit samotní majitelé podniků znalostně náročných služeb, zejména v prípadě mikropodniků. Existuje již celá řada dokumentů, informací, díky nimž adaptaci Ize zvládnou v podstatě samostatně. Tato Metodika je také jedním z vhodných zdrojů pro adaptaci. Bohužel většina vrcholových manažerů na tuto činnost nenajde dostatek času a bude nucena řešit adaptaci určitým outsourcingem. Pokud se jedná o společnost, která má zavedenou pozici controllera, Ize nastavit, aby adaptaci na podmínky Společnosti 4.0 kompletně ŕídil právě on. Úloha controllera se mění s tím, jak roste význam analýzy dat. Také některé rutinní úkoly controllera Ize vyř́́dit automatizací. Controller bude ale vždy osobou, která data interpretuje, opravuje a navrhuje opatření. To může dělat i s podporou umělé inteligence, jedním z faktorů Průmyslu 4.0. Pro MSP ovšem zvládnutí těchto nástrojů může být složité. Controller musí více než kdo jiný identifikovat, které faktory určují zisk a úspěch podniku, a které naopak ne. Proto by pozice controllera měla být styčnou osobou zajištujujicí hladký přechod ke Společnosti 4.0. Je ovšem dưležité, aby $v$ podniku byli se samotnou adaptací seznámeni všichni zaměstnanci. Využít Ize také služeb externího controllera či specializovaných firem. Na přechod k Průmyslu 4.0 se zaměřují např́klad firmy:

- $\quad$ https://www.firma40.cz/;

- https://www.prumysl-4.cz/;

- $\quad$ https://www.certicon.cz/prumysl-4-0/;

- $\quad$ http://firma4.cz/.

\section{Fáze adaptace}

V první fázi podnik určí zodpovědnou osobu ( $v$ mikropodnicích a malých podnicích podnicích), popř. sestaví expertní tým (ve středních podnicích) pro oblast adaptace podniku na podmínky Společnosti 4.0. Určená osoba/expertní tým se detailně seznámí s obsahem předložené Metodiky.

V následující fázi podnik realizuje sebehodnocení s využitím nástrojů uvedených v subkapitole C.1 a v této kapitole (fáze životního cyklu, provedení analýz, realizace sebehodnocení pomocí dotazníku). $\checkmark$ této fázi bude zjištěn současný stav adaptace podniku na podmínky Společnosti 4.0. Výsledkem bude především identifikace slabých a silných stránek podniku. 
Zodpovědná osoba/expertní tým stanovuje pro určený časový horizont kličové indikátory (metriky), kterých by mělo být dosaženo (např. změna struktury financování nebo tvorba jednotných nástrojů personálního řízení - výběr zaměstnanců, jejich vzdělávání a rozvoj či outsourcing procesů).

S ohledem na zjištěné slabé a silné stránky stavu adaptace stanoví vedení podniku kroky/opatření, která povedou ke zlepšeni/urychlení adaptace podniku:

a) v krátkodobém časovém horizontu,

b) ve střednědobém časovém horizontu,

c) v dlouhodobém časovém horizontu.

Zodpovědná osoba/expertní tým bude kontinuálně monitorovat plnění stanovených kroků/opatření, a to na základě předem stanovených indikátorů a pravidelně (ročně) podávat report vedení podniku (Obr. 16).

Uvedená opatření a přijmutí uvedených informací a návrhů za své umožní MSP v oblasti znalostně náročných služeb v ČR stabilizaci, rozvoj a konkurenceschopnost; hodnocení a nastavení finančních ukazatelů a toků; zvýšení inovační aktivity a potenciálu; projekci podnikové architektury; generování reálné podnikové strategie; sní̌ení nákladů za legislativně-právní oblast; zefektivnění procesu žádání o dotace; zhodnocení potenciálu obchodních partnerů; zefektivnění personálního řízení a poznání a využití vnějšího prostředí.

Obr. 16: Adaptační fáze podniku

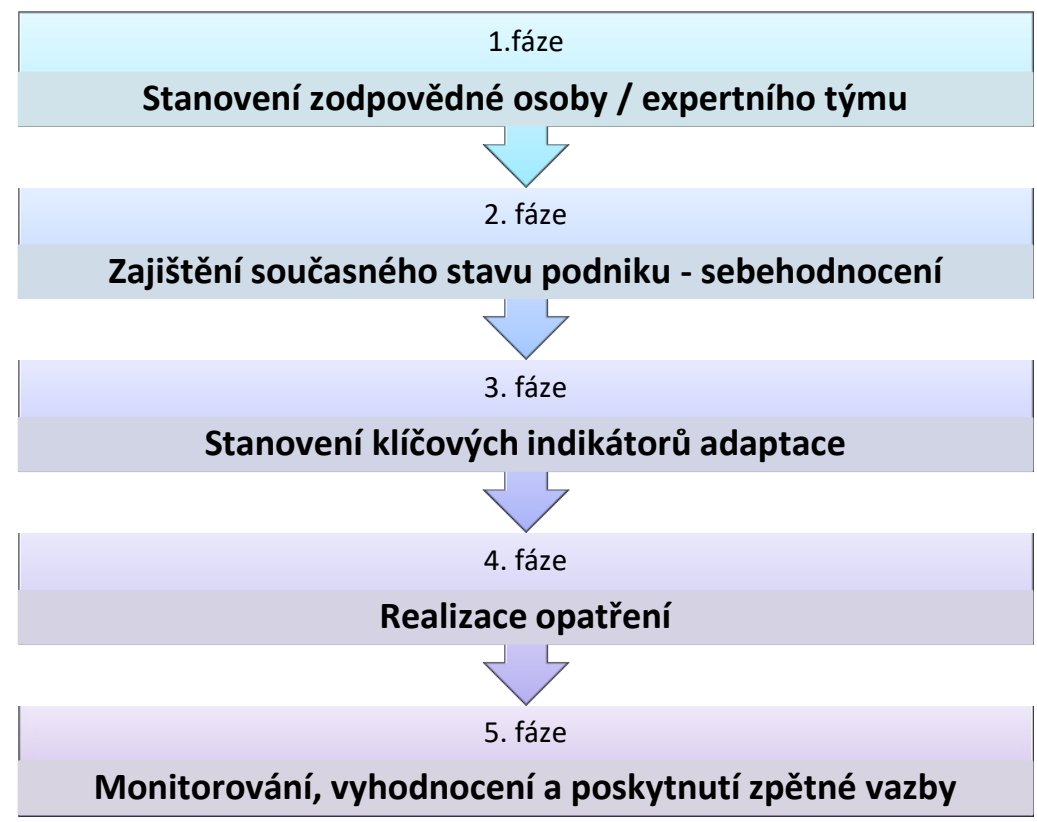

Zdroj: vlastní zpracování, 2020 


\section{SHRNUTÍ/SUMMARY}

Metodika adaptace malých a středních podniků v sektoru služeb na implementaci principů, postupů, metod a nástrojů Společnosti 4.0 vychází z výzkumu zahrnujícího analýzu a hodnocení principů, postupů, metod a nástrojů pro adaptaci sektoru služeb na technické, ekonomické, sociální a environmentální podmínky Společnosti 4.0, dále analýzu a hodnocení změn znalostních a dovednostních kvalifikačních požadavků na pracovní sílu v prostředí Společnosti 4.0, dotazníkové šetření, řizené rozhovory, analýzu a hodnocení výsledků workshopů projektu a analýzu, hodnocení a integraci podnětů a připomínek šesti externích aplikačních garantů projektu. Na tomto podkladě byla provedena syntetizace poznatků a koncepce návrhu opatření pro adaptaci malých a středních podniků v sektoru služeb na podmínky Společnosti 4.0.

Metodika má za cíl vytvořit účinný a ucelený nástroj určený pro malé a střední podniky v sektoru služeb, zaměřených na poskytování znalostně náročných služeb, $\mathrm{k}$ adaptaci na podmínky Společnosti 4.0. Včasná a efektivní realizace koncepce Průmyslu 4.0 a Společnosti 4.0 v malých a středních podnicích $v$ sektoru služeb je v posledních deseti letech aktuální fenomén související na jedné straně s rychlým nástupem automatizace, robotizace, elektronizace a digitalizace ve výrobních a nevýrobních odvětvích velkých podniků a na druhé straně s bariérami lidských, finančních, znalostních a časových zdrojů vyplývajících z charakteru a specifik malých a stredních podniků v sektoru služeb.

Navržená Metodika byla konzultována, vytvořena a následně bude ověřována a testována v podnikové praxi na vybraném vzorku podniků ve spolupráci se šesti externími aplikačními garanty projektu (Krajská hospodářská komora v Plzeňském kraji; Úřad práce ČR, krajská pobočka v Plzni; Úřad práce ČR, krajská pobočka v Českých Budějovicích; Jihočeská hospodářská komora; Krajský úřad Jihočeského kraje; Jihočeská společnost pro rozvoj lidských zdrojů, o.p.s.). Z vyjádření externích aplikačních garantů k Metodice Ize konstatovat, že obsah a postup navržené Metodiky korespondují s potřebami a požadavky malých a středních podniků v sektoru služeb. Využití Metodiky by mělo přispět ke zvýšení produktivity a kvality práce a kvyužití konkurenčních výhod souvisejícími s technologiemi a nástroji Společnosti 4.0 a ke zvýšení znalostního potenciálu a motivace vlastníků, manažerů a zaměstnanců malých a středních podniků v sektoru služeb.

\section{Přenositelnost navržené Metodiky adaptace malých a středních podniků v sektoru služeb na implementaci principů, postupů, metod a nástrojů Společnosti 4.0}

Empirický výzkum realizovaný v rámci projektu TA ČR a jeho výsledky dokumentované v kapitole $B$ a C Metodiky byl proveden na území České republiky v Plzeňském a Jihočeském kraji v prostředí malých a středních podniků v sektoru služeb. Navrženou Metodiku Ize aplikovat a transformovat podle konkrétních potřeb a požadavků mikro, malých a středních podniků v sektoru služeb nejen v České republice, ale i ve střední Evropě, zejména na Slovensku, v Polsku a Mad'arsku, a to z důvodu podobného legislativního rámce pro MSP a stavu, trendu vývoje a rostoucího významu MSP $v$ těchto zemích. Navržená Metodika a potenciál jejího využití pro MSP představuje aktuální metodický postup podporující stabilitu a ekonomický rozvoj MSP v době po překonání celosvětové pandemie COVID-19. Metodika může také sloužit jako motivační a znalostní návod pro MSP voblasti identifikace a hodnocení přiležitostí a hrozeb v kontextu podmínek Společnosti 4.0.

\section{Poděkování}

Autorský tým Metodiky děkuje všem šesti externím aplikačním garantům za spolupráci, připomínky a doporučení ke struktuře a obsahu Metodiky a za jejich odborný př́nos a zpětnou vazbu při tvorbě Metodiky. 


\section{SUMMARY}

The methodics of adaptation of small and medium sized enterprises (SMEs) in tertiary sector to implementation of principles, procedures, methods and tools of Society 4.0 is based on research including analysis and evaluation of principles, procedures, methods and tools for tertiary sector adaptation to technical, economic, social and environmental conditions of Society 4.0, further analysis and evaluation of changes in knowledge and skills qualification requirements on working capital in Society 4.0 environment, questionnaire survey, interviews, analysis and evaluation of project workshop results and analysis, evaluation and integration of suggestions and comments of six external application guarantors. Using this basis, synthesis of knowledge and concept of proposal of measures for the adaptation of SMEs in tertiary sector to the conditions of Society 4.0 were conducted.

The aim of the Methodics is to create effective and complex tool designed for SMEs in tertiary sector focused on providing knowledge-intensive services to help them with adaptation on Society 4.0 conditions. Timely and effective implementation of Industy 4.0 and Society 4.0 concept by SMEs in tertiary sector is a current phenomenon in the last ten years. It is associated with rapid onset of automation, robotics, electronics and digitization in manufacturing and non-manufacturing industries, but also with barriers to human, financial, knowledge and time resources resulting from the nature and specifics of SMEs in tertiary sector.

The proposed Methodics was consulted, created and will be verified and tested, in cooperation with six external application guarantors of the project (Krajská hospodářská komora v Plzeňském kraji; Úřad práce ČR, krajská pobočka v Plzni; Úřad práce ČR, krajská pobočka v Českých Budějovicích; Jihočeská hospodářská komora; Krajský úřad Jihočeského kraje; Jihočeská společnost pro rozvoj lidských zdrojů, o.p.s.), in business practice on a selected sample of enterprises. Based on the comments of six external application guarantors on the Methodics can be stated that content and procedure of the Methodics correspond to the needs and requirements of SMEs in tertiary sector. Use of the Methodics should contribute to increase of productivity and quality of work and to the use of competitive advantages associated with technologies and tools of Society 4.0 and to the increase of knowledge potential and motivation of owners, managers and employees of SMEs in tertiary sector.

\section{Transferability of the proposed Methodics of SMEs in tertiary sector adaptation on implementation of principles, procedures, methods and tools of Society 4.0}

Empirical research conducted within the project TAČR, its results are described in chapter $B$ of the Methodics, was realized in the Czech Republic, in the Pilsen and South Bohemia region in the SMEs in tertiary sector environment. The proposed Methodics can be applied and transformed in accordance with the specific needs and requirements of micro, small and medium-sized enterprises in tertiary sector not only in the Czech Republic, but also in Central Europe, especially in Slovakia, Poland and Hungary, due to the similar legislative framework for SMEs and the state, development trend and growing importance of SMEs in these countries. The proposed Methodics and potential of its use by SMEs represent current procedure supporting stability and economic development of SMEs after ovecoming the global pandemic COVID-19. The Methodics can be also used as the motivational and knowledge guideline for SMEs in identification and evaluation of opportunities and threats in the context of Society 4.0 conditions.

\section{Thank you note}

The team of authors of the Methodics thanks all six external application guarantors for their cooperation, comments and recommendations to structure and content of the Methodics and for their professional contribution and feedback during its compilation. 


\section{E SEZNAM TABULEK A OBRÁZKŮ}

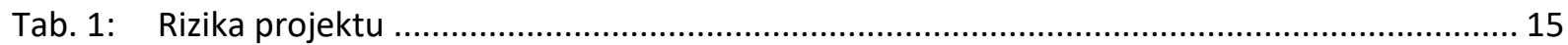

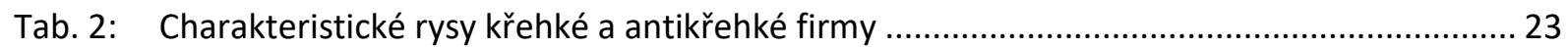

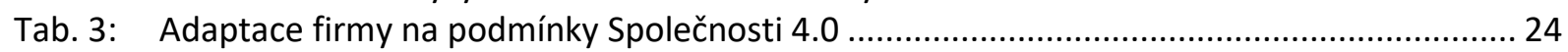

Tab. 4: Kategorie osvojitelů v Rogersově modelu difuze inovací ....................................................... 34

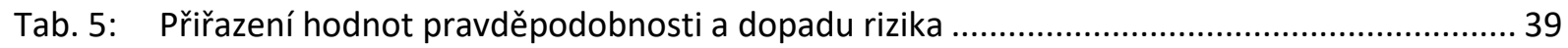

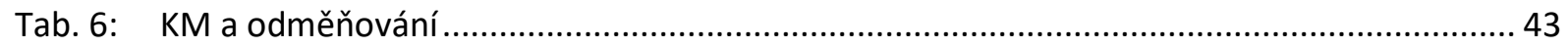

Tab. 7: Nástroje Společnosti 4.0 využitelné k optimalizaci podnikových činností............................. 47

Tab. 8: Check-list pro podniky - souhrn opatření v oblasti zaměstnanosti

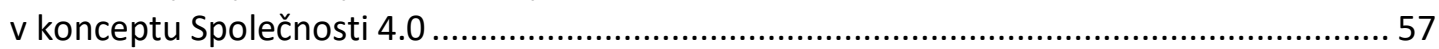

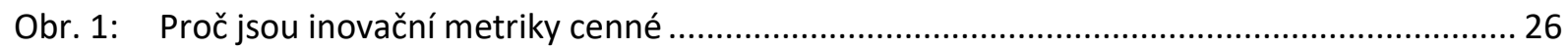

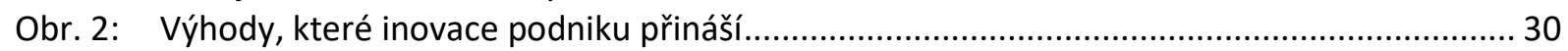

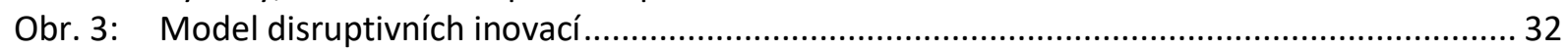

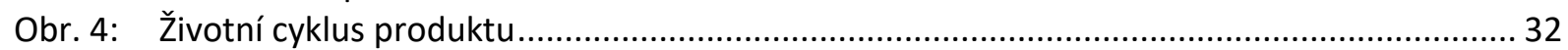

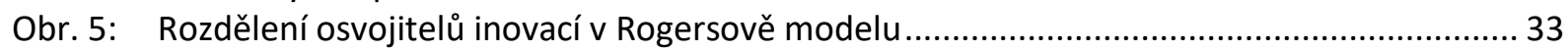

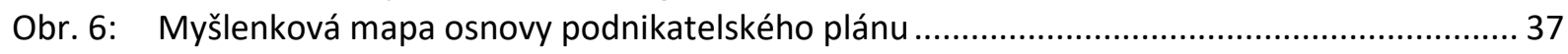

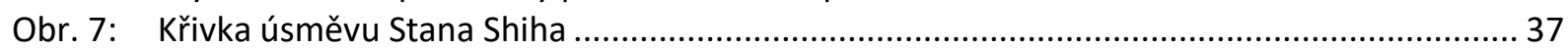

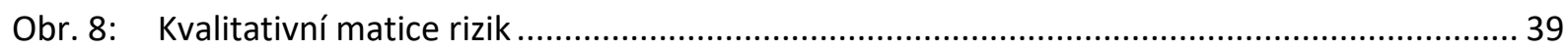

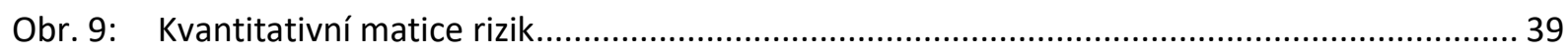

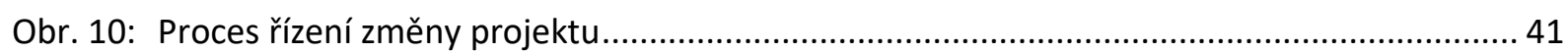

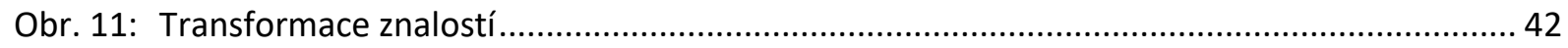

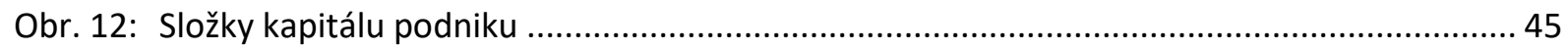

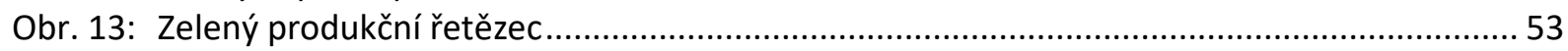

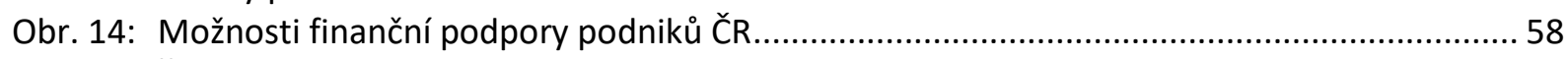

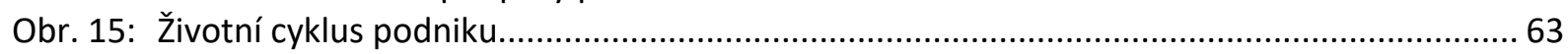

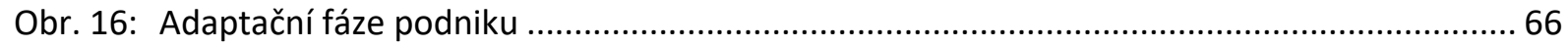




\section{F POPIS UPLATNĚNÍ METODIKY}

Metodika adaptace malých a středních podniků v sektoru služeb na implementaci principů, postupů, metod a nástrojů Společnosti 4.0 bude sloužit především jako návod $\mathbf{k}$ postupu řešení adaptace mikro, malých a středních podniků na podmínky Společnosti 4.0. Metodika může být uplatněna také jako motivační a znalostní nástroj a návod pro malé a střední podniky voblasti identifikace a hodnocení príležitostí a hrozeb souvisejících s rozvojem technických, ekonomických, sociálních a environmentálních podmínek v prostředí Průmyslu 4.0 a Společnosti 4.0. Dále pak může být využívána při činnosti a akcích externích aplikačních garantů projektu „Adaptace sektoru znalostně náročných služeb na podmínky Společnosti 4.0" (TL02000136) a ostatních institucí. Metodika je veřejně př́stupná na webových stránkách projektu (https://azis.zcu.cz/).

\section{Principy aplikace metodiky}

Metodika je určena pro pracovníky malých a středních podniků kompetentními v oblasti realizace koncepce Průmysl 4.0 a Společnost 4.0. Předpokládá znalost problematiky nebo využití dílčích výstupů projektu dokumentovaných ve dvou publikacích „Identifikace, analýza a hodnocení principů, postupů, metod a nástrojů pro adaptaci sektoru služeb na technické, ekonomické, sociální a environmentální podmínky Společnosti 4.0" (Vacek a kol., 2019) a "Katalog změn znalostních a dovednostních kvalifikačních požadavků na zaměstnanecké pozice v souvislosti s nástupem a rozvojem Společnosti 4.0" (Taušl Procházková a kol., 2019). 


\section{G POUŽITÁ LITERATURA A ZDROJE}

Agentura pro podnikání a inovace. (2020). Programy podpory. Dostupné květen 19, 2020, $\mathrm{z}$ https://www.agentura-api.org/cs/programy-podpory/.cz.

Azhar, A., \& Droog, C. (2019). Resilience is a skill that's just as important as tech know-how. Dostupné duben 20, 2020, z https://www.strategy-business.com/blog/Resilience-is-a-skill-thats-just-asimportant-as-tech-know-how.

BCG. (2006). Measuring Innovation 2019. Boston Consulting Group. Dostupné duben 20, 2020, z http://www.bcg.com/documents/file15484.pdf.

Belás, J., Ivanová, E., Sobeková Májková, M., \& Strenitzerová, M. (2014). Ekonomika a management podniku. Žilina: GEORG.

Bic.cz. (2020). Partnerství znalostního výzkumu. Dostupné květen 21, 2020, z https://www.bic.cz/novinky/partnerstvi-znalostniho-transferu-pata-vyzva.

Blank, S. (2020). How To Keep Your Company Alive - Observe, Orient, Decide and Act. Dostupné duben 15, 2020, z https://steveblank.com/2020/04/01/the-ceo-playbook-for-keeping-vour-companyalive/.

Business.info. (2016). Průmysl 4.0 představuje pro malé a střední firmy př́ležitost, ale i rizika. Dostupné duben 20, 2020, z https://www.businessinfo.cz/clanky/prumysl-40-predstavuje-pro-malea-stredni-firmy-prilezitost-ale-i-rizika/.

Caha, Z., \& Urban, J. (2020). Human Resource Management in SMEs in the Czech Republic - Specifics and Key Requirements. SHS Web of Confereces: Innovative Economic Symposium 2019 - Potencial of Eurasian Economic Union (IES2019). České Budějovice: Czech Republic, doi.org/10.1051/shsconf/20207302001.

CB Insights. (2019). Al 100: The Artificial Intelligence Startups Redefining Industries. Dostupné duben 20, 2020, z https://www.cbinsights.com/research/5g-technology-disrupting-industries/.

Centrum andragogiky. (2017). Průmysl 4.0 - ne hrozba, ale přiležitost - diskuzní dopoledne u nás $v$ Centru andragogiky. Dostupné duben 19, 2020, z http://www.centrumandragogiky.cz/prumysl-4-0ne-hrozba-ale-prilezitost-diskuzni-dopoledne-u-nas-v-centru-andragogiky/.

Cingl, O. (2012). Řízení procesu změny. Dostupné květen 12, 2020, $\mathrm{z}$ http://www.projektmanazer.cz/kurz/soubory/modul-c/c2.pdf.

CVCA.cz. (2020). Asociace CVCA. Dostupné květen 25, 2020, z https://cvca.cz/.

ČMZRB. (2020). Finanční podpora podniků. Dostupné květen 15, 2020, z https://www.cmzrb.cz/ podnikatele/.

ČSJ. (2019). Zbrusu nový Model EFQM je tady. Česká společnost pro jakost. Dostupné duben 20, 2020, $\mathrm{z}$ https://www.csq.cz/model-efqm/.

Deloitte. (2018). Automatizace práce v ČR. Proč se (ne)bát robotů? Dostupné květen 5, 2020,

$\mathrm{z}$ https://www2.deloitte.com/content/dam/Deloitte/cz/Documents/strategyoperations/Automatizace-prace-v-CR.pdf.

Deloitte. (2017a). Deloitte Insights. Forces of change: Industry 4.0. A Deloitte series on Industry 4.0. Dostupné duben 18, 2020, z www.deloitte.com/Insights. 
Deloitte. (2017b). Automation is here to stay...but about your workforce? Preparing your organizationfor the new worker ecosystem. Dostupné květen 27, 2020,

$\mathrm{z}$ https://www2.deloitte.com/cz/cs/pages/strategy-operations/solutions/robotic-process-

automation.html.

Doležal, J., et al. (2016). Projektový management: Komplexně, prakticky a podle světových standardů. Praha: Grada.

DotaceEU.cz. (2020). Projekt INTERREG. Dostupné květen 20, 2020, z https://www.dotaceeu.cz/cs/fondy-eu/2014-2020/operacni-programy/op-interreg-europe.

EC. (2006). RICARDIS - Reporting Intellectual Capital to Augment Research, Development and Innovation in SMEs. European Communities. Dostupné duben 20, 2020,

$\mathrm{z}$ https://ec.europa.eu/invest-in-research/pdf/download en/2006-2977 web1.pdf.

European Commission. (2020). Př́stup malých a středních podniků k financování. Dostupné květen 22, 2020, z https://ec.europa.eu/info/sites/info/files/file import/european-semester thematicfactsheet small-medium-enterprises-access-finance cs.pdf.

Evropská komise. (2018). Akční plán digitálního vzdělávání. Dostupné březen 31, 2020, $\mathrm{z}$ https://ec.europa.eu/education/education-in-the-eu/digital-education-action-plan cs.

Fundchaser.com. (2020). Crowdfunding. Dostupné květen 15, 2020, z https://fundchaser.com/cs/ crowdfunding-cs/jak-vlastne-funguje-crowdfunding-a-co-od-neho-cekat/.

Grasseová, M., Dubec, R., \& Řehák, D. (2012). Analýza podniku v rukou manažera. 2. vyd. Brno: BizBooks.

Hanzelková, A., Keřkovský, M., \& Vykypěl, O. (2017). Strategické ř́zení. 3. přepracované vyd. Praha: C.H. Beck.

HitHit. (2020). Projekty. Dostupné květen 10, 2020, z https://www.hithit.com/cs/search.

Hyperfinance.cz. (2020). Business angel. Dostupné květen 15, 2020, z https://www.hyperfinance.cz /magazin/business-angel-slyseli-jste-o-nem/.

Chaitravi. (2010). The Smiling Curve: Stan Shih. Dostupné duben 20, 2020,

z https://chaitravi.wordpress.com/2010/02/10/the-smiling-curve-stan-shih/.

Chesbrough, H. W. (2006). Open innovation: the new imperative for creating and profiting from technology. Boston: Harvard Business School Press.

Chmelař, A. et al. (2015). Dopady digitalizace na trh práce $v$ ČR a EU. Oddělení strategie a trendů Evropské unie (OSTEU). Dostupné květen 27, 2020, z https://www.vlada.cz/assets/evropskezalezitosti/analyzy-EU/Dopady-digitalizace-na-trh-prace-CR-a-EU.pdf.

Chung, D. B., Jang, H. J., \& Kim, B. (2019). The effects of business environments on innovation activity and firm performance based on workplace panel survey of South Korea. 2019 Portland International Conference on Management of Engineering and Technology (PICMET). Portland: USA.

Christensen, C. M., Hall, T., Dillon, T., \& Duncan, D. S. (2016). Know Your Customers' "Jobs to Be Done". Harvard Business Review, 2016(9), 54-62.

Christensen, C. M. (2003). The innovator's dilemma. New York: HarperCollins.

Churchill, J., von Hippel, E., \& Sonnack, M. (2009). Lead user project handbook: A practical guide for lead user project teams. Dostupné duben 20, 2020,

$\mathrm{z}$ https://evhippel.files.wordpress.com/2013/08/lead-user-project-handbook-full-version.pdf. 
Institut cirkulární ekonomiky. (2018a). Cirkulární ekonomika. Dostupné duben 20, 2020, $\mathrm{z}$ https://incien.org/.

Institut cirkulární ekonomiky. (2018b). Cirkulární Česko: Cirkulární ekonomika jako príležitost pro úspěšné inovace českých firem. Dostupné duben 20, 2020, z https://incien.org/wpcontent/uploads/2018/08/WP CE.pdf.

ITbiz.cz. (2020). Digitalizace se vyplácí, podnikovým službám přináší $i$ v době pandemie nové přiležitosti. Dostupné duben 20, 2020, z https://www.itbiz.cz/tiskove-zpravy/digitalizace-se-vyplacipodnikovym-sluzbam-prinasi-i-v-dobe-pandemie-nove-prilezitosti.

Jirásek, J. (2020). Investiční aktivita na nule, nebo jedinečná šance? Bankovnictví, 2020(4), 19-20.

Kane, G. C., Phillips, A. N., Copulsky, J. R., \& Andrus, G. R. (2019). The Technology Fallacy: How People Are the Real Key to Digital Transformation. Cambridge, MA: MIT Press.

Kaplan, R., \& Norton, D. (2001). Balanced Scorecard. 2. vydání. Praha: Management Press.

Khasaev, G., Vochozka, M., \& Vrbka, J. (2018). Creating a comprehensive enterprise evaluation method. 1. vyd. České Budějovice: Institute of Technology and Business in České Budějovice.

Kim, W. Ch., \& Mauborgne, R. (2009). Strategie modrého oceánu: umění vytvořit si svrchovaný tržní prostor a vyřadit tak konkurenty ze hry. Praha: Management Press.

Kim, W. Ch., \& Mauborgne, R. (2004). Blue Ocean Strategy. Harvard: Harvard Business Publishing.

Klieštik, T., Klieštiková, J., Kováčová, M., Švábová, L., Valášková, K., Vochozka, M., \& Oláh, J. (2018). Prediction of financial health of business entities in transition economies. 1. vyd. New York: Addleton Academic Publishers.

Knápková, A., Pavelková, D., \& Šteker, K. (2017). Finanční analýza - komplexní průvodce s príklady. 3. kompletně aktualizované vyd. Praha: Grada Publishing, a.s.

Kohout, P., \& Palíšková, M. (2017). Dopady digitalizace, automatizace a robotizace. Praha: ASO.

Košturiak, J. (2019): Poznámky ke knize Antifragilita. Dostupné květen 18, 2020,

z https://zoom.rba.cz/clanky/jan-kosturiak-poznamky-ke-knize-antifragilita.

Kruliš, K. (2018). Společnost 4.0. v České republice. Dostupné květen 9, 2020,

$\mathrm{z}$ http://www.amo.cz/wp-content/uploads/2018/06/AMO spolecnost-4.0-v-ceske-republice.pdf.

Kubíček, J., \& Svačina, P. (2006). Průmyslová práva a nehmotné statky, jejich licenční využití a oceňování. TC AV ČR. Dostupné duben 20, 2020,

$\mathrm{z}$ https://cpi.vsb.cz/export/sites/cpi/.content/galerie-souboru/prumyslova-prava.pdf.

Kubíčková, D., \& Jindřichovská, I. (2015). Finanční analýza a hodnocení výkonnosti firem. 1. vyd. Praha: C.H. Beck.

Liebowitz, J. (editor). (2009). Knowledge Management Handbook. USA: CRC Press.

Likens, S. (2019). The Essetial Eight. Dostupné duben 20, 2020,

z https://www.pwc.com/gx/en/issues/technology/essential-eight-technologies.html.

Lipavský, J. (2020). Nezadusme náš zdravotnický průmysl čínskými dovozy. Dostupné duben 20, 2020, z http://blog.aktualne.cz/blogy/jan-lipavsky.php?itemid=36360.

Maurya, A. (2012). Why Lean Canvas vs Business Model Canvas. Dostupné duben 20, 2020, $\mathrm{z}$ https://blog.leanstack.com/why-lean-canvas-vs-business-model-canvas-af62c0f250f0.

Mládková, L. (2004). Management znalostí v praxi. Praha: Professional Publishing. 
MPO. (2020a). Program záruka 2015 až 2023. Dostupné květen 10, 2020, z https://www.mpo.cz /cz/podnikani/dotace-a-podpora-podnikani/narodni-programy-na-podporu-msp/zaruka/programzaruka-2015-az-2023--249745/.

MPO. (2020b). Program VADIUM. Dostupné květen 5, 2020, z https://www.mpo.cz/cz/podnikani/ dotace-a-podpora-podnikani/narodni-programy-na-podporu-msp/program-vadium-201-az-2023-238577/.

MPO. (2020c). Program Inostart. Dostupné květen 7, 2020, z https://www.mpo.cz/cz/podnikani /dotace-a-podpora-podnikani/narodni-programy-na-podporu-msp/inostart/program-inostart-249744/.

MPO. (2020d). Program Trio. Dostupné květen 1, 2020, z https://www.mpo.cz/assets/cz/ podnikani/podpora-vyzkumu-a-vyvoje/2018/5/Text-programu-TRIO_zneni-od-30-04-2018.pdf.

MPO. (2020e). Nové balíčky služeb pro digitalizaci. Dostupné květen 3, 2020,

z https://www.mpo.cz/cz/rozcestnik/pro-media/tiskove-zpravy/na-zaklade-vyzvy-mpo-vznikly-novebalicky-sluzeb-pro-digitalizaci---254126/.

MPO. (2020f). Iniciativa Průmysl 4.0. Dostupné květen 2, 2020, z https://www.mpo.cz/assets/ dokumenty/53723/64358/658713/priloha001.pdf.

MPO. (2015). Národní inciativa Průmysl 4.0. Dostupné květen 9, 2020,

z https://www.mpo.cz/assets/dokumenty/53723/64358/658713/priloha001.pdf.

MPSV. (2016). Inciativa Práce 4.0. Dostupné květen 9, 2020, z https://www.mpsv.cz/web/cz/prace-4.0.

Mú Plzeň - Doubravka. (2020). Mikrogranty. Dostupné květen 17, 2020,

z https://umo4.plzen.eu/urad-a-samosprava/transparentni-urad/dotace/.

Národní portál pro evropský výzkum. (2020). Rámcové programy. Dostupné květen 20, 2020,

z https://www.evropskyvyzkum.cz/cs/nastroje-spoluprace/ramcove-programy.

Obnovitelně.cz. (2020). Krize je také přiležitost. Nová ekonomika bude stát na high-tech zelených technologiích. Dostupné duben 19, 2020, z https://www.obnovitelne.cz/cz/clanek/1154/krize-jetake-prilezitost-nova-ekonomika-bude-stat-na-high-tech-zelenych-technologiich/.

Odbory.info. (2017). V príštích patnácti letech zanikne kvůli digitalizaci 40 až 50 procent pracovních míst. Dostupné květen 27, 2020, z https://www.odbory.info/obsah/5/v-pristich-patnacti-letechzanikne-kvuli-digitalizaci-40-az/20739.

OECD. (2018). Oslo Manual 2018: Guidelines for Collecting, Reporting and Using Data on Innovation, 4th Edition, Dostupné duben 20, 2020, z https://www.oecd.org/science/oslo-manual-20189789264304604-en.htm.

Osterwalder, A., \& Pigneur, Y. (2015). Tvorba business modelů. Praha: BizBooks.

Patent Databases. (2020). 10 Best Free and Paid Search Platforms. Dostupné duben 20, 2020, $\mathrm{z}$ https://www.greyb.com/patent-databases-best-search-platforms/.

Pavlák, M., Novotný, J., \& Vacek, J. (2017). Základy podnikání. Plzeň: Katedra podnikové ekonomiky a managementu, Fakulta ekonomická, Západočeská univerzita v Plzni.

Peters, T. (1988). Thriving from Chaos: Handbook for a Management Revolution. USA: Harper Perennial.

PortálDigi. (2017). Digitalizace - hrozba nebo príležitost? Dostupné duben 18, 2020,

$\mathrm{z}$ https://metsos.portaldigi.cz/blog/digitalizace-hrozba-nebo-prilezitost. 
Portál Pohoda. (2014). Outsourcing a jeho využití v praxi. Dostupné květen 27, 2020, z https://portal.pohoda.cz/pro-podnikatele/uz-podnikam/outsourcing-a-jeho-vyuziti-v-praxi/.

Prusa Resarch. (2020). Prusa research tiskne ochranné štíty pro lékaře. Rozdá jich desítky tisíc. Dostupné duben 20, 2020, z https://www.prusa3d.cz/prusa-research-tiskne-ochranne-stity-prolekare-rozda-jich-desitky-tisic/.

Ráb, L. (2006). Základní přehled autorského práva v České Republice. Dostupné květen 18, 2020, z http://rko.zcu.cz/file/autor.doc.

Ráb, L. (2005). Přehled základních právních predpisů upravujících právo duševního vlastnictví. Dostupné květen 18, 2020, z http://rko.zcu.cz/file/dv.doc.

Rogers, E. M. (2003). Diffusion of Innovations, 5th Edition. UK: Free Press.

Růčková, P. (2019). Finanční analýza: metody, ukazatele, využití v praxi. 6. aktualizované vyd. Praha: Grada Publishing, a.s.

Sedláčková, H., \& Buchta, K. (2006). Strategická analýza. 2. předpracované a rozšířené vyd. Praha: C.H. Beck.

Strouhal, J. (2014). Ekonomika podniku. Praha: INSTITUT CERTIFIKACE ÚČETNÍCH, a.s.

Svozilová, A. (2016). Projektový management: Systémový prístup k řízení projektů - 3. aktualizované a rozšířené vydání. Praha: Grada

Synek, M., Kislingerová, E., et al. (2015). Podniková ekonomika. 6. přepracované a doplněné vydání. Praha: C. H. Beck.

TAČR. (2020). Programy a soutěže. Dostupné květen 18, 2020, z https://www.tacr.cz/programy-asouteze/.

Taleb, N. (2014). Antifragilita: jak těžit z nahodilosti, neurčitosti a chaosu. Praha: Paseka.

Taleb, N. (2011). Černá labut': následky vysoce nepravděpodobných událostí. Praha: Paseka.

Taušl Procházková, P., Hejduková, P., Hinke, J., Horák, J., Machová, V., Vallišová, L., \& Vokoun, M. (2019). Katalog změn znalostních a dovednostních kvalifikačních požadavků na zaměstnanecké pozice $v$ souvislosti s nástupem a rozvojem Společnosti 4.0. Dostupné březen 31, 2020, z https://azis.zcu.cz.

Taušl Procházková, P. (2020). Zpráva z workshopu č. 1 „Adaptace sektoru znalostně náročných služeb na podmínky Společnosti 4.0. Dostupné březen 31, 2020, z https://azis.zcu.cz.

Tidd, J., \& Bessant, J. (2011). Innovation and Entrepreneurship. Chichester: John Wiley \& Sons Ltd.

Tyll, L. (2014). Podniková strategie. Praha: C.H. Beck.

Tucker, R. B. (2019). These Nine Powerful Technologies Are Now Ready for Rollout. Dostupné duben 20, 2020, z https://www.innovationexcellence.com/blog/2019/02/26/these-nine-powerful-technologiesare-now-ready-for-rollout/.

Turriago-Hoyos A., Thoene U., \& Arjoon, S. (2016). Knowledge Workers and Virtues in Peter Drucker's Management Theory. SAGE Open, 2016(1-3), 1-9, https://doi.org/10.1177/2158244016639631.

Ulwick, T. (2017). What Is Jobs-to-be-Done?. Dostupné duben 20, 2020, z https://jobs-to-bedone.com/what-is-jobs-to-be-done-fea59c8e39eb.

UNIDO. (2018). Industry 4.0: The opportunities behind challenges. Dostupné duben 19, 2020, $\mathrm{z}$ https://www.unido.org/gc17/industry40.

ÚPV. (2020). Úřad průmyslového vlastnictví. Dostupné duben 19, 2020, z http://www.upv.cz. 
Úřad vlády ČR. (2017a). Akční plán pro Společnost 4.0. Dostupné březen 31, 2020, $\mathrm{z}$ https://www.databaze-strategie.cz/cz/urad-vlady/strategie/akcni-plan-pro-spolecnost-4-02017?typ=struktura.

Úřad vlády ČR. (2017b). Aliance Společnost 4.0. Dostupné březen 31, 2020, z https://www.databazestrategie.cz/cz/urad-vlady/strategie/spolecnost-4-0-2017?typ=struktura.

Vacek, J., Dvořáková, L., Černá, M., Horák, J., Caha, Z., \& Machová, V. (2019). Identifikace, analýza a hodnocení principů, postupů, metod a nástrojů pro adaptaci sektoru služeb na technické, ekonomické, sociální a environmentální podmínky Společnosti 4.0. PIzeň: NAVA.

Vacek, J. (2020). Workshop-2020-01-14-Prezentace_Dotazníkové šetření.pdf. Dostupné březen 31, 2020, z https://azis.zcu.cz.

Vacek, J. (2005). Management inovací a duševní vlastnictví. Inženýrská akademie ČR. Dostupné duben 19, 2020, z https://www.kip.zcu.cz/kursy/imi/IMI2006/IAdoc JV.pdf.

Váchal, J., Vochozka, M., et al. (2013). Podnikové rízení. 1. vyd. Praha: Grada Publishing, a.s.

Veber, J., Srpová, J., et al. (2012). Podnikání malé a střední firmy. 3.vyd. Praha: Grada Publishing, a.s.

VIIMA. (2020). How to measure Innovation. Dostupné duben 20, 2020,

$\mathrm{z}$ https://www.viima.com/innovation-management-metrics-infographic.

Vláda ČR. (2010). Strategie Evropa 2020 a ČR. Dostupné březen 31, 2020, z https: //www.vlada.cz/cz/evropske-zalezitosti/evropske-politiky/strategie-evropa-2020/cr/eu-2020-a-cr78696/.

Vochozka, M. (2011). Metody komplexniho hodnocení podniku. 1. vyd. Praha: Grada Publishing, a.s.

Vochozka, M. (2010). Vývoj metod komplexního hodnocení výkonnosti podniku. Politická ekonomie, 58(5), 675-688.

Vochozka, M., Vrbka, J., Hašková, S., Rowland, Z., \& Machová, V. (2017). Přehled metod komplexního hodnocení podniků. 1. vyd. České Budějovice: Vysoká škola technická a ekonomická v Českých Budějovicích.

WEF. (2018). The Future of Jobs Report 2018. Dostupné květen 8, 2020,

$\mathrm{z}$ http://www3.weforum.org/docs/WEF Future of Jobs 2018.pdf.

Wikipedia. (2020a). Antifragilita. Dostupné květen 15, 2020,

$\mathrm{z}$ https://cs.wikipedia.org/wiki/Antifragilita.

Wikipedia. (2020b). Cirkulární ekonomika. Dostupné květen 18, 2020,

z https://cs.wikipedia.org/wiki/Cirkul\%C3\%A1rn\%C3\%AD ekonomika.

Wikipedia. (2019). Difuze inovací. Dostupné květen 18, 2020,

z https://cs.wikipedia.org/wiki/Difuze inovac\%C3\%AD.

Witassek, L. (2020). Pandemie změnila business, přizpůsobíme se nebo zůstaneme vzadu? Dostupné duben 13, 2020, z http://blog.aktualne.cz/blogy/libor-witassek.php?itemid=36489.

Woodcock, J., \& Graham, M. (2020). The Gig Economy: A Critical Introduction. Cambridge, UK: Polity Press.

ZČU. (2020). 25. Veletrh pracovních přiležitostí. Dostupné květen 21, 2020,

$\mathrm{z}$ https://veletrh.zcu.cz/cs/.

ZČU. (2004). U-SME Innovation: Design of a model for joint University - Enterprise Innovation. Dostupné květen 17, 2020, z https://www.kip.zcu.cz/USME/index.html.

Žižka M., Rydvalová P., \& Jáč, I. (2005). Inovace v malém a středním podnikání. Praha: BizBooks. 


\section{H SEZNAM AKTIVIT PŘEDCHÁZEJÍCÍCH METODICE}

\section{Publikace}

Taušl Procházková, P., Hejduková, P., Hinke, J., Horák, J., Machová, V., Vallišová, L., \& Vokoun, M. (2019). Katalog změn znalostních a dovednostních kvalifikačních požadavků na zaměstnanecké pozice $v$ souvislosti s nástupem a rozvojem Společnosti 4.0. Dostupné březen 31, 2020, z https://azis.zcu.cz.

Taušl Procházková, P. (2020). Zpráva z workshopu č. 1 „Adaptace sektoru znalostně náročných služeb na podmínky Společnosti 4.0. Dostupné březen 31, 2020, z https://azis.zcu.cz/.

Vacek, J., Dvořáková, L., Černá, M., Horák, J., Caha, Z., \& Machová, V. (2019). Identifikace, analýza a hodnocení principů, postupů, metod a nástrojů pro adaptaci sektoru služeb na technické, ekonomické, sociální a environmentální podmínky Společnosti 4.0. Plzeň: NAVA. Dostupné březen 31, 2020, z https://azis.zcu.cz.

\section{Články}

Hinke, J., Vokoun, M., Černá, M., Dvořáková, L., \& Caha, Z. (2019). Typology of Knowledge-Intensive Services for the Purposes of Adaptation to the Conditions of Society 4.0: Case Study of the Czech Republic. In Khalid S. Soliman (Ed.), Proceedings of the 33rd International Business Information Management Association Conference (IBIMA). Spain: Granada, 1887-1898. Retrieved January 30, 2020, from https://drive.google.com/drive/folders/1tfuJAkJuGdl3R4l17zioZdTij64LmPCV.

Dvořáková, L. (2019). Průmysl 4.0 - Společnost 4.0 - Na cestě ke Společnosti 5.0. Účetnictví, 6/2019,7-11.

Trendy v podnikání, speciální číslo (2/2019) vědeckého časopisu Trendy v podnikání (ISSN 18050603), zaměřené na prezentaci výsledků projektu TAČR realizovaných $v$ roce 2019 a výzkumu voblasti rozvoje koncepce Průmysl 4.0 a Společnost 4.0. Dostupné květen 20, 2020, z https://www.trendypodnikani.cz/.

Konference (aktivní účast Ing. Marie Černá, Ph.D.)

V období 09/2019 se uskutečnila propagace projektu TAČR a jeho dílčích výsledků v Rakousku, na OÖ ZUKUNFTSFORUM 2019, prezentován poster.

\section{Workshopy}

duben 2019

Workshop řešitelského týmu projektu TAČR se zástupci externích aplikačních garantů projektu. Místo konání - VŠTE v Českých Budějovicích (13 účastníků).

leden 2020

Taušl Procházková, P. (2020). Zpráva z workshopu č. 1 „Adaptace sektoru znalostně náročných služeb na podmínky Společnosti 4.0. Dostupné březen 31, 2020, z https://azis.zcu.cz. Místo konání Západočeská univerzita, Fakulta ekonomická (32 účastníků). 


\section{Dotazníkové šetření}

V období 04-11/2019 byl proveden dotazníkový průzkum u malých a středních podniků $v$ sektoru znalostně náročných služeb - zpráva o dotazníkovém průzkumu zveřejněna na webových stránkách projektu TA ČR https://azis.zcu.cz.

\section{Řízené rozhovory}

V období 06-11/2019 byly provedeny řízené rozhovory s vlastníky nebo vedoucími manažery malých a středních podniků $v$ sektoru služeb - zpráva o řízených rozhovorech zveřejněna na webových stránkách projektu TA ČR https://azis.zcu.cz. 


\section{DEDIKACE}

Metodika byla zpracována za finanční podpory Technologické agentury ČR, programu Éta, jako výstup projektu č. TL02000136 „Adaptace sektoru znalostně náročných služeb na podmínky Společnosti 4.0“ (https://azis.zcu.cz, 2019-2021).

\section{Jména recenzentů}

Doc. Ing. Pavel Kopeček, CSc., Západočeská univerzita v Plzni, Fakulta strojní, kopecek@kpv.zcu.cz Ing. Monika Březinová, Ph.D., Jihočeská univerzita v Českých Budějovicích, Zemědělská fakulta, brezina@zf.jcu.cz

\section{Kontakt na osobu předkladatele metodiky}

Prof. Ing. Lilia Dvořáková, CSc.

Západočeská univerzita v PIzni, Fakulta ekonomická

Univerzitní 8, 30100 Plzeň

+420602120989

Idvorako@kfu.zcu.cz

https://azis.zcu.cz 


\section{J PROHLÁŠENÍ PŘEDKLADATELE METODIKY}

Předkladatel Metodiky prohlašuje, že zpracovaná metodika nezasahuje do práv jiných osob z průmyslového nebo jiného duševního vlastnictví.

Předkladatel Metodiky adaptace malých a středních podniků v sektoru služeb na implementaci principů, postupů, metod a nástrojů Společnosti 4.0 potvrzuje, že Metodika je uveřejněna a bezplatně přístupná $\mathrm{k}$ využití všem externím aplikačním garantům projektu a malým a středním podnikům $v$ sektoru služeb a dalším zájemcům z hospodářské praxe a akademické sféry na webových stránkách projektu https://azis.zcu.cz. 


\section{K PŘíLOHY}

Př́loha 1 Plátno (schéma) podnikatelského modelu

Príloha 2 Lean Canvas

Příloha 3 Příklady školení/seminářů poskytujících návod na digitalizaci podnikových procesů 
Př́loha 1 Plátno (schéma) podnikatelského modelu

SCHÉMA PODNIKATELSKÉHO MODELU

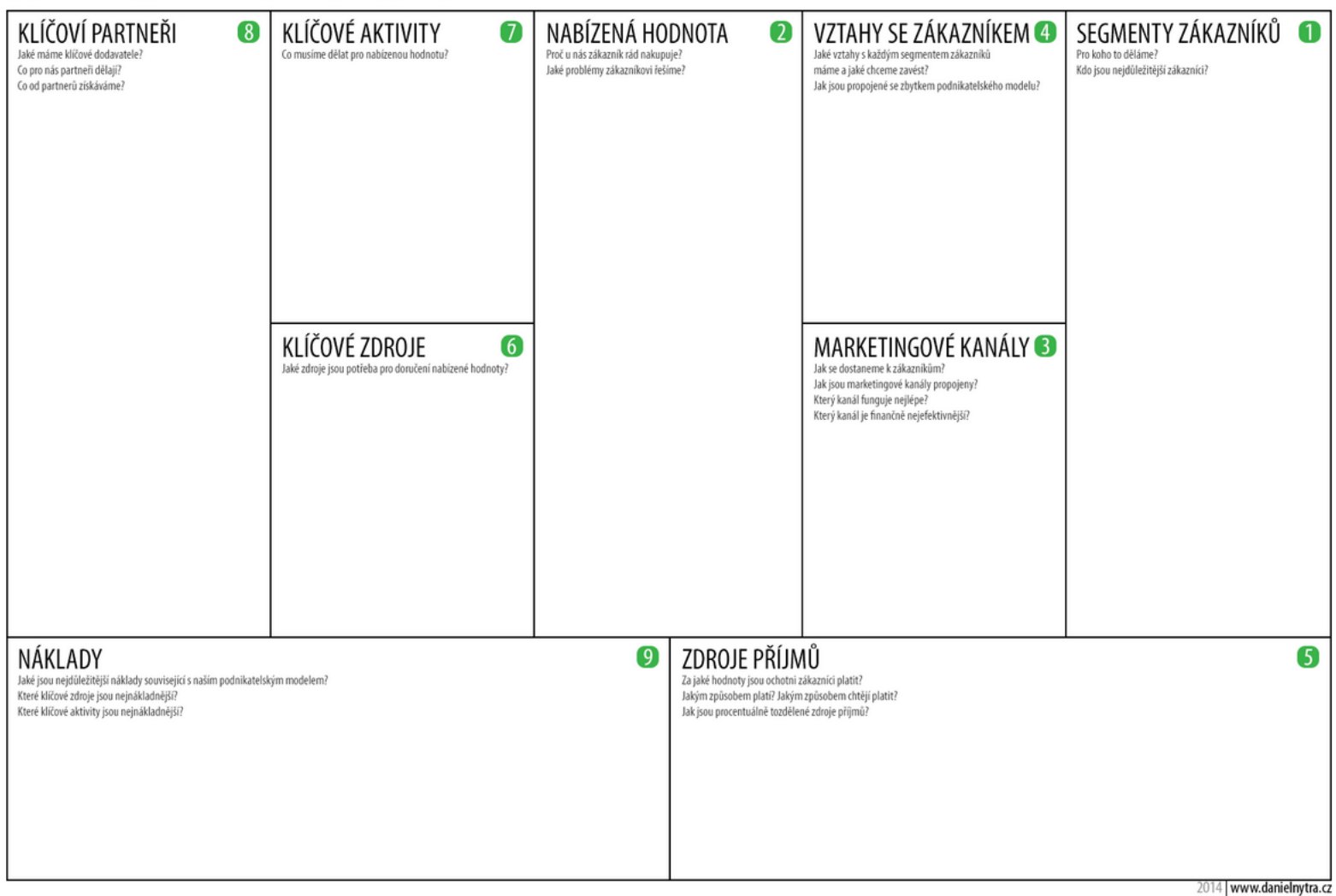

PLÁTNO PODNIKATELSKÉHO MODELU

Polička plátna vyplňujte $v$ uvedeném pořadí.

Plátno (schéma) Ize stáhnout z

https://www.danielnytra.cz/zdarma-schema-podnikatelskeho-modelu/, doporučujeme pro vyplňování vytisknout ve formátu A3 na šířku

Videoprezentace - návody $\mathrm{k}$ vyplnění:

Business Model Canvas Explained:

https://www.youtube.com/watch?v=qoaozmtlp5s

Osterwalder explaining the Business Model Canvas in 6 Minutes:

https://www.youtube.com/watch?v=rpfil-1tvlw 
Př́loha 2 Lean Canvas

\section{Lean Canvas}

Podnikatelský plán na jedné stranẽ papiru Online kurz zdarma na www.leancanvas.cz

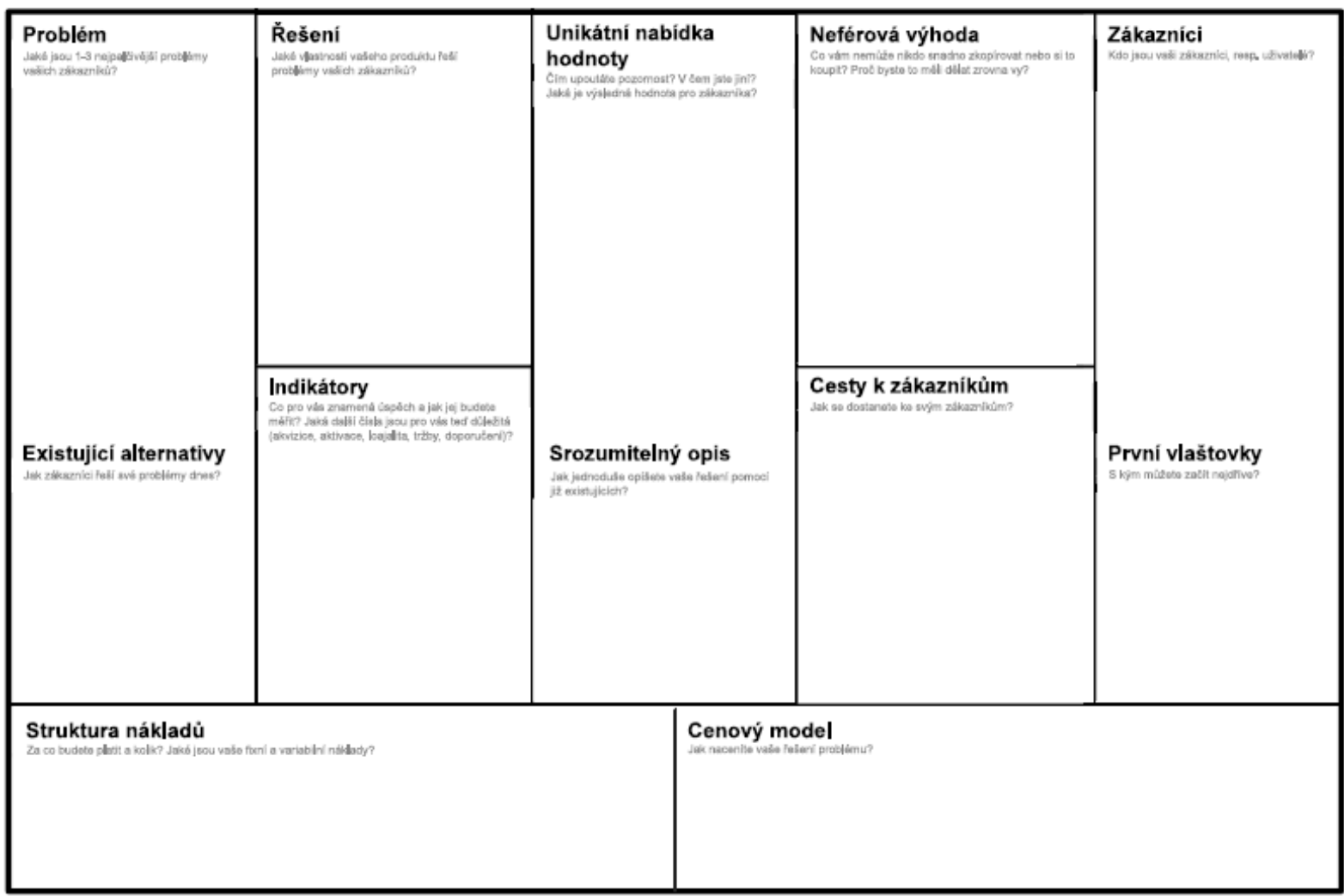

Lean Canvas vytvoril Ash Maurya na záldado Business Model Canvasu, je distribuován pod licenci CC BY-SA 3.0. PṬelożil Jan Vesely a Petra Hájková.

Plátno (schéma) Ize stáhnout z

https://cdn.dobrokurzy.cz/static/leancanvas/LeanCanvasCZ-v20150709.pdf;

tento soubor je $v$ editovatelném pdf formátu. Pro tisk doporučujeme vytisknout ve formátu A3 na šírku.

Lean Canvas - Online kurz za dobrý skutek:

https://www.leancanvas.cz/ 
Př́loha 3 Příklady školení/seminářů poskytujících návod na digitalizaci podnikových procesů (semináře pořádané v 1.- 5. měsíci roku 2020)

\begin{tabular}{|c|c|c|c|}
\hline $\begin{array}{l}\text { Téma } \\
\text { školení }\end{array}$ & Školící agentura & Stručná náplň & $\begin{array}{l}\text { Průměrná } \\
\text { finanční } \\
\text { náročnost } \\
\text { Kč/účastník }\end{array}$ \\
\hline $\begin{array}{l}\text { Digitalizace } \\
\text { firemních } \\
\text { procesů }\end{array}$ & $\begin{array}{l}\text { ictPRO } \\
\text { https://www. } \\
\text { skoleni-softskills.cz/ } \\
\text { kurz/Digitalizace- } \\
\text { firemnich-procesu- } \\
\text { DFP.aspx }\end{array}$ & $\begin{array}{l}\text { Zavádění nástrojů Průmyslu } 4.0 \text { do firmy - } \\
\text { Identifikace přiležitostí pro nasazení nástrojů } \\
\text { Průmyslu 4.0. Jednotlivé nástroje Průmyslu } \\
4.0 \text { - Senzorika, Sběr dat, Vizualizace. } \\
\text { Softwarová integrace - Digitální průvodka, } \\
\text { optické systémy rozpoznávající kvalitu. } \\
\text { Prípadové studie digitalizace firemních } \\
\text { procesů. Příklady z praxe, modelové situace. }\end{array}$ & 7900 \\
\hline $\begin{array}{l}\text { Digitalizace } \\
\text { účetnictví }\end{array}$ & $\begin{array}{l}\text { Kursy.cz } \\
\text { https://www.kursy. } \\
\text { cz/konference- } \\
\text { digitalizace- } \\
\text { ucetnictvi-2020- } \\
\text { productskdig/?utm_- } \\
\text { source=ENDU\&utm_- } \\
\text { medium=enl\&utm_- } \\
\text { campaign=ENDU- } \\
\text { 2020- } \\
\text { 18\&utm_content=EN } \\
\text { DU-welcome- } \\
\text { 2\&uid=\%5B\%5Buid\% } \\
\text { 5D\%5D\&e=\%5B\%5Be } \\
\text { \%5D\%5D\&contract= } \\
\text { \%5B\%5Bcontract\%5 } \\
\text { D\%5D\&wa=WWW20 } \\
\text { E3\%20DU\&odkud=E } \\
\text { NDU }\end{array}$ & $\begin{array}{l}\text { Provázání účetních IS (elektronické } \\
\text { dokumenty vs. listinná forma účetních } \\
\text { záznamů), náležitosti elektronických účet. } \\
\text { a daň. dokladů, opravy, přenášení účetních } \\
\text { záznamů, správný příjem e-záznamů, jejich } \\
\text { úschova a archivace, oběh elektronických } \\
\text { faktur a nastavení procesů ve firmě. Nástroje } \\
\text { pro automatické vyčítání údajů z faktur } \\
\text { a další možnosti automatizace. Automatizace } \\
\text { při zpracování účetnictví klienta účetní } \\
\text { kanceláře po jednotlivých fázích a s využitím } \\
\text { jednotlivých aplikací. Poskytování účetních } \\
\text { aplikací na dálku, tzv. outsourcing IT, } \\
\text { využívání telekomunikačních technologií. }\end{array}$ & 4990 \\
\hline $\begin{array}{l}\text { Elektronická } \\
\text { komunikace } \\
\text { se státní } \\
\text { správou }\end{array}$ & $\begin{array}{l}\text { 1. VoX a.s. } \\
\text { https://www.vox.cz/ } \\
\text { danove-a-ucetni- } \\
\text { kurzy/kurz-jak- } \\
\text { elektronicky- } \\
\text { komunikovat-se- } \\
\text { statni-spravou- } \\
\text { nejen-pro-ucetni-a- } \\
\text { danove-pracovniky- } \\
\text { 0001.htm }\end{array}$ & $\begin{array}{l}\text { Způsoby elektronické komunikace se } \\
\text { správcem daně a dalšími orgány veřejné } \\
\text { moci (ČSSZ, zdravotní pojištovny ap.), ale } \\
\text { i v soukromoprávním styku. Požadavky na } \\
\text { elektronické písemnosti, jejich vystavování, } \\
\text { odesílání, přijetí i ukládání. Zachování } \\
\text { věrohodnosti a průkaznosti digitálních } \\
\text { dokumentů. Rizika při využívání } \\
\text { informačních technologií. }\end{array}$ & 2390 \\
\hline
\end{tabular}




\begin{tabular}{|l|l|l|l|}
\hline $\begin{array}{l}\text { Páteř pro } \\
\text { digitalizaci } \\
\text { vašeho } \\
\text { podniku } \\
\text { (webinář) }\end{array}$ & $\begin{array}{l}\text { Digitální továrna.cz } \\
\text { https://www.plm.au } \\
\text { tomation.siemens. } \\
\text { com/global/cz/webi } \\
\text { nar/digitalni- } \\
\text { pater/67788 }\end{array}$ & $\begin{array}{l}\text { Vybudujte vlastní digitální páteř, která } \\
\text { kromě rychlejší a efektivnější formy práce } \\
\text { přinese propojení celého výrobního podniku } \\
\text { do jednoho celku. } \\
\text { Digitální páteř: šetří náklady na provozování } \\
\text { existujících a nových systémů, zjednodušuje } \\
\text { jejich správu a údržbu, tvoří pevný základ pro } \\
\text { budoucí rozvoj podnik, šetř́ čas při } \\
\text { komunikaci a zamezuje chybám. }\end{array}$ & Zdarma \\
\hline $\begin{array}{l}\text { Jak } \\
\text { digitalizovat } \\
\text { business } \\
\text { (webinář) }\end{array}$ & $\begin{array}{l}\text { Digiskills.cz } \\
\text { https://www.digiskil } \\
\text { Is.cz/blog/zaznam- } \\
\text { webinare-jak- } \\
\text { digitalizovat-byznys }\end{array}$ & $\begin{array}{l}\text { Jaký je stav digitalizace v současném světě, } \\
\text { která odvětví jsou v digitalizaci napřed } \\
\text { a oblasá zaostávají, v jakých odvětvích } \\
\text { aplikace jsou dostupné a můžou vám } \\
\text { s digitalizací pomoci, kde s digitalizací začít, } \\
\text { jaké jsou nejnovější trendy a na co by se } \\
\text { každá firma měla zaměřit. }\end{array}$ & Zdarma \\
\hline
\end{tabular}

